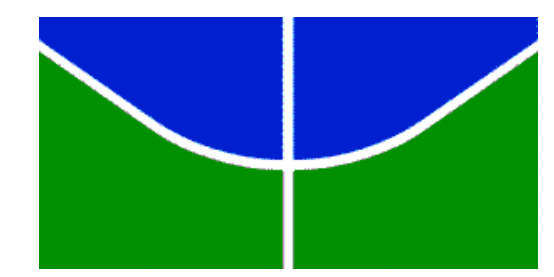

UNIVERSIDADE DE BRASÍLIA

INSTITUTO DE PSICOLOGIA

DEPARTAMENTO DE PSICOLOGIA CLÍNICA

PROGRAMA DE PÓS-GRADUAÇÃO EM PSICOLOGIA CLÍNICA E CULTURA

ANA PAULA MORAIS

O ÍNDICE DE INABILIDADE SOCIAL E A TENDÊNCIA ANTISSOCIAL: CONTRIBUIÇÕES PARA A ANÁLISE PSICOLÓGICA DO FENÔMENO DA VIOLÊNCIA

BRASÍLIA 
O ÍNDICE DE INABILIDADE SOCIAL E A TENDÊNCIA ANTISSOCIAL: CONTRIBUIÇÕES PARA A ANÁLISE PSICOLÓGICA DO FENÔMENO DA VIOLÊECIA

Dissertação apresentada ao Instituto de Psicologia da Universidade de Brasília como requisito à obtenção de Grau de Mestre em Psicologia Clínica e Cultura.

Orientador: Prof. Dr. Ileno Izídio da Costa

BRASÍLIA

2016 


\title{
O ÍNDICE DE INABILIDADE SOCIAL E A TENDÊNCIA ANTISSOCIAL: CONTRIBUIÇÕES PARA A ANÁLISE PSICOLÓGICA DO FENÔMENO DA VIOLÊNCIA
}

\author{
ANA PAULA MORAIS
}

Trabalho realizado no Departamento de Psicologia Clínica do Instituto de Psicologia da Universidade de Brasília, para obtenção do título de Mestre em Psicologia Clínica e Cultura.

Banca examinadora

Prof. Dr. Ileno Izídio da Costa
Presidente da Banca - PsiCC/PCL/IP/UNB

Profa. Dra. Sandra Maria Baccara Araújo

Membro Externo - Escola de Magistratura Federal da $1^{\text {a }}$ Região/DF

Profa. Dra. Maria Izabel Tafuri

Membro do Programa - PsiCC/PCL/IP/UNB

Profa. Dra. Sheila Giardini Murta

Membro Suplente - PsiCC/PCL/IP/UNB

Brasília, 12 de Agosto de 2016 
A todas as pessoas que foram vítimas de extermínio social e que agora estão enclausuradas nos depósitos humanos que são as prisões e manicômios judiciários. E a todos que morreram por serem incômodos demais nesta sociedade hipócrita, preconceituosa e vingativa que não aceita o diferente.

Às mulheres e aos homens negros, a todos que lutam para viver sua negritude livre e dignamente. E a todos que morreram apenas por terem a pele negra.

À todas as pessoas que lutam por sua sobrevivência psíquica, muitas vezes consideradas antissociais, que precisam viver nesta sociedade antipessoas. 


\section{Agradecimentos}

À minha mãe, Ana Maria da Conceição, suficientemente boa e grande incentivadora desse passo acadêmico e profissional. Por todo amor e apoio, por segurar minha mão desde sempre e me dar o incentivo e segurança essenciais para o meu desenvolvimento pessoal e profissional. Agradeço por ser a melhor família que tive a sorte de ganhar.

Às refulgentes amigas e psicólogas Bruna Jalles, Fernanda Duarte e Marcella Albo por todo apoio, conselhos e por tentarem transformar o mundo. O suor, as lágrimas e o sangue que derramam em suas vidas profissionais fazem a diferença no mundo. E, sobretudo e principalmente, agradeço pelo amor, que partilhamos há quase uma década.

Às incríveis amigas de longa data Catarine Resende e Larissa Bello por serem irmãs e compartilharem grandes alegrias e tristezas nos últimos 27 anos, por caminharmos juntas e por todo amor.

Ao Ileno, orientador e professor que desde a graduação mostrou novas possibilidades de pensar o sofrimento psíquico e o lugar do psicólogo nesta sociedade caótica. Agradeço pelo incentivo e por ter acreditado em mim, por ser um exemplo no compromisso com aqueles que sofrem e por permitir que estudantes de Psicologia inexperientes e em busca de conhecimento possam construir juntos novas formas de pensar e práticas de cuidado.

À Elisa Walleska, professora e orientadora por me acolher, acreditar em mim, me ensinar e me permitir fazer parte do seu projeto de vida que é o Personna. Agradeço a paciência, o cuidado e a solidariedade desde a graduação e por ser referência no tema violência e na Psicologia Forense. Seu trabalho faz do mundo um lugar melhor, e por isso também agradeço.

Ao Grupo Personna de Estudos, Pesquisas e Intervenções em Criminalidade, Violência, Perversões e Psicopatia, aos antigos e atuais membros com quem pude compartilhar o ideal de um mundo diferente, angústias, medos, vitórias. Grupo onde pude trabalhar com uma das minhas grandes paixões que é o Rorschach e onde aprendi imensamente. 
À todos os colegas da Psicologia com quem estive na Universidade, desde os companheiros com quem entrei em 2007 aos colegas em eventuais disciplinas, por compartilharem o compromisso com a saúde mental e por tantas reflexões, problematizações e desconstruções.

A todos que se dedicam a estudar e propagar a obra de Winnicott em Brasília, em especial a Sandra Baccara, Alba Dezan, Amanda de Oliveira Mota e demais colaboradores por organizarem o curso A Psicanálise de Winnicott, onde pude me encantar pela obra desse fantástico psicanalista e encontrar uma abordagem que verdadeiramente fizesse sentido em minha vida profissional. Agradeço também aos colegas com quem estive neste curso, aos colegas do Grupo de Estudos em Interpretação dos Sonhos e aos professores Tales Ab'Saber, Sandra Tschirner, Irmgard Ferreira, Tereza Oliveira, Sueli Hisada, Afrânio Ferreira, Aldry Sandro Ribeiro e Márcia Mendes pela inspiração e aprendizado.

Aos grandes professores do Instituto de Psicologia com quem aprendi e desaprendi sobre ser psicóloga. Ao professor Balsem Pinelli, que me apresentou o Rorschach; ao professor Marcelo Tavares, que passou grandes ensinamentos sobre prática clínica e intervenções; e à professora Sheila Murta: sua competência profissional, delicadeza comigo desde a graduação e gentileza de me olhar nos olhos, perguntar como eu estava e me escutar nas respostas alegres e tristes me tocam profundamente; sua educação e cuidado foram extremamente importantes nesses anos acadêmicos e são exemplo raro de humanidade no Olimpo que se tornou a Academia.

Ao Programa de Pós- Graduação em Psicologia Clínica e Cultura, por aceitar o projeto deste trabalho. A todos os colegas da Pós, pela coragem e pelas estimuladoras discussões.

À Secretaria do Departamento de Psicologia Clínica da UnB, agradeço pela solicitude e gentileza de Thamiris Rodrigues, Maria Helena e das estagiárias Taís e Larissa.

À Universidade de Brasília, onde cresci pessoal e profissionalmente em meio à sua diversidade de pessoas e ideias. E à CAPES, pelo apoio financeiro durante essa jornada. 
Olhem de novo esse ponto. É aqui, é a nossa casa, isso somos nós.

Nele, todos a quem ama, todos a quem conhece, qualquer um sobre quem você ouviu falar, cada ser humano que já existiu, viveram as suas vidas.

O conjunto da nossa alegria e nosso sofrimento. Milhares de religiões, ideologias e doutrinas econômicas, cada criador e destruidor de civilização (...) viveu aí, num grão de pó suspenso num raio de sol. As nossas posturas, a nossa suposta autoimportância, a ilusão de termos qualquer posição de privilégio no Universo, são desafiadas por este pontinho de luz pálida. O nosso planeta é um grão solitário na imensa escuridão cósmica que nos cerca. Na nossa obscuridade, em toda esta vastidão, não há indícios de que vá chegar ajuda de outro lugar para nos salvar de nós próprios.

Carl Sagan 


\section{Resumo}

Esta reflexão teórico-clínica discute as contribuições da teoria de Winnicott e do método de investigação de Rorschach no que se refere ao fenômeno da violência e às pessoas que cometem atos de violência. Partindo da concepção de que a violência é um fenômeno construído socialmente, observa-se a tentativa de patologizar esse fenômeno e atribuí-lo a sujeitos específicos. A fim de complexificar a análise dos contextos sociais, históricos, econômicos e políticos onde a patologização do fenômeno da violência é feita, foi incluída na discussão uma teoria psicanalítica em que se pudesse apoiar para refletir sobre o aspecto mais pessoal do fenômeno da violência. Winnicott contribui com suas propostas psicanalíticas para o desenvolvimento emocional e para a tendência antissocial. No trabalho forense, a Psicologia, a Psiquiatria e a Psicanálise são chamadas a complementarem decisões jurídicas sobre esses sujeitos considerados antissociais. Avaliações psicológicas, nessa situação, são caminhos privilegiados para se aproximar à subjetividade dos sujeitos. O Método de Rorschach foi incluído como uma possibilidade avaliativa, de forma a se aproximar das características psicológicas sem diagnósticos $a$ priori e contextualizando o sujeito dentro das particularidades de sua história pessoal, em particular através do İndice de Inabilidade Social. O objetivo principal deste trabalho é discutir as características social e relacional do fenômeno da violência, obervando as particularidades psíquicas do sujeito que comete violência e situando-o em um meio ambiente que o transforma e que é transformado por ele. Com isso, buscamos nos aprofundar nas reflexões e práticas no tema da violência e levantar novas possibilidades de avaliação e acompanhamento psicoterapêutico, social e jurídico dessas pessoas.

Palavras-chave: Violência; Winnicott; Tendência antissocial; Rorschach; Ìndice de Inabilidade Social 


\begin{abstract}
This theoretical-clinical reflexion discuss the contributions of Winnicott's theory and the Rorschach Method of investigation in the theme of violence and people who commit violence. Starting from the conception of violence as a social construct phenomenon, the attempt of pathologize this phenomenon and assigning it to specific subjects is observed. Lokking for complexifying the analysis of social, historical, economic and politic contexts where the pathologization of violence is done, was included a psychoanalytic theory where is possible be based to reflect about the most personal side of violence. Winnicott contributes with their psychoanalytic proposals for the emotional development and for the antisocial tendency. In forensic work, Psychology, Psychiatry and Psychoanalysis are called to complement juridical decisions about these subjects adjudged antisocial. In this situation, psychological assessments are a privileged ways to reach the subjectivity. The Rorschach Method has been included in this discution as an assessment possibility, which allows an approach to psychological traits without a priori diagnosis and contextualizing the subject within the particularities of his own personal history, particularly through the Coping Deficit Index. The main aim of this work is discuss social and relational features of violence phenomenon, regarding psychic particularities of who commit violence and locating him an environment that change him and is changed by him. Thus, we seek to deepen the concepts and practices in violence theme and rise new possibilities of psychotherapeutic, social and juridical attendance for these people.
\end{abstract}

Keywords: Violence; Winnicott; Antisocial Tendency; Rorschach; Coping Deficit Index. 


\section{Sumário}

$\begin{array}{ll}\text { Dedicatória } & \text { i }\end{array}$

Agradecimentos $\quad$ ii

Epígrafe

Resumo

Abstract vi vi vis

Apresentação $\quad 8$

$\begin{array}{ll}\text { Introdução } & 11\end{array}$

$\begin{array}{ll}\text { Capítulo 1: A patologização de fenômenos sociais } & 18\end{array}$

1.1.Violência enquanto fenômeno social 19

1.2. Processo de patologização da violência 31

Capítulo 2: As contribuições winnicottianas para as elaborações sobre o sujeito antissocial 49

2.1. O desenvolvimento emocional 50

2.2. A tendência antissocial 60

Capítulo 3: A tentativa de patologização da tendência antissocial e outras $\begin{array}{ll}\text { possibilidades diagnósticas } & 75\end{array}$

3.1. O diagnóstico em contextos de violência 76

3.2. O Método de Rorschach e suas outras possibilidades de avaliação

Psicológica

Capítulo 4: O Índice de Inabilidade Social e a Tendência Antissocial:

um olhar de base winnicottiana sobre o fenômeno da violência 106

$\begin{array}{lr}\text { Considerações finais } & 122\end{array}$

$\begin{array}{lr}\text { Referências bibliográficas } & 128\end{array}$ 


\section{Apresentação}

Realizar o mestrado surgiu mais como algo que eu poderia fazer do que qualquer outra explicação, então o conseguir de fato esteve sempre em questão e sob duras dúvidas pessoais. Provavelmente por essa razão houve um grande momento de autoconhecimento entre o final da graduação e o início do mestrado. Desde o final da graduação todos que eu conhecia me perguntavam quando eu iria começar o mestrado, como se esse fosse um caminho lógico e natural na vida acadêmica. Entretanto sempre tive claro que só iria começar caso esse próximo passo fizesse verdadeiramente sentido para mim, e isso aconteceria quando estivesse pronta. Fez sentido para mim por razões diferentes das que eu imaginei e só pode acontecer depois de estar com pessoas que sofriam imensamente em condições desumanas em celas afastadas da sociedade; e por eles tentei me convencer de que estava pronta.

Fundamental no meu aprimoramento profissional e no meu amadurecimento como pessoa foi participar do Grupo Personna. Foi bastante enriquecedor presenciar os ideais de mudança social e cuidado com o outro da professora Elisa Walleska e do professor Ileno e descobrir que também ansiava por colocar meu saber e fazer profissional a serviço de mudanças pessoais e sociais tão importantes na vida de pessoas que tinham que responder judicialmente por algo que fizeram. A possibilidade de conhecer de perto outra forma de atuação profissional que não a clínica tradicional aconteceu tardiamente em meu percurso acadêmico, mas em perfeita sincronia com outra descoberta essencial no meu caminho profissional e pessoal: Donald Winnicott. Já fora da academia pude participar de um curso de extensão sobre a teoria winnicottiana, organizado pela professora doutora Sandra Baccara e a mestre Amanda de Oliveira. Ali encontrei a psicanálise inovadora que tanto busquei e que deu sentido aos meus estudos acadêmicos prévios, uma teoria que me 
permitiria continuar com os questionamentos, reflexões e trabalhos de forma mais embasada e aprofundada.

O Grupo Personna dedica-se a estudos, pesquisas e intervenções na área de criminalidade, violência, perversão e "psicopatia". De forma crítica, busca os diversos fatores que permitem a ocorrência da violência e sua manutenção, dialogando com a psicologia, psicanálise, sociologia, antropologia, direito, economia, serviço social, pedagogia e segurança pública. O olhar crítico para o tema inspira a produção de conhecimento e a abertura para esse campo de trabalho, e a difícil realidade das pessoas em conflito com a lei e que estão em sofrimento psíquico não nos deixa descansar na tentativa de mudar essas realidades, sempre orientados pelos direitos humanos, a ética e o cuidado.

Fazendo parte do Grupo Personna, tive a oportunidade de participar da avaliação de pessoas que estavam cumprindo medida de segurança na Ala de Tratamento Psiquiátrico do Distrito Federal. Especificamente utilizando o Método de Rorschach, que fazia parte de uma avaliação mais ampla e aprofundada que buscava informações pessoais, médicas, psicológicas, familiares, sociais e judiciais sobre aquelas pessoas, a fim de fazer um trabalho sério e consistente na tentativa de auxiliar no tratamento e processo jurídico. Dos 11 Rorschachs realizados por mim em 2013 na ATP, a maioria mostrava características e variáveis semelhantes, o que chamou minha atenção. Seis protocolos de Rorschach mostravam o Índice de Inabilidade Social positivo que, de forma resumida, tem em sua base relação com controle do estresse e relações interpessoais.

Isto me levou a diversas indagações sobre as condições psíquicas com que os internos chegaram à Ala de Tratamento, a forma como era realizado o tratamento que presume-se que é feito, como o sistema carcerário brasileiro tem cuidado dos presos e na dificuldade de recuperação de pessoas que muitas vezes possuem uma demanda psicológica além do processo judicial que enfrentam. Refletindo sobre como as prisões no 
Brasil são feitas para excluir, calar e torturar, foi imediata a necessidade de buscar as relações desse sistema com os traços psicológicos de tolerância ao estresse e dificuldades nas relações interpessoais que os internos apresentaram. Além disso, a certeza de que pessoas que passaram por episódios de violência não são a encarnação do mal pura e simplesmente motivou a busca por outras possibilidades de aproximação à subjetividade dessas pessoas e novas formas de compreender os fenômenos de forma micro e de forma macro. 


\section{Introdução}

Existem várias abordagens ao tema agressividade nas ciências humanas e da saúde, desde aquelas que a buscam em uma localização cerebral até aquelas que a igualam à violência. Este estudo segue por um caminho que compreende que tanto o amor quanto o ódio coexistem no psiquismo humano, sem uma valoração moral quanto a um ser bom e o outro ser ruim independentemente. Um caminho que procura entender as vivências subjetivas dos seres humanos dentro de um contexto pessoal, familiar, social, cultural e político.

Base fundamental é a obra de Donald Winnicott, pediatra e psicanalista inglês que teve sua clínica e seus escritos influenciados por suas experiências nas Guerras Mundiais. Seu trabalho com crianças direcionou o olhar para as relações mãe-bebê, para as privações pelas quais passaram as crianças evacuadas dos locais de batalha e abriu um novo caminho para se pensar o desenvolvimento emocional desde a primeiríssima infância. Pensar a integração psíquica dentro de um ambiente facilitador do potencial para o amadurecimento com o qual nascemos foi uma inovação na psicanálise, mostrando a importância das primeiras relações e cuidados na formação da personalidade.

A teoria da tendência antissocial, que baseará esse estudo, parte de uma compreensão da agressividade proposta por Winnicott que a diferencia da violência. A agressividade relaciona-se ao movimento corporal, ao estabelecimento do que é ou não self, revelando uma boa integração psíquica. Paradoxalmente, a agressividade é um componente psíquico que se tenta esconder, disfarçar e atribuir a agentes externos. Sua manifestação pode se dar na relação com o externo, mas olhar para a constituição interna também soma às explicações.

A tendência antissocial, que pode ser encontrada em todas as idades e estruturas ou funcionamentos psíquicos, não é uma categoria diagnóstica. A tendência antissocial é um 
movimento do sujeito que chama o ambiente a comparecer, a cuidar dele, após a deprivação vivida. O conceito de deprivação é essencial para essa forma de ser antissocial, e refere-se à perda de algo bom que foi positivo na experiência em tenra idade e que foi retirado por um tempo maior do que a criança poderia manter a lembrança da experiência. O trauma e a persistência da situação traumática estão diretamente ligados a esse resgate do que se perdeu representado na atitude antissocial.

Essa inovadora visão da manifestação antissocial, e seus comportamentos como roubo, mentira e destrutividade, introduzida por Winnicott (1956) inclui a esperança do sujeito no resgate do que foi perdido e na reparação da falha ambiental que originou o trauma. Sobre essa expressão de esperança o psicanalista alerta que:

Vemos constantemente o momento de esperança ser desperdiçado, ou desaparecer, por causa da má administração ou intolerância. É outro modo de dizer que o tratamento da tendência antissocial não é a psicanálise, mas administração, uma conduta no sentido de ir ao encontro do momento de esperança e corresponder a ele. (pg. 139)

A psicologização e a psiquiatrização da tendência antissocial parecem bons exemplos de intolerância ao chamado do ambiente para a dramatização da destrutividade insuportável. A transformação de uma defesa ou de uma forma de ser no mundo em um transtorno mental incorre na falta de profundidade com que a expressão de um sofrimento psíquico é abordada, e deixa subentendido que a questão é ontogênica, passível de cura e que determinadas pessoas estão aptas a curar. Para além do funcionamento antissocial, este é um problema da supervalorização dos diagnósticos.

O Manual Diagnóstico e Estatístico dos Transtornos Mentais - DSM-V da Associação Psiquiátrica Americana traz o que poderia ser o correlato psiquiátrico da tendência antissocial introduzida aqui. É o Transtorno de Personalidade Antissocial, caracterizado como um padrão global de desrespeito e violação dos direitos alheios, que ocorre desde os 15 anos, indicado por, no mínimo, três dos seguintes critérios: 1) incapacidade de adequar-se às normas sociais; 2) propensão para enganar; 3) 
impulsividade ou fracasso em fazer planos para o futuro; 4) irritabilidade e agressividade; 5) desrespeito irresponsável pela segurança própria ou alheia; 6) irresponsabilidade consistente; 7) ausência de remorso. Além disso, há a idade mínima de 18, a ressalva de precisar haver transtorno da conduta antes dos 15 anos e a ausência de comorbidade com Esquizofrenia ou Episódio Maníaco (APA, 2013)

Os critérios do DSM focam no aspecto comportamental que pode ter por trás um sofrimento psíquico, sendo assim, ainda está longe de alcançar as peculiaridades psicodinâmicas da tendência antissocial proposta por Winnicott, por exemplo. A psicopatia, de acordo com Hare (1993), prevê padrões interpessoais e psicodinâmicos e também atos antissociais, dois componentes que podem ocorrer de forma separada. $\mathrm{O}$ Psychopathy Checklist Revised (PCL-R) proposto por ele é uma escala que busca avaliar o grau de risco de reincidência à criminalidade por meio da identificação de impulsividades e instabilidades. Também é problemático porque os sintomas de psicopatia determinados por Hare e que baseiam a escala são facilmente identificados e relatados por pessoas "normais", como superficialidade, egocentrismo, falta de empatia, manipulação, pobre controle comportamental, falta de responsabilidade, necessidade de excitação entre outros.

Tanto a PCL-R quanto os critérios do DSM são amplamente utilizados por psicólogos e psiquiatras para realizar diagnóstico. Entretanto é imperativo sinalizar que a busca por um diagnóstico e uma avaliação psicológica são procedimentos bastante diferentes, em objetivos e profundidade. É válido que se utilizem instrumentos e técnicas a fim de se compreender mais detalhadamente o funcionamento psíquico de um sujeito, porém isso deve ser feito com o intuito de ajudá-lo, de acolher seu sofrimento, e não com a finalidade em si mesma de se chegar a um termo diagnóstico. Este é um cuidado ético, expresso inclusive no Código de Ética do Psicólogo, como traz em um de seus princípios fundamentais: O psicólogo trabalhará visando promover a saúde e a qualidade de vida das 
pessoas e das coletividades e contribuirá para a eliminação de quaisquer formas de negligência, discriminação, exploração, violência, crueldade e opressão (CFP, 2005).

Ética e tecnicamente, é importante situar o psicodiagnóstico, já que os psicólogos clínicos são frequentemente chamados a realizá-lo. O psicodiagnóstico é uma modalidade de avaliação psicológica realizada com objetivos clínicos. É um processo que busca identificar forças e fraquezas no funcionamento psicológico, focando a presença ou ausência de uma psicopatologia de acordo com os parâmetros dos limites da variabilidade normal (Cunha, 2000). Percebe-se que apesar da sua utilidade e amplo uso clínico, o psicodiagnóstico pode ser limitado dependendo do caso em questão. Caso o objetivo seja uma compreensão mais aprofundada que não esteja preocupada com o estabelecimento de um diagnóstico, esta forma de psicodiagnóstico mais inflexível não é a melhor opção. A avaliação psicológica mais ampla permitiria uma maior adaptação e flexibilidade por não ter foco na patologia, podendo-se lançar mão de técnicas e instrumentos variados e estar aberto para o que os dados obtidos têm a informar sobre o sujeito.

Um sofisticado e amplamente reconhecido instrumento de investigação da personalidade é o Método de Rorschach. Ele começou a ser desenvolvido por Hermann Rorschach em 1911 e em 1921 o psiquiatra e psicanalista suíço publicou a monografia Psicodiagnóstico: um teste diagnóstico baseado na percepção, onde eram relatadas as conclusões dos estudos e experimentos com as pranchas por ele elaboradas. O método consiste em 10 pranchas com manchas de tinta sem forma definida às quais se deve dizer o que elas poderiam ser e explicar a percepção feita da mancha. Por ser um estímulo desestruturado e não ser dito o que e como será avaliado, as pessoas que realizam essa tarefa têm pouco ou nenhum controle sobre suas respostas que dão e intenção de manipulação (Weiner, 2000). 
Para além de um teste projetivo, o Rorschach é um método de investigação que gera dados que identificam diversos aspectos distintos tanto da estrutura (sentimentos e pensamentos atuais e disposições mais permanentes na conduta) quanto da dinâmica (necessidades, atitudes, conflitos e preocupações subjacentes que influenciam pensamentos, sentimentos e comportamentos em momentos específicos) da personalidade. Além disso, também atende à demanda de psicodiagnóstico e diagnóstico diferencial. Nesse sentido, o Rorschach sistematizado por Exner permite uma percepção diferenciada da subjetividade, por meio da investigação do funcionamento do sujeito em áreas como processos cognitivos, relações interpessoais, autopercepção, traços afetivos e controle e tolerância ao estresse (Weiner, 2000).

Uma das interpretações possíveis dos dados levantados no Rorschach é pelo Sistema Compreensivo de Exner (Exner, 1999). Esse Sistema Compreensivo o transforma em um instrumento científico, devido aos estudos normativos e de validação realizados sob essa abordagem. Ademais, permite considerar o Rorschach como um método que transcende os pontos de vista teóricos e não vê-lo como um teste vinculado a uma teoria específica, abrindo espaço para que seus dados sejam interpretados de acordo com o referencial teórico que se preferir. Esse sistema organiza o funcionamento psíquico em 8 agrupamentos de variáveis relacionadas com uma série de traços psicológicos, e essa organização facilita a interpretação dos dados e cobre as grandes áreas da vida do sujeito.

\section{Justificativa}

A violência é um fenômeno social, tanto em sua gênese quanto em seu impacto social. Limitá-la a um sujeito e analisá-la de forma superficial pode dificultar a compreensão da sua complexidade de fatores e multideterminações. Muitos são os esforços de diversas áreas do conhecimento para determinar as repercussões econômicas e políticas 
da violência (Godisi, 2004), o que soma na discussão sobre as formas de diminuição do fenômeno. Inúmeros também são os trabalhos na Psicologia que falam dos efeitos psicológicos em pessoas que sofreram violência ou pesquisas que buscam as origens da violência. Os passos na direção de uma compreensão mais ampla da violência e mais aprofundada da perspectiva de quem comete violência já começaram a ser dados (Costa, 2015). Entretanto ainda há muito a ser feito. Academica e socialmente, é urgente pensar em novas formas de abordar o tema. Foi colocada em perspectiva neste trabalho aqueles que cometem violência pois intervenções com essas pessoas prestam assistência ao sofrimento que elas vivem e podem interromper o ciclo da violência.

A ideia inicial é a de que se o Índice de Inabilidade Social analisado no Rorschach ressalta os traços psicológicos como a capacidade de controle e tolerância ao estresse juntamente com as relações interpessoais, e os comportamentos antissociais têm origem e consequência nas relações interpessoais podendo ser minimizados fortalecendo controle e

tolerância, então o Índice de Inabilidade Social pode auxiliar no acompanhamento psicoterapêutico, social e jurídico da tendência antissocial. Essa ideia, que relaciona o Índice de Inabilidade Social do Rorschach e a tendência antissocial de Winnicott foi a base para a construção deste trabalho.

Objetivos

O objetivo principal deste trabalho é discutir as características sociais e relacionais do fenômeno da violência, observando as particularidades psíquicas do sujeito que comete violência e situando-o em um meio ambiente que o transforma e que é transformado por ele. Os objetivos específicos são: 
- Refletir sobre a patologização da violência, considerando que esta não é resultado apenas de características pessoais, mas também de aspectos familiares, sociais, culturais e políticos;

- Discutir a teoria de Winnicott como uma inovação na discussão sobre "psicopatia", fugindo do senso comum sobre o assunto e buscando fundamentação teórica em uma teoria psicológica; e

- Sugerir que o Método de Rorschach seja utilizado para investigar possíveis traços psicológicos e problemas relacionais que expliquem o comportamento violento, sem, entretanto, utilizar o psicodiagnóstico para reforçar estereótipos e preconceitos. 


\section{Capítulo 1: A patologização de fenômenos sociais}

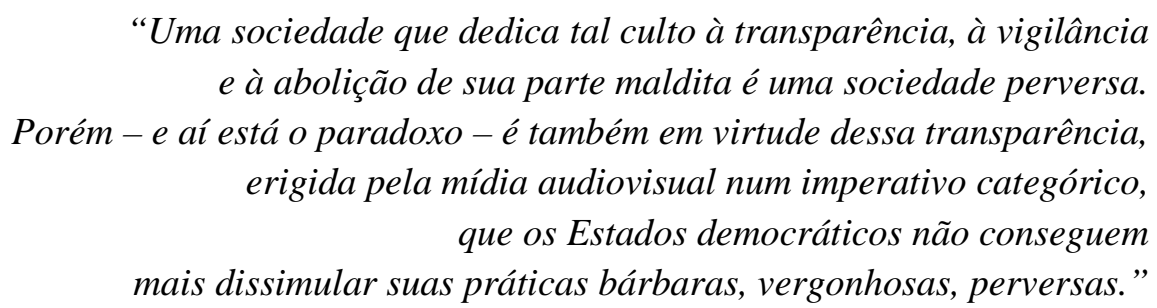

Elisabeth Roudinesco (2008)

Os fenômenos sociais, queiramos ou não, são forças que mudam os cursos de nossas vidas enquanto indivíduos, enquanto sociedade e enquanto humanidade. Somos nós que os criamos e é em nós que eles repercutem. De tempos em tempos um ou outro fenômeno social ganha mais atenção em nossas reflexões e discussões, porém talvez a violência seja um dos grandes focos de nossos olhares de forma continuada. Obviamente existem várias especificidades e tipos de violência, como a física, a sexual e a psicológica. Ademais, qualquer pessoa está sujeita a ela, como crianças, mulheres, homens e idosos. Além também de pessoas em sofrimento psíquico, pessoas que cometem violência e pessoas em privação de liberdade, por mais esquecidas que elas ainda possam ser.

Pode-se considerar uma unanimidade, já há algum tempo (Zaluar, 1999), que a violência não é simplesmente natural à condição humana ou que possui raízes genéticas. Segundo Minayo (1999), ela é um fenômeno biopsicossocial complexo e dinâmico, mas que tem seu espaço de criação e desenvolvimento na vida em sociedade. Segundo a Organização Mundial da Saúde, violência pode ser definida como o uso de força física ou poder em forma de ameaça ou prática, contra si, um outro, grupo ou comunidade que resulte ou possa resultar em sofrimento, morte, dano psicológico, desenvolvimento prejudicado ou privação (Dahlberg \& Krug, 2006). Obviamente essa definição não é absoluta, visto que violência é um termo bastante polimorfo. Podemos complexificar essa 
definição com a ideia de Zaluar (1999) de que é a percepção do limite ultrapassado, perturbação e sofrimento causado que caracterizará uma ação como violenta, percepção essa que muda cultural e historicamente.

Diante dessas propostas de conceituação, para melhor compreensão deste trabalho, a violência a que nos referimos é uma construção social de desrespeito ao próximo que lhe causa sofrimento e que pode ter como agente um indivíduo, um grupo de pessoas, instituições e o próprio Estado.

\subsection{Violência enquanto fenômeno social}

A compreensão da violência como uma construção, e portanto um fenômeno social, se dá a partir de considerações sobre onde ela surge e para onde ela se volta. Podemos entender sem grandes dificuldades que a violência não surge em meio ao nada, ela se inicia em um contexto. E ela precisa ser atuada, é preciso que uma ação tenha características específicas para ser considerada violenta; sendo assim, seres humanos são essenciais para o fenômeno violência. A violência está onde as pessoas estão, onde elas moram, trabalham, sentem e vivem. Com isso não pretendemos dizer que a violência é fenômeno obrigatório da sociedade, mas sublinhar que para compreendê-la é fundamental olhar para o contexto político, econômico, religioso, cultural, institucional e relacional onde a violência acontece, e não denominá-la como uma entidade viva por si só.

Se é construída por nós enquanto sociedade, as consequências da violência também recaem sobre nós. E elas são dos mais diversos tipos, como angústia pessoal, medo social, sofrimento psíquico, mudanças de comportamento, acontecimentos familiares decisivos, prejuízos laborais, diminuição da qualidade de vida, danos nas relações interpessoais, insegurança quanto às normas sociais e violações dos direitos humanos. A abrangência dessas consequências não se limita aos envolvidos em situação de violência, mas se 
estende a todas as comunidades e grupos sociais próximos. Então a compreensão, manejo e prevenção da violência tem dupla importância: diminuir os impactos econômicos e sociais e permitir um cuidado diferenciado com os indivíduos envolvidos em situação de violência.

Segundo Godsi (2004), a globalização do mercado tem levado a uma desigualdade de condições materiais em níveis nacionais e internacionais e está distorcendo os panoramas político e ideológico de nossa sociedade. As políticas do mercado estão moldando nossas estruturas culturais e não só como vemos e nos sentimos em relação aos outros, mas também como compreendemos nossas relações mais próximas e mais distantes. Pode parecer impossível e chocante, mas os novos contextos econômicos globais acabam por influenciar nossas relações interpessoais, e consequentemente dificuldades nessas relações, por estabelecerem novos papeis no cenário econômico.

A ideia de que o mundo é um grande palco para trocas comerciais faz de cada um de nós atores econômicos, que precisam comprar, vender e capitalizar até as coisas mais simples da vida. Um mercado globalizado garante que ninguém escape a essa ideia e exige que todos que possam colaborar para o desenvolvimento econômico participem. Em um contexto onde lucrar e ter são as palavras de ordem, ser alguém que vive em consonância com sua própria essência é um desafio. Então as pessoas se transformam para caberem nos papeis em que precisam se adaptar, e as relações sociais são transformadas junto.

Um breve olhar à história do Brasil possibilita retomar a maneira como fomos nos constituindo como um Estado e mostra as bases políticas, econômicas e sociais do país em que vivemos hoje, o que pode lançar luz à nossa discussão sobre o fenômeno da violência urbana. O Brasil é uma ex-colônia portuguesa que obteve sua independência apenas em 1822 a partir de um regime monárquico. Suas características econômicas e políticas eram, então, a monocultura voltada para a exportação, exploração da força de trabalho escrava de 
negros traficados do continente africano e organização social com rígida hierarquia entre brancos de origem portuguesa, negros escravizados, homens livres sem terras e as populações indígenas (Vicentino \& Dorigo, 2001).

A oligarquia era a base do regime político, onde a dominação era legitimada pela posse de grandes propriedades rurais e aqueles que detinham patrimônios, inclusive a Igreja, se relacionavam por meio de troca de favores e apoio político. Uma forma de política que mostra fraca organização partidária e entraves para a mobilização daqueles em estratos inferiores da hierarquia. Segundo Adorno (2002), essa estrutura, que se manteve por seis décadas (de 1822 a 1889), esses princípios sociais e políticos levaram a uma formação da vida em sociedade que se constitui no parentesco, na indiferenciação de interesses públicos e privados, no estreitamento da vida íntima e grau de intimidade e aprofundamento dos vínculos emocionais.

Este era um cenário de clara dominação de um grupo sobre outros, de pouquíssima participação econômica e política por parte de pessoas menos abastadas e que favorecia violências estruturais das classes dominantes sobre as classes dominadas, onde o uso da força física era amplamente utilizado para subjugar aqueles considerados inferiores, inclusive uma prática legitimada. Uma violência exercida por haver uma segregação social e para manter essa segregação.

A partir de meados do século XIX, a sociedade brasileira passou por transformações que desestabilizaram esse quadro econômico e político. O polo produtivo da monocultura agroexportadora saiu do Nordeste e foi para o Sudeste, a força de trabalho escrava foi substituída por imigrantes europeus contratados e a monarquia deu lugar à república. Ademais, desde 1880 e bem ilustrado na década de 1930, o perfil do país foi lentamente mudando de agroexportador para industrial, o que implica trabalho livre, 
demanda políticas econômicas bem definidas e nos coloca no mercado internacional (Vicentino \& Dorigo, 2001).

Os reflexos sociais dessas transformações a partir da República atingiram diretamente a hierarquia vigente, que foi levando à sociedade de classes caracterizada por um ativo proletariado agora urbano. As desigualdades entre as regiões foram inevitáveis e a concentração de capital pelos produtores de café, proprietários rurais e pela recente classe industrial eram fato. As consequências foram o agravamento das discrepâncias sociais, revoltas no campo e greves nas cidades (Adorno, 2002).

Pode-se perceber que a violência estrutural anterior, e que se manteve e se agravou, gerou uma resposta agressiva da população da época, que massivamente era excluída do círculo político e participava do círculo econômico majoritariamente como atores coadjuvantes para geração de lucro da classe dominante. Essa violência resultante do monopólio legal do uso da força pelo Estado precisa ser incluída nas discussões sobre violências, haja vista que ela está vinculada à falta de acesso a direitos políticos e sociais. E uma sociedade que pretende viver em paz e sem violência não se constituí onde seus membros estão privados de direitos.

Por volta de meados do século XX, o desenvolvimento do parque industrial foi acelerado devido à substituição das exportações durante a Segunda Guerra, a política de subsídios estatais, a regulação das atividades econômicas e o protecionismo à indústria do país. Acompanhado disso vieram o aprofundamento do capitalismo brasileiro, o crescimento econômico, a modernização da infraestrutura tecnológica e urbana e a participação das massas no cenário político. Porém, logo vieram uma grave crise socioeconômica, elevadas taxas de inflação e pouco crescimento econômico, que demandaram dos governos civis abertura econômica, privatizações e inclusão no mercado global (Vicentino \& Dorigo, 2001). 
Desde a década de 1980, avanços industriais e tecnológicos aconteceram. E apesar das carências sociais, a escolarização e a saúde pública mostraram progresso. Mesmo com a crise política e o impeachment do presidente em 1992, a democracia foi mantida e alguns avanços podem ser pontuados: transparência governamental, ação de órgãos de vigilância, liberdade de imprensa e associação e interesse da população por assuntos públicos. De acordo com Adorno (2002), todas essas transformações tornaram a sociedade brasileira mais complexa em suas relações de classe, nas relações interpessoais e na luta por reconhecimento de identidades e de direitos. Podemos, assim, vislumbrar a construção da violência estrutural brasileira. Segundo Minayo (1994), violência estrutural é

aquela que oferece um marco à violência do comportamento e se aplica tanto às estruturas organizadas e institucionalizadas da família como aos sistemas econômicos, culturais e políticos que conduzem à opressão de grupos, classes, nações e indivíduos, aos quais são negadas conquistas da sociedade, tornando-os mais vulneráveis que outros ao sofrimento e à morte. (pg. 8)

Sendo assim, por serem estruturais, perpassam em diversos momentos a vida dos indivíduos e de vários indivíduos, influenciando decisivamente práticas de socialização. De acordo com o papel que incorporaram e, principalmente, que lhes foi possível assumir, os indivíduos podem aceitar o sofrimento que lhes foram impostos ou infligir esse sofrimento a outros.

Felizmente a sociedade foi se tornando cada vez mais participativa, reflexiva sobre os problemas sociais que enfrentava. Mas ainda era preciso saber como lidar com discrepâncias socioeconômicas e situações de não pertencimento que acabam resultando em furtos, roubos, linchamentos, assassinatos e outros atos violentos, compreendendo que esses têm gênese e consequência sociais. Infelizmente a violência cometida pelos menos amparados acaba sendo vista como uma oportunidade para agir com ainda mais segregação ao invés de resolução dos conflitos sociais e políticos, enquanto a violência estrutural cometida contra essas pessoas é minimizada ou sequer reconhecida. 
É imprescindível perceber como violências estruturais e violências individuais estão associadas, pois o que é denominado como ato criminoso de um indivíduo ou grupo de pessoas certamente poderia não ter acontecido caso a justiça social fosse um norte para a ação do Estado e caso o adjetivo "criminoso" não fosse uma forma de manter o status quo. Isso porque as violências originais, aquelas que ocorrem de cima para baixo na hierarquia, são cometidas por estruturas sociais cruéis. Em uma verdadeira armadilha, o ato violento é definido por aqueles que detêm o poder e caracterizado como uma transgressão às regras criadas por esse mesmo poder. Neste jogo perverso, entretanto, não são incluídas as violências como a precária assistência médica, as barreiras educacionais, a fome pela qual passam milhões de famílias e as demais violências silenciosas amplamente perpetradas (Zaluar, 1999).

As desigualdades e exclusões socioeconômicas, portanto, estão diretamente ligadas às ondas de crescimento e instalação da violência. Provavelmente ainda mais determinante seja a injustiça social. E não são medidas como o maior número de policiais ou cidadãos armados, redução da maioridade penal e construção de presídios que resolverão o fenômeno da violência. Ela é socialmente construída e apenas com esforços de cada membro da sociedade e do Estado no sentido de eliminar acúmulo de riquezas nas mãos de alguns, regular os processos de produção, rever a distribuição e utilização da força de trabalho e respeitar os direitos humanos mais básicos é que as mudanças sociais acontecerão e os atos violentos serão encarados de outra forma. Inclusive para que demandas sociais não resultem em relações interpessoais disfuncionais.

Um contexto em que se pode observar bem a violência, seu caráter de fenômeno social e a construção da pessoa que comete um ato violento é, por exemplo, na cobertura midiática da violência. Isso porque a mídia frequentemente assume um papel na segurança 
pública, participa da construção de cadeias ideológicas, reflete a opinião popular e atua como juíza da conduta dos indivíduos.

A teoria mimética proposta por Girard (2011) pode ser vista como uma possível explicação do comportamento e da cultura humanas. Segundo ela, o nosso desejo tem origem também no outro, e quando aspirações vagas encontram um modelo que sugere o que se convém desejar, desejos podem ser socialmente construídos e compartilhados. Tendo em mente a natureza mimética do desejo dos sujeitos, a violência tende a exacerbarse, contagiando a sociedade. O crescimento da violência pode ser analisado como uma imitação que se dá baseada em sobreposições de desejos.

Se o desejo mimético só pode ser entendido socialmente, a rivalidade mimética também é entendida sob essa óptica. Quando o imitador cobiça o objeto de seu modelo, esse intensifica ainda mais seu desejo, levando a uma dupla imitação que aproxima cada vez mais os antagonistas (Girard, 2011). Essa dinâmica altera as relações e a nós mesmos, onde processos de diferenciação frente a essa semelhança fazem-se necessários, podendo alcançar níveis que fogem ao controle. Para resolver a tensão entre antagonistas, faz-se uso do mecanismo de bode expiatório. Este é um fenômeno social no qual um grupo de pessoas elegem, de forma deliberada ou não, e unem-se contra um sujeito na intenção de culpá-lo ou responsabilizá-lo por um fato.

Então, é válido considerar que a mídia, ao noticiar a violência que nos ameaça, acaba por facilitar os comportamentos miméticos e favorecer a expressão da violência. A mídia, ao se apropriar, divulgar, especularizar, sensacionalizar ou banalizar os atos de violência está atribuindo-lhes um sentido que, ao circularem socialmente, induzem práticas referidas à violência. Não se pode negar que violência é linguagem, forma de comunicar algo e, ao reportar os atos de violência a mídia surge como ação amplificadora da linguagem primeira, a da violência. Além disso, a representação da violência pela mídia 
altera a percepção do fenômeno, já que a cobertura nem sempre é representativa do universo de crimes e sim de eventos extraordinários e muitas vezes pontuais.

As problematizações acerca dos discursos contemporâneos da mídia sobre os sujeitos criminosos, estudadas por Brasiliense (2009), são ricas por considerarem a construção social desses que julgamos tão "monstruosos" e reconhecer que o outro, tão desconhecido e perverso, pode estar dentro de cada um de nós. Os discursos naturalizados sobre "pessoas perigosas" inicialmente não admitem que o crime e a maldade estão situados fora da natureza humana, desconsiderando que o caráter dos criminalizados é construído também discursivamente. A maldade tem sido naturalizada devido aos bombardeios cotidianos da mídia sobre violência, e seu componente histórico e humano quase nunca é considerado.

Os processos de interação social impregnam de conteúdo ideológico a consciência, segundo Bakthin (1979), e as questões ideológicas estão situadas entre indivíduos organizados que as constroem como meio de comunicação. Sendo assim, a caracterização de "monstruosidade" dos indivíduos que cometem atos de violência só configura-se desta maneira por estar impregnada de significações ideológicas construídas por um processo discursivo. A construção ideológica acontece por atos de fala, e a atividade mental existe na forma real do signo e em termos discursivos nas palavras; por outro lado o signo realizado no psiquismo sobrevive baseado na ideologia. Logo, toda enunciação se processa por uma síntese ideológica entre o subjetivo e o social.

Esses pressupostos de Bakthin (1979) embasam o entendimento de como a mídia participa das construções ideológicas sobre sujeitos bons e sujeitos maus através de suas falas, infelizmente muitas vezes equivocadas, sobre criminalidade e "monstruosidade". Se somarmos a isso a relação complexa dos sentidos e o fato de que todos os discursos carregam a herança de discursos ditos em outros momentos, percebe-se que esses fluxos de 
cadeias discursivas são ordenados por embates ideológicos, dos quais a mídia, sem dúvida, faz parte e luta para dar voz às suas "verdades". O discurso midiático é organizado pelo meio social em que os sujeitos se encontram, organizando sua narrativa com base no senso comum da sociedade (opiniões sem embasamento científico) e assim facilitando a naturalização de sua ideologia.

As mais diversas ideologias circulantes em nossa sociedade se constroem, muitas vezes, na busca de organizar os fenômenos sociais existentes, de dar sentido a eles. Discursos são elaborados para sustentar as ideologias e geralmente preenchem os vazios deixados pela incompreensão ou falta de explicação da vida cotidiana, inclusive para preencher a angústia sobre nosso papel no mundo. É válido, então, refletir sobre os discursos que produzimos e a ideologia que defendemos, ainda mais nos tempos de liberação de preocupações morais em que aparentemente vivemos, onde o individualismo e a indiferença reinam nas relações sociais (Bauman, 2004). A intolerância tem distorcido os conceitos de direitos, deveres, ética e moral no caos relacional em que nos encontramos atualmente. Sendo assim, é urgente a procura por novas abordagens que respondam às falhas nos direitos humanos, na justiça social e no equilíbrio entre atos individuais e bemestar coletivo.

A tão desejada vida harmônica em sociedade parece precisar cada vez mais de normas éticas para acontecer. Ainda mais visto que cada um de nós tem sua vida influenciada pelos pensamentos e ações dos outros membros da sociedade; o indivíduo não está apartado do meio social maior, essa é uma possibilidade impraticável. Essa percepção do eu-em-relação é fundamental para problematizarmos nosso protagonismo na compreensão das relações sociais atuais. E o pensamento pós-moderno veio para possibilitar novas reflexões sobre os problemas morais e éticos que enfrentamos, onde sujeitos coletivos estão dissolvidos e valores públicos são relativizados (Semeraro, 2006). 
Em um mundo constituído de normas codificáveis, o outro era (ou ainda é) uma presença atordoante e ambivalente, com potencial para ser apoio da identidade do eu e ao mesmo tempo um obstáculo à afirmação do eu. Na ética moderna, o outro era barreira para a realização do eu. Já na ética pós-moderna, readmite-se o outro como próximo, central para o eu moral. Nesse sentido, a ética de Lévinas é pós-moderna. Segundo este filósofo (1987), a humanidade do homem, a subjetividade, é uma responsabilidade pelo outro e o sujeito se constitui na intersubjetividade, não o contrário. Esta caracteriza a Ética da Alteridade proposta por Levinás (Haddock-Lobo, 2006) para repensar as relações humanas, que nos últimos séculos vem reduzindo o outro a nada, e retomar uma aproximação que vá além da representação do outro e o reconheça inclusive em suas diferenças.

Radicalizando o lugar de cada sujeito dentro da sociedade, Bauman (1997) declara que não há nenhum eu anterior ao eu moral. De acordo com ele, a moralidade é intrínseca à nossa subjetividade, ao nosso ser no mundo. A responsabilidade moral não seria algo que carregamos, mas sim parte de nós. Suas propostas conceituais sobre ética e moral são indispensáveis para a problematização acerca da construção das relações sociais e interpessoais e agregam mais uma ideia para a discussão sobre violência realizada neste trabalho: a responsabilidade moral.

Ao se discutir violência, geralmente o foco é encontrar o autor de um possível crime, o motivo para o ato e rapidamente condená-lo; principalmente em crimes contra a vida. Entretanto, e considerando a enorme gama de violências que sofremos diariamente, mais responsabilizações precisam ser problematizadas. Inclusive a de cada um de nós na dinâmica do fenômeno. Ainda mais complexo é incluir um pensar e agir ético e moral ao tema, mas isso não torna essa tarefa indispensável. 
Em uma sociedade caótica, é esperado que seus cidadãos busquem algo em que se apoiar para viverem melhor suas vidas, e Bauman (1997) percebeu as tentativas de universalizar a responsabilidade moral. Mas o sujeito moral age sem roteiro e sem plateia. $\mathrm{Na}$ análise dessa tentativa, o sociólogo observou o que seria preciso para que esse processo se concretizasse e chegou à conclusão que a responsabilidade moral não possui os atributos necessários à universalização: o propósito, a contratualidade e a reciprocidade. Essas características implicam a calculabilidade da ação, e supõem que não há fazer sem racionalização, que só se deve fazer algo quando há uma justificativa para tal e que o viver em sociedade está baseado em contratos.

Segundo Bauman (1997), o propósito divide as ações em úteis e inúteis, fornece a medida e o critério de escolha, estabelece uma preferência; e não é disso que trata a responsabilidade moral. A contratualidade pressupõe que os deveres das partes foram negociados, definidos e acordados antes de se iniciar qualquer ação, não há interesse um pelo outro que vá além da tarefa acordada e não há um interesse no bem-estar mútuo; o dever de cumprir o dever não é do que a responsabilidade moral trata. A reciprocidade implica ponderar a ideia de que vale a pena ser bom para os outros uma vez que é provável que os outros sejam bons para nós. A reciprocidade generalizada pode parecer uma generosidade desinteressada, mas está ligada aos motivos; fazer algo por esperar o mesmo em troca não é do que trata a responsabilidade moral. Por tudo isso, a responsabilidade moral é na verdade livre e solitária.

Além de ensinar e divulgar códigos legais para que os cidadãos estejam cientes de seus direitos e deveres sociais, seria um complemento bastante útil que fossemos sendo ensinados que isso é importante mas não é o bastante. Que "cidadãos de bem" não são aqueles que apenas seguem a lei religiosamente. E que só agir de forma responsável, cuidadosa e moral quando se espera algo em troca não é de fato responsabilizar-se 
moralmente pelo outro. Determinar que nos comportemos de tal forma e não de outra maneira sob o pretexto de que estamos agindo eticamente é universalizar algo que não pode ser padronizado: olhar verdadeiramente o outro.

Segundo este sociólogo:

Só as normas podem ser universais. Pode-se legislar deveres universais ditados como normas, mas responsabilidade moral só existe na interpelação do indivíduo e no ser portada individualmente. Os deveres tendem a fazer os humanos iguais; a responsabilidade é o que nos fazem indivíduos. A humanidade não é captada em denominadores comuns aí ela se submerge e desvanece. A moralidade do sujeito moral não tem, portanto, o caráter de norma. Pode-se dizer que o moral é o que resiste a codificação, formalização, socialização, universalização. O moral é o que permanece quando se faz o trabalho da ética... (Bauman,1997, pg. 66)

Essa é uma proposta ideológica, não só conceitual, chocante a priori mas bastante clara. Ela muda nosso lugar enquanto atores sociais, fazendo de todos nós protagonistas e não mais coadjuvantes nas relações sociais macro e micro e no espetáculo da violência do qual participamos. E ainda coloca em suspenso a funcionalidade das leis que se acredita serem bases sólidas para controle e ordem social. Não só as leis explícitas, mas poderíamos incluir também as normas e convenções sociais que verdadeiramente guiam a vida cotidiana. Deixamos então de acreditar que estamos sendo morais quando apenas seguimos as leis que nos demandam, visto que a responsabilidade moral vai muito além disso. Indignarmos-nos com a violência vai muito além de exigir que o "culpado" seja preso, ou seja, muito além de punitivismo.

Seguindo na proposta de Bauman (1997), poderíamos considerar que os indivíduos são capazes de fazer escolhas morais e, portanto, seria plausível esperar a moralidade de cada um. Apesar disso, podemos observar que essa liberdade de escolher não está sendo confiada aos indivíduos e que o "bem estar social" está passando por outros caminhos e outros atores. As instituições sociais, usando de sanções coercitivas (como censura, força policial, medidas judiciais), tomaram para si a decisão do que é bom ou mau, assim como aponta Foucault (1979) sobre a vigilância e punição constantes em busca do controle 
social. Não necessariamente por uma reflexão pessoal de cada um sobre não poderem fazer escolhas apropriadas, porém não entraremos a fundo no motivo para essa capacidade ter mudado de mãos. Essa mudança de poder não foi uma tomada sutil por parte das instituições nem se deu alheia à colaboração social, possivelmente porque responsabilizarse sozinho por escolhas feitas é um compromisso grande para assumir individualmente. Considerando essas interrelações, é possível perceber como se deu o processo de substituição da moralidade pelos códigos legais. Dessa forma, a responsabilidade moral livre e solitária transformou-se na responsabilidade de seguir as normas ético-legais socialmente acordadas.

A prática moral se dá em meio a ambiguidades e dilemas provavelmente por serem os indivíduos sujeitos ambivalentes. O mar de normas em que vivemos atualmente, onde existem inúmeras leis que podem nos guiar, pode dar uma sensação ainda mais intensa das dúvidas morais que nos acompanham, visto que experenciamos uma incerteza aflitiva (Bauman, 2007). Faz sentido que busquemos alguém ou algo em que confiar, tentando compartilhar a pesada responsabilidade das decisões que tomamos, entretanto as autoridades e instituições que servem de apoio são incertas e contestáveis, inclusive as nossas interações com essas instituições são falíveis (Goffman, 2008). Provavelmente da ambivalência dos sujeitos tenha surgido essa mudança de mãos do poder de decisão, levando à falta de responsabilidade moral - pessoal e intransferível - e a um poder artificial por parte das instituições sociais de decretar o que é bom e o que é ruim para e por todos.

\subsection{Processo de patologização da violência}

Identificar o contexto histórico, cultural, político e econômico em que violências estruturais surgiram e violências interpessoais podem surgir é o começo do caminho para 
pensar em soluções alternativas para os problemas que o fenômeno da violência causa para as duas vítimas, aquele que comete um ato de violência e aquele que sofre um ato de violência em determinada circunstância. Um passo seguinte seria refletir nas soluções encontradas socialmente e executadas por instituições sociais para a crise que a violência sinaliza.

O Estado tem dificuldades em assumir sua responsabilidade na dinâmica da violência, quando não é o próprio que inflige violências contra sua população (Neto \& Moreira, 1999). Quando busca reparar as violências pelas quais é direta ou indiretamente responsável, geralmente atua na ponta final do problema, aplicando a lei para o identificado agressor e prestando assistência pontual à vítima identificada. Parece que a ponta inicial do problema não é incluída no panorama maior do fenômeno, e mesmo compreendendo o quão complicado é reparar séculos de violências sociais, não se pode deixar se tentar. Tanto por uma questão de justiça social quanto por uma estratégia de resolução da violência de forma integrada.

Dada essa dificuldade do Estado e das instituições sociais, pode-se observar que durante toda a história desse país buscou-se alguém em quem depositar a culpa pela violência, alguém que nomeamos atualmente como o "criminoso violento", assim como os anormais que Foucault (2009) sinalizou e que será discutido mais adiante neste trabalho. A escolha desse criminoso violento frequentemente se aproveita da vulnerabilidade de alguns membros da sociedade, e suas características pessoais acabam sendo incluídas na caracterização do eleito da vez. Pessoas com doenças contagiosas e feiticeiros já foram eleitos em séculos passados, assim como os negros vem sendo escolhidos décadas após décadas. E os socialmente vulneráveis eleitos do momento parecem ser as pessoas em sofrimento psíquico. 
Sobre a existência dessa figura nas discussões sobre violência podemos pensar em duas formas de abordagem a esse indivíduo identificado como a fonte dos problemas: se a saída encontrada para resolver a crise da violência é atribuí-la a sujeitos específicos ou se os casos de violência cometidos por pessoas em sofrimento psíquico é que demandam medidas legais diferenciadas. De qualquer forma, uma questão não precisa excluir a outra, é válido refletir sobre as duas igualmente. E proponho discutir sobre esses dois pontos porque de fato indivíduos em sofrimento psíquico estão servindo de bode expiatório dentro do tema violência e porque o Direito também faz parte da discussão sobre violência e se posiciona de forma específica sobre o assunto.

Podemos começar a abordagem a essas questões associando o medo coletivo que se instala quando casos de violência são noticiados e como isso se relaciona com as medidas legais tomadas referentes aos envolvidos. A insegurança social percebida atualmente tem sido relacionada a crimes, e a consequência é o desenvolvimento de uma cultura do medo. Insegurança, medo e violência ficam então associadas, ganham espaço na vida cotidiana das pessoas e essa associação é potencializada pela mídia, agravada ainda mais pela sensação de falta de controle por parte das instituições públicas (Pastana, 2007).

A importância de destacar a cultura do medo é buscar compreender como ela permite que um discurso de poder produza uma imagem de terror social, como o senso comum se apropria desse terror e as consequências sociais e legais dessa cultura. Sobrinho (2014) ressalta que uma das consequências "naturais" dessa cultura do medo é a construção de ideologias que assegurem uma organização social rígida e hierarquizada, mantendo os marginalizados em posições excluídas da participação social. Somando-se a isso há a exigência de ações estatais e institucionais cada vez mais disciplinadoras, e grupos sociais vulneráveis se tornam alvo fácil para violências estruturais e para a culpabilização da violência instalada. 
O pânico social criado em torno da criminalidade resulta em um desejo de punição generalizado, uma forte busca por repressão e uma obsessão por segurança, mesmo que de forma simbólica. Em meio à cultura do medo, atos autoritários são exigidos pela população e vistos como circunstanciais e necessários (Pastana, 2012). Mesmo que emergenciais e arbitrárias, as ações vistas como solução para eliminar esse outro imaginário que causa a desordem social são bem recebidas pela população, pois a sensação de proteção é mais importante do que refletir quem foi o outro escolhido para ser culpado.

Essa cultura do medo é eficiente para garantir a ordem social devido à sua construção em bases sólidas e historicamente bem amarradas. Parte de uma violência estrutural e institucional do Estado, em consonância com um modelo econômico neoliberal onde as regras do mercado de trabalho são cruéis e o caos gerado pela insegurança social inicial chama por um Estado punitivo e rígido a comparecer. Não justo, mas sim um Estado vingativo que vê sua estabilidade ameaçada pelo seu inimigo: aquele - e qualquer um - que coloque a ordem social em cheque. De acordo com Sobrinho (2014), o contexto econômico e político atual encontra complemento institucional no "punho de ferro" do Estado, que individualiza a responsabilidade buscando sujeitos específicos que possam ser caracterizados como perigosos e sacrificados em nome do bem estar social.

Esses sujeitos específicos são eleitos por ameaçarem a ordem social, mais precisamente por serem considerados perigosos - são os loucos e os criminosos. Atualmente a periculosidade é o elemento fundamental para o exercício de medidas jurídico-penais, que visam a extinção do risco e a imobilização do indivíduo perigoso. E não podemos deixar de pontuar que os loucos e indisciplinados são aqueles alvos favoritos do sistema judicial, o que os torna ainda mais vulneráveis. Por seu papel nos sistemas de controle social, a periculosidade foi incluída neste trabalho. 
A periculosidade, como a conhecemos hoje, é um conceito criado a partir da necessidade da Psiquiatria e do Direito de responderam à questão dos crimes inexplicáveis e de seus autores "loucos". A Psiquiatria precisava se afirmar enquanto área da Medicina que atuaria na higiene pública e o Direito buscava respostas para o sujeito criminoso, visto que não bastava o crime e a pena para que a punição fosse efetiva. Segundo Foucault (2004), foi nesse contexto que o criminoso louco foi criado, e a noção de periculosidade está presente nesse novo acordo entre os saberes médicos e os saberes jurídicos. Um acordo bastante útil, pois servia ao problema de ambos, mas questionável quanto ao cuidado que se teve com a criação e fortalecimento de estigmas sociais e com as consequências para a saúde mental dos considerados loucos criminosos.

Fazemos essa consideração porque a loucura nem sempre esteve associada a periculosidade. Pessoas loucas eram compreendidas, desde a Antiguidade, como sendo plenamente responsáveis pelos seus atos. Fosse uma resolução dos deuses ou um conflito dos homens, a loucura não era considerada perigosa, não era uma ameaça social. Ao final da Antiguidade é que apareceu a ideia de que mudanças no comportamento seriam expressões de uma doença orgânica. Inclusive, Hipócrates os via como doentes, necessitados de cuidados médicos, em uma situação episódica e que a loucura poderia acometer qualquer pessoa. E ainda não há nenhuma referência ao perigo. Infelizmente essa nova concepção levou à determinação de um dano permanente no sujeito, ideia que se modificou nos últimos séculos mas que tem sua base ainda ressoando no discurso psiquiátrico e consequentemente nas práticas médico-legais (Barros-Brisset, 2011).

Na Idade Média, essa concepção de déficit orgânico deu lugar à questão do mal, e isso levou ao julgamento moral dos indivíduos com comportamentos desviantes. Para Santo Agostinho, o mal também está presente na origem do homem e é pelo livre arbítrio que se entende a responsabilidade pelas ações, sendo o sacrifício a solução para o desvio. 
Para São Tomás de Aquino, o mal está nas coisas e pode ser encarnada nos indivíduos por meio dos demônios, mas corpos possuídos não podem responsabilizar-se pelos atos maus e insanos que cometeram (Aquino, 2005). Ainda assim, não há a figura do sujeito perigoso. O sujeito poderia fazer o mal, mas ele não era o mal em si. É desse entendimento de que as pessoas portam o mal que procedimentos de identificação, classificação e eliminação do mal surgiram; e os antigos manuais da inquisição que buscavam a reforma dos desviantes por meio da exclusão, da tortura e da eliminação dos corpos são os antepassados dos atuais manuais psicopatológicos.

O que ficou da Idade Média não foi que a loucura era o mal em si, mas que o mal estava associado a uma falta moral; ideia que permanece até hoje. Nos séculos XV e XVI, a loucura foi vista como fonte de sabedoria sobre a natureza humana, uma visão distante das anteriores. No século XVII, a teoria hipocrática da doença orgânica e a teoria metafísica da possessão demoníaca conviveram nas explicações para os insanos e desviantes, porém observa-se a superação do mal psíquico sobre o mal demoníaco. Entretanto ainda não havia uma associação com figuras perigosas. No século XVIII, os insensatos saem das prisões e casas de força e vão para os hospitais gerais, tornando-se assunto médico. O termo alienação mental é reformulado e o conceito passa a sintetizar as hipóteses organicistas e metafísicas, que se fortalece a partir dos trabalhos de Pinel por volta de 1800. E a percepção de alienação mental de Pinel inaugura a ideia de que os alienados sofrem de uma falta moral intrínseca e que dessa doença é possível supor a maldade, a crueldade e a violência (Barros-Brisset, 2011).

Nesse momento os loucos passaram a ser perigosos. Caso o indivíduo pudesse conviver com sua loucura, seu destino seria o hospício. Se seu ato criminoso fosse a consequência da sua falta moral, seu lugar seria a prisão. De qualquer forma, os loucos não poderiam mais escapar de serem vistos como intrinsecamente perigosos. Ademais, teriam 
sua participação social suspensa e não poderiam mais viver com os demais, sendo excluídos através de uma divisão do poder entre as ciências médicas e jurídicas que se proclamaram detentoras da verdade dos sujeitos e aptas a decidir seus destinos, em um claro exercício de arbitrariedade e desrespeito à autonomia pessoal.

Foi a partir da ideia de periculosidade que a necessidade de punição ganhou força, e não a partir do ato criminoso. $\mathrm{O}$ que se viu como necessário a ser combatido foi o indivíduo em si e não as ações e o resultados de suas ações, nem mesmo a proporcionalidade e a retribuição do dano causado (Matsuda, 2009). Ao invés de ater-se à conformidade dos comportamentos com a lei, os sistemas de controle social concentraramse em uma intervenção sobre os sujeitos que resultasse em seu ajustamento e correção moral. O campo penal, então, ganha outros contornos ao deslocar suas ações punitivas do crime para o criminoso.

Com a aliança entre a Psiquiatria e o Direito, no século XIX, o antigo sistema punitivo foi revisto. A alienação mental adentrou o código legal e novos procedimentos foram decididos no que se refere à pessoa que comete um crime e é considerada mentalmente incapaz. O conceito de periculosidade criminal surgiu no final desse século na Escola Positiva do Direito Penal, e a concepção era do ato delituoso sendo considerado um sintoma da periculosidade, uma amostra da "personalidade criminal" do autor do delito (Mecler, 2010). Anteriormente a essa conceituação, Garófalo esboçou, em 1878, a primeira tentativa de sistematização jurídica de periculosidade. Segundo ele, a punição deveria incorporar uma prevenção que atentasse não só para a gravidade do ato mas também para a "temibilidade" do autor, e definiu essa característica como "a perversidade constante e ativa do delinquente e a quantidade de mal previsto que se deve temer por parte do mesmo" (Prado, 2006). 
Há mais de duas décadas já se discute a aplicabilidade do conceito de periculosidade na área do Direito Penal, que vem sendo compreendida, de maneira geral, como uma incapacidade do indivíduo de adequar-se às normas sociais (Bruno, 1984). Críticas devem ser feitas ao termo e seu uso, visto que o Código Penal do Brasil incorporou as concepções da Escola Positiva do Direito. Um dos pontos problemáticos é que a determinação da periculosidade é um julgamento de probabilidade, a probabilidade de que novos crimes venham a acontecer. A questão a ser respondida, então, é sobre o comportamento futuro de um indivíduo, o que é frágil visto que não existe um instrumento ou meio infalível para prever acontecimentos futuros e a inquestionável periculosidade do agente.

Atualmente o conceito de periculosidade, apesar de vago e confuso devido à sua falta de conceituação no Código Penal, é dado como incontestável pelo Direito e profissionais jurídicos, e isso já pode ser problemático desde o início do processo de averiguação do ato criminoso e da caracterização de seu autor. Ao partir do axioma da periculosidade, busca-se uma realidade pré-determinada, fatos, documentos e testemunhos que corroborem uma história escrita de antemão. Ao contrário, se o processo de aproximação ao fenômeno não considerar que existem sujeitos perigosos como uma verdade indiscutível, seria preciso que essa hipótese fosse demonstrada. Assim o valor teórico desse conceito passaria por uma metodologia científica mais acurada e todas as próximas medidas a serem tomadas diante do fato seriam mais justas e alinhadas com a garantia de direitos que nosso Estado supõe.

Uma segunda questão problemática é a solução atualmente encontrada para um caso em que tenha sido determinado o ato ilícito, a inimputabilidade e a periculosidade: a medida de segurança. Podemos pensar na medida de segurança como uma consequência da construção da cultura do medo e do sujeito perigoso, como um caminho legal para 
penalizar pessoas que cometeram um ato criminoso e apresentam algum tipo de sofrimento mental. O primeiro registro da medida de segurança no Brasil data de 1830, no Código Penal do Império. O atual Código Penal, de 1940 e revisado em 1984, traz a medida de segurança associada à inimputabilidade do sujeito (Yarochewsky \& Silva, 2013).

O contexto legal em que a medida de segurança é decidida como a sanção penal adequada é aquele em que ela for aplicada por um juiz de direito, após o processo penal ter passado por seu trâmite regular e se os determinados critérios legais forem preenchidos. Esses critérios são 1) o ato antijurídico praticado; 2) a comprovação de semiinimputabilidade ou inimputabilidade devido a "doença mental" ou desenvolvimento mental incompleto; e 3) a periculosidade do agente do ato (Lebre, 2013). Então, quando há o cometimento de um crime, uma avaliação do suposto agente é realizada para que seja identificada a imputabilidade ou inimputabilidade do acusado, caso haja suspeita para tal. Essa perícia é realizada pelo Instituto Médico Legal, que irá concluir pela existência ou não de uma "doença mental" ou outra condição que justifique a impossibilidade de compreensão do ato e de autodeterminação.

O Código Penal brasileiro consegue definir, diferentemente da periculosidade, quem são os inimputáveis. Em seu Título III, artigo 26 explicita que "é isento de pena o agente que, por doença mental ou desenvolvimento mental incompleto ou retardado, era, ao tempo da ação ou da omissão, inteiramente incapaz de entender o caráter ilícito do fato ou de determinar-se de acordo com esse entendimento" (Brasil, 2010). Além dos penalmente inimputáveis, que são os menores de 18 anos para os quais existe uma legislação especial (Estatuto da Criança e do Adolescente), existe a condição relativa de inimputabilidade. As pessoas consideradas como doentes mentais pelo Código podem estar em uma condição crônica ou transitória, como por exemplo apresentando um transtorno de personalidade ou vivenciando um episódio depressivo. Também são consideradas nesse 
artigo as pessoas que apresentam um desenvolvimento mental incompleto ou desenvolvimento mental retardado, entendidos como aqueles que têm alguma deficiência intelectual, adquirida ou congênita.

É importante adiantar, ainda aqui, uma ressalva sobre o sofrimento psíquico e como ele pode ser transformado em "doença mental" por algumas perícias e avaliações psicológicas. Todas as pessoas sofrem mas nem todas recebem o rótulo de "doentes mentais". Então é possível que a existência de um crime ou ato ilícito pese contra o indivíduo caso ele esteja sofrendo psiquicamente e seu comportamento não esteja dentro das normas legais e sociais. Infelizmente, unir um "louco" a um "criminoso" parece ser de bastante interesse social, político e econômico. Pode ser também o caso da necessidade de atestar a fragilidade decisória do agente para que seu processo seja o mais justo possível. Além do olhar crítico sobre essas sobreposições de vulnerabilidades, é preciso também atentar para a questão da avaliação a ser feita. A seriedade com que é realizada, o cuidado com juízos de valor e o comprometimento com a ética e o cuidado irão determinar o futuro social e jurídico daquele indivíduo.

Definida então a inimputabilidade, a pessoa é absolvida e a ela é designada uma medida de segurança. A medida de segurança, em teoria, não é uma pena, por diferirem em causas, modos de execução e finalidades. A medida de segurança não teria o caráter punitivo da pena, sendo especificamente uma defesa social e prevenção criminal com justificativa na periculosidade. Outra diferença seria que o juiz tem liberdade para decidir sobre a aplicação e execução da medida de segurança, diferentemente da pena comum - o que abre margem para possíveis arbitrariedades e barbaridades por parte do poder judiciário. Ademais, a medida de segurança não possui uma duração determinada, não existe um limite máximo de duração a ser respeitado, apenas um prazo mínimo de um a três anos, podendo ser estendida indefinidamente e a critério dos operadores do Direito 
(Peres \& Filho, 2002). A extinção da medida de segurança está condicionada à cessação da periculosidade, e esta requer mais uma vez um laudo psiquiátrico, como determinado na Lei de Execuções Penais (Brasil, 2008) - ficando agora os acusados submetidos a possíveis arbitrariedades do saber médico.

Entretanto essa condição para a extinção da medida de segurança é uma armadilha jurídica, visto que determinar a cessação de periculosidade é uma tarefa, mesmo que feita adequadamente por um bom profissional, difícil. Determinar com o nível de certeza que o sistema jurídico exige os pensamentos, as emoções e os comportamentos de uma pessoa é uma tarefa delicada. Ademais, ninguém está livre de cometer atos de violência, como veremos ao longo deste trabalho.

Para a doutrina jurídica, a medida de segurança é eticamente neutra e justificada por sua utilidade, servindo para segregação tutelar e readaptação do indivíduo. Não possuiria a característica aflitiva da pena porque foi idealizada com vistas à assistência e tratamento, por meio da medicina e da pedagogia. A privação da liberdade individual ou qualquer outro sacrifício seria apenas um efeito colateral, um meio indispensável à execução da medida (Rossi, 2015). Mesmo entendendo que a restrição de liberdade pode ser indispensável, é preciso considerar como a "prevenção" pretendida com a medida de segurança pode visar apenas o controle social e transformar-se em neutralização profilática dos sujeitos indesejados e indesejáveis. Há um enorme abismo entre o prescrito e o real da medida de segurança, haja visto que muitas vezes há pouca intenção de tratamento, recuperação ou minimização do sofrimento psíquico. Ao contrário, as condições em que a medida de segurança é realizada incapacitam qualquer "correção moral", "recuperação do juízo" ou tratamento psicológico para a tão sonhada reinserção em sociedade.

Segundo o Código Penal, em seu Título VI, a medida de segurança é cumprida em internação em hospital de custódia ou ala de tratamento psiquiátrico, ou tratamento 
ambulatorial (Brasil, 2010). A decisão por uma ou outra forma depende da conveniência devido às circunstâncias pessoais e práticas, apesar de se poder observar que a internação é a regra. Esses Estabelecimentos de Custódia e Tratamento Psiquiátrico foram criados, no Brasil, nos anos 20 e foram centrais para o cumprimento da medida de segurança introduzida pelo Código de 1940. Parece um Código recente, mas diante das discussões sobre Reforma Psiquiátrica e das tentativas de implementar alternativas substitutivas ao modelo tradicional, os artigos que falam de pessoas com sofrimento psíquico precisam ser urgentemente revistos.

No intuito de ilustrar a execução da medida de segurança no país e onde ela ocorre, recorremos resumidamente ao extenso e minucioso censo sobre os Estabelecimentos de Custódia e Tratamento Psiquiátrico, uma pesquisa sobre o perfil da população desses estabelecimentos realizada em 2011 por Diniz, após convênio entre o Departamento Penitenciário Nacional - Depen e o Instituto de Bioética, Direitos Humanos e Gênero da Universidade de Brasília. As informações levantadas foram de três tipos: dados sociodemográficos (sexo, idade, cor, escolaridade e profissão); dados sobre o itinerário jurídico (infração penal, motivo da internação, execução penal, permanências, desinternações e recidivas); e dados sobre saúde mental (diagnósticos psiquiátricos, tipo de responsabilidade penal, exames de cessação de periculosidade, laudos médico-periciais e prazos). Um trabalho de valor inestimável pois pouco se sabia sobre as pessoas que vivam nesses lastimáveis depósitos humanos.

Em 2011 existiam 23 Hospitais de Custódia e 3 Alas de Tratamento Psiquiátrico no Brasil. Nesses estabelecimentos haviam 3989 pessoas, dos quais 2839 estavam em medida de segurança, 117 estavam em medida de segurança por conversão de pena e 1033 estavam em situação de internação temporária. A população total era formada por 92\% (3684) de homens e 7\% (291) de mulheres. 58\% (2322) das pessoas internadas tinham entre 20 e 39 
anos e 38\% (1518) tinham entre 40 e 69 anos. No panorama geral do censo, a população que cumpre medida de segurança é masculina, negra, de baixa escolaridade e com periférica inserção no mundo do trabalho, que em geral cometeu infração penal contra uma pessoa de sua rede familiar ou doméstica (Diniz, 2013).

Não é uma surpresa essa caracterização da população dos Estabelecimentos de Custódia e Tratamento Psiquiátrico se estivermos atentos a todo o contexto social, histórico, econômico e político que vem massacrando certos grupos - inegavelmente negros e pobres - por décadas submetidos a explorações e violências estruturais. Pessoas privadas de amparo (afetivo, institucional e estatal), oportunidades e futuro estão mais vulneráveis a serem engolidas por um sistema de poder que se utiliza de instituições, mecanismos e tecnologias para controlar continua e permanentemente os sujeitos e extermina ou exclui aqueles que não sucumbem à disciplina vigente.

Existiam 741 pessoas nos Estabelecimentos que não deveriam mais estar em restrição de liberdade. Os motivos variam entre a falta de laudo de cessação de periculosidade, a sentença judicial determinando a desinternação, pessoas internadas sem processo judicial ou medida de segurança já extinta. Desses, 55 indivíduos têm a medida de segurança extinta e se mantêm em regime asilar de restrição de direitos. Considerando laudos psiquiátricos ou exames de cessação de periculosidade em atraso, são 1194 pessoas em situação temporária ou em medida de segurança que possivelmente não deveriam estar internadas. Foi registrado que $41 \%$ dos exames de cessação de periculosidade estão em atraso, sendo o tempo médio de permanência a espera de um laudo psiquiátrico de dez meses (o artigo 150, $\S 1$ o do Código de Processo Penal determina 45 dias) e o de espera para o exame de cessação de periculosidade de 32 meses (Diniz, 2013).

Esses dados são alarmantes, e demonstram claramente o descaso com essas pessoas em privação de liberdade. Há uma intenção baseada em valores morais e estratégias 
políticas na manutenção dessas pessoas nos Estabelecimentos de Custódia, e as atrocidades cometidas nos impelem um posicionamento. Esse é um grupo de pessoas que leva uma vida precária, acentuada pela pobreza e pela "loucura", que têm suas dificuldades agravadas pela desatenção de políticas públicas. Além de sua situação pessoal e social, é nítido como essas pessoas estão tendo seus direitos fundamentais violados por um Estado transgressor que sistematicamente abusa do poder, legitimando as violências que se sobrepõem sob o nome de "justiça".

O censo não buscou contestar os critérios judiciais ou psiquiátricos que justificam o sistema, porém mostrou como o poder psiquiátrico-jurídico incorre em erros graves nessa tentativa de "tratar" os inimputáveis. Foi levantada a grave violação dos direitos humanos propiciada por esse sistema: $47 \%$ das informações não se fundamenta por critérios legais e psiquiátricos - pelo menos um em cada quatro indivíduos não deveria estar internado e para um terço deles não sabemos se a internação é justificada (Diniz, 2013). E a prioridade que é dada à internação na execução da medida de segurança demonstra como o modelo manicomial ainda está presente, neste caso possivelmente por serem os Estabelecimentos instituições que compõem o sistema penitenciário, completamente desvinculados do sistema integrado de atenção à saúde mental proposto na Reforma Psiquiátrica.

Impulsionando mudanças de políticas em saúde mental e o movimento da Reforma Psiquiátrica brasileira, em 2001 entrou em vigor a Lei 10216, lei específica sobre a proteção e os direitos das pessoas portadoras de transtornos mentais e que busca redirecionar o modelo assistencial em saúde mental (Brasil, 2001). Certamente não há uma integração entre o sistema de saúde e o sistema penitenciário, visto que a execução e a própria ideia da medida de segurança ferem os direitos das pessoas em sofrimento psíquico, considerando a duração indeterminada da medida, as condições físicas onde ela é cumprida e a ínfima assistência de saúde. 
Podemos ilustrar esse problema através de alguns pontos expressos na Lei 10216/2001. Em seu artigo $4^{\circ}$, a Lei determina que a internação é indicada apenas quando outros recursos não forem suficientes; entretanto, as internações são as maiores indicações jurídicas para o cumprimento da medida, sempre compulsórias e observou-se a violação desse cumprimento na manutenção indevida de indivíduos em Estabelecimento de Custódia. Em seu artigo $2^{\circ}$, alguns dos direitos listados são acesso ao melhor tratamento de saúde, tratamento com respeito e humanidade e proteção contra qualquer abuso e exploração. Infelizmente é sabido que os Estabelecimentos são verdadeiros presídios e depósitos humanos sem a mínima infraestrutura para ser considerado um ambiente terapêutico e servindo apenas como um mecanismo para exercício de poder e instituição disciplinadora do Estado. E que é impossível receber o melhor tratamento quando as pessoas ali não são vistas como humanas e merecedoras de respeito acima de qualquer coisa, nem pelos profissionais pouco capacitados dos Estabelecimentos nem pela sociedade que os isolou (Cordioli, Borenstein \& Ribeiro, 2006).

Apesar do aparente interesse Estatal pelos inimputáveis visto através de dispositivos legais que visam sua atenção, como por exemplo a Portaria Interministerial $n .^{\circ}$ 1 de 2 de janeiro de 2014 e a Portaria n. ${ }^{\circ} 94$ de 14 de janeiro de 2014 (ambas do Ministério da Saúde), o cuidado ainda não chegou efetivamente às pessoas nos hospitais de custódia e alas de tratamento psiquiátrico. Mesmo antes dessas Portarias, o Plano Nacional de Saúde no Sistema Penitenciário havia sido instituído em 2003 e o acesso da população penitenciária a ações e serviços de saúde havia sido legalmente definido pela Lei de Execução Penal n. ${ }^{\circ} 7.210$ de 1984, pela Constituição Federal de 1988, pela Lei n. ${ }^{\circ} 8.080$ de 1990 e pela Lei n. ${ }^{\circ} 8.142$ de 1990. Entretanto, décadas se passam sem que o Mistério da Saúde e o Ministério da Justiça, instâncias máximas responsáveis pelas pessoas em 
privação de liberdade, consigam implementar a desinstitucionalização, os serviços substitutivos e o cuidado dessas pessoas junto à família e comunidade.

A Lei 10216/2001 prevê que pessoas com transtorno mental sejam tratadas no sistema de saúde, porém isso não exime a responsabilidade do sistema penitenciário de oferecer tratamento aos inimputáveis em cumprimento de medida de segurança, já que é de ciência do poder jurídico que aqueles não são presos comuns e precisam de atenção à sua condição psíquica. Ao invés de tratamento de saúde, a medida de segurança revela-se um caminho para a prisão perpétua no Brasil. Como corrobora Barros (2011), o Código Penal e Lei de Execução Penal se tornaram obsoletos com o passar das décadas e das novas demandas para acompanhamento jurídico de pessoas em sofrimento psíquico, além do desenvolvimento técnico e instrumental científico e de saberes da psicologia e psiquiatria. Considerando o tratamento ao portador de transtorno mental referido na Lei 10216/2001 e visando o cumprimento de suas determinações, a aplicação das regras jurídicas é insustentável.

Além de ser uma violação ao direito à saúde mental e expressamente à Lei dos portadores de transtorno mental, a medida de segurança (e todos os conceitos e dispositivos relacionados) fere os direitos mais básicos do ser humano. Porque os protagonistas deste trabalho não são apenas "loucos" e "criminosos", são acima de tudo seres humanos. E é direito de todos, por exemplo, não ser submetido a tortura, pena ou tratamentos cruéis; que perante a lei não haja distinção; e que haja a satisfação de direitos econômicos, sociais e culturais indispensáveis (ONU, 1948). Lastimavelmente, os alvos desses dispositivos legais têm gênero, raça e classe social bem definidos - não há mais como negar que os negros e os economicamente desfavorecidos estão mais vulneráveis a serem criminalizados e patologizados em razão do desamparo social e descaso político. 
O poder jurídico e o poder médico uniram-se para caracterizar aqueles que deveriam ser punidos e de que forma. Entretanto, o extermínio e a exclusão que acontecem com os desviantes sociais acontece ampla e duramente, mas têm sua base bastante frágil já que a periculosidade é uma ficção jurídica fundamentada em diagnóstico e prognóstico falíveis. O Direito cria um caminho legal para julgar, condenar e excluir pessoas socialmente vulneráveis e a Psiquiatria e a Psicologia tentam dar uma certeza aos juristas que não é possível. É urgente tomar ciência das tecnologias de poder empregadas por ambas as áreas e da sua união perversa na estigmatização dos sujeitos escolhidos como bodes expiatórios na patologização da violência e do crime.

Atualmente, quando um crime é associado a uma pessoa considerada "louca", a associação implica um criminoso "incurável”, e isso inviabiliza a percepção de que há uma pessoa por trás do "criminoso" e de que sua loucura decorre de um sofrimento psíquico que merece atenção e pode ser cuidado. A simples categorização das vivências humanas resulta apenas em limitações à aproximação das experiências particulares dos sujeitos, e serve unicamente ao propósito de "coisificar" pessoas visando um seu melhor controle social.

Se a violência é uma construção social, é importante também incluir em nossas análises as pessoas que a constroem, caso contrário corremos o risco de perder um componente do fenômeno. Nem todas as pessoas cometem atos de violência, o que pode nos levar a inferir que as pessoas que as cometem estão inseridas em contextos diferenciados, tanto circunstâncias externas como internas. Já foram ressaltados aqui alguns contextos históricos, políticos, econômicos, culturais e institucionais que parecem estar relacionados à violência. Podemos, com a intenção de complexificar ainda mais as reflexões, buscar compreender como circunstâncias pessoais também podem contribuir 
para a compreensão do fenômeno. Para nos auxiliar nessa tarefa, nos valemos de Donald D. Winnicott. 


\section{Capítulo 2: As contribuições winnicottianas para as elaborações sobre o sujeito antissocial}
O princípio básico do cuidar psicanalítico do ser humano deixa de ser o de ouvir e interpretar o que aconteceu, mas não devia ter acontecido, e passa a ser o seguinte: favorecer a integração do existir humano
no tempo, no corpo e no mundo, integração que não aconteceu ou não aconteceu como devia, acontecência essa que não se explica causalmente, mas humanamente, e não pertence, na sua origem, ao domínio do verbalizável. Zeljko Loparic (1999)

Nosso lugar no mundo, como nos comportamos e nossa posição em relação a ele são resultado de uma confluência entre nossa realidade externa e nossa realidade interna. $\mathrm{O}$ contexto histórico, social, econômico e político de nossas vidas é parte de nossa construção pessoal assim como nossos pensamentos, emoções e idiossincrasias psíquicas. Nesse sentido, a abordagem ao tema da violência é beneficiada pela inclusão de considerações sobre desenvolvimento psíquico. O objetivo com essa inclusão não é personificar o fenômeno da violência, como o senso comum e as instituições responsáveis pelo controle social já fazem, mas sim complexificar as análises do fenômeno.

Quando situações violentas ocorrem, alguém geralmente é apontado como o responsável. Porém suposições sem fundamento, superficiais e preconceituosas não colaboram para a compreensão sobre a pessoa que comete violência, não contribuem para elucidações sobre o fato ou o fenômeno. Responsável sim é buscar formas críticas e humanas de analisar o assunto e assumir que qualquer um a qualquer tempo pode agir de forma violenta. Excelentes proposições teóricas foram feitas na busca por esse aprofundamento, e a psicanálise winnicottiana foi uma delas.

Para Winnicott, dentro do seu contexto britânico, os fatos eram a realidade e as teorias uma forma de alcançar os fatos. Não acatava dogmas ou se conformava facilmente, como é possível perceber pelo seu fazer experimental na clínica e a criatividade com que 
articulava os conceitos na teoria. Foi essa personalidade livre que o permitiu reinventar grandes psicanalistas e construir sua própria explicação para os fenômenos psíquicos. Ele acreditava que nada era dado ou absoluto (Khan, 1958), e que todo homem precisaria encontrar e definir sua própria verdade. Perceber esse psicanalista auxilia na compreensão de suas propostas teóricas e a lê-las criticamente.

\subsection{O desenvolvimento emocional}

Para melhor compreender a teoria sobre a tendência antissocial winnicottiana e como ela abre outros caminhos para as análises sobre violência, é essencial percorrer o caminho do desenvolvimento emocional proposto por ele. Suas propostas partem do entendimento de que o potencial para o desenvolvimento psíquico está presente desde a primeiríssima infância, no relacionamento entre a mãe e o bebê, e sua teoria pode ser considerada como uma proposta de "vir a ser" de cada ser humano.

O ponto crucial para este psicanalista e de onde parte o desenvolvimento emocional dos sujeitos é a vulnerabilidade inicial do bebê e sua relação com a mãe (Winnicott, 1986), e não o complexo de Édipo como propôs Freud. Partindo desse relacionamento de dependência, fenômenos mais abrangentes do potencial de desenvolvimento humano para alcançar a autenticidade pessoal iam sendo tratados, denominada por ele como "sentir-se real” (Loparic, 2001). Esse é um paradigma novo na Psicanálise, que abre caminho para que a psique seja encarada como uma construção constante e não encerrada em uma determinação primária, e propõe que o potencial humano está a espera de evolução de acordo com as vivências possíveis de cada um em seu contexto de vida mais amplo.

Rejeitando o naturalismo e o determinismo, Winnicott (1970) recusa a objetificação do ser humano - assim como nós o fazemos neste trabalho. Ao invés de conceber o ser humano como consequência causal em sua relação com a natureza, ele é entendido como 
um ser acontecendo no tempo até sua morte. Sendo assim, não está submetido à previsibilidade e calculabilidade que o homem moderno buscou ao criar o método científico. Até hoje esses pressupostos estão presentes na ciência contemporânea, porém não há razão de mensurar e é quase impossível assegurar a previsibilidade de um sujeito em constante "acontecência".

O ser humano acontece mas não o faz de forma aleatória, e sim dentro de um ambiente, que pode ser facilitador ou não. Essa outra grande mudança no paradigma engloba tanto o relacionamento com a mãe, sendo a mãe-ambiente o ambiente inaugural, quanto o ambiente familiar e o ambiente social mais amplo. O potencial para o amadurecimento depende em grande parte de como o ambiente agirá em relação ao bebê. Para Winnicott (1958), o indivíduo é um ser que não se pode conhecer enquanto isolado e que só pode personalizar-se através do outro. Novamente suas propostas mostram-se apropriadas à intenção deste trabalho de sair da superficialidade da violência enquanto fenômeno social e mostrar como as relações, inclusive de poder, são essenciais na compreensão da violência como resposta a contextos sociais e pessoais específicos.

As teorias sobre a personalidade geralmente tem como fundamento comum a ideia de continuidade, onde entende-se que as vivências de uma pessoa não se perdem, mesmo que por razões complexas essas experiências não estejam ao alcance da consciência. Na teoria winnicottiana do desenvolvimento emocional esse pressuposto também é válido: as experiências que o bebê vive darão início à sua vida psíquica e o acompanharão em seu amadurecimento. No bebê ainda não há diferenciação e não-diferenciação e sim um conjunto fisiológico e um potencial psicológico para o desenvolvimento da personalidade. Aqui é preciso ressaltar o pressuposto winnicottiano de que o bebê não existe sem sua mãe, visto que inicialmente ela é um objeto subjetivo do bebê que o auxiliará em sua integração rumo à independência (Loparic, 2001). 
Ao dizer que "o bebê é algo que não existe", o psicanalista chama atenção para o fato de que onde há um bebê há também uma maternagem, e que sem ela não existiria criança alguma. Ele argumenta que a relação mãe-bebê é crucial para o início do seu desenvolvimento. Durante a infância, acontecem coisas boas e más que estão fora do controle da criança, justamente nesse momento em que a capacidade para viver fatores externos como onipotência está se formando (isso não é negativo e essa projeção é importante para o desenvolvimento sadio do bebê). A questão é que o apoio dado pela maternagem permite que ele viva e se desenvolva (Winnicott, 1960).

O potencial psicossomático para a integração terá a chance de se manifestar caso encontre condições ambientais favoráveis, e a maternagem suficientemente boa entra nessa ideia. O termo mãe suficientemente boa refere-se à função de maternagem no início da vida de uma criança. Essa função pode ser exercida pela mãe biológica, por uma mãe adotiva ou por um cuidador substituto. Mais especificamente, o termo identifica um ambiente suficientemente bom. Com suficientemente bom entende-se um ambiente que está atento às necessidades físicas e psíquicas do bebê. $\mathrm{O}$ bebê nasce sem um ego que possa exercer suas funções, então a mãe-ambiente tem o papel de ego auxiliar. Decorre que a condição básica para o cuidado do bebê é a continuidade do ser, que é possível quando os cuidados são contínuos e acontecem sem grandes intercorrências e perturbações (Hisada, 2011).

Os bebês se favorecem quando estão em dependência absoluta com uma mãe suficientemente boa porque podem brincar de criar o mundo sem se preocupar com a sobrevivência física e com interrupções bruscas no cuidado. $O$ conseguir ser suficientemente bom que permita a constituição do bebê precisa acontecer no estado de preocupação materna primária (Winnicott, 1956), que é uma condição gradualmente desenvolvida que aumenta a sensibilidade da mãe para as necessidades do bebê. A mãe 
também já foi um bebê, brincou de ser pai e mãe e foi formando suas próprias ideias a respeito disso, afetada substancialmente pelos hábitos de sua comunidade. Então ela precisa recorrer inclusive às suas próprias lembranças e sensações da primeiríssima infância no cuidado de seu filho.

Nossas primeiras relações são o protótipo para nossas futuras relações, aprendemos a nos relacionar com o modo como se relacionaram conosco no início do nosso desenvolvimento emocional - reiterando, com o auxílio do trabalho de Winnicott, que ninguém "nasce mau" ou "nasce psicopata", nós constantemente aprendemos como colocar nossas emoções nas relações. Uma adaptação não suficientemente boa perturba a criança, produz reações às invasões percebidas por ela e interrompe a sua continuidade de ser. E o continuar a ser é fundamental para o desenvolvimento saudável que está por traz dos bons relacionamentos humanos.

Em resposta ao que de fato então é comunicado quando uma mãe se adapta às necessidades de seu bebê, o psicanalista introduz o segurar o bebê, o holding. O segurar refere-se ao contexto em que as comunicações mais importantes do bebê acontecem quando suas experiências se iniciam. O uso da palavra segurar traz tanto a dimensão da mãe segurando o bebê quanto do bebê sendo segurado pela mãe, caminhando nas fases de sua afirmação como pessoa. Seu desenvolvimento é favorecido pela sensação de confiança consequente do fato de estar sendo segurado. $O$ bebê nasce não integrado psicossomaticamente, por isso o holding é essencial para dar sentido às suas sensações corpóreas e psíquicas. Permite que sua vida seja minimamente contínua, que vivencie situações descontínuas sem se desintegrar e o movimento confortável entre essas situações torna-se um padrão e forma base para as experiências do bebê (Winnicott, 1968).

Esses eventos interpessoais acontecem na dependência absoluta, um estado no qual o bebê se beneficia da maternagem mas não consegue saber dela de fato; o primeiro 
estágio do seu processo de maturação e onde seu potencial para se integrar está à disposição dos estímulos ambientais. O estágio seguinte é a dependência relativa, onde o bebê começa a ter conhecimento da maternagem e da dependência e a se adaptar às graduais falhas do ambiente, auxiliado pela compreensão intelectual. Rumo à independência é o passo seguinte, ficando claro que a independência nunca é absoluta (Winnicott, 1963). Aqui o sujeito consegue seguir em seu amadurecimento sem os cuidados reais e através de lembranças de cuidados, da projeção de necessidades pessoais, da introjeção de detalhes da maternagem e da confiança no ambiente.

Com o prosseguimento da maturação e a aquisição de um interior e um exterior, a confiabilidade do meio ambiente pelo bebê passa a ser uma crença. Não se pode subestimar o papel do ambiente no desenvolvimento emocional de um indivíduo, tanto por sua participação na constituição quanto na reparação necessária ao longo do amadurecimento. $\mathrm{O}$ ambiente é capaz de gerar na criança em formação a sensação de segurança e de ser amado. Sobre isso Winnicott (1986) diz:

São as inúmeras falhas, seguidas pelo tipo de cuidado que as corrigem, que acabam por constituir a comunicação do amor, assentada sobre o fato de haver ali um ser humano que se preocupa. (pg. 87)

A primeira organização do ego surge a partir de experiências de falhas que não levam à aniquilação, e das quais o bebê repetidamente se recupera. A partir dessas experiências, a confiança na recuperação leva ao ego e a uma capacidade do ego de suportar a frustração. Quando os cuidados iniciais essenciais não são suficientes, ele é invadido por estímulos. Se a estimulação estiver em um nível suportável, ele ficará alerta e será preparado para situações futuras. Se for uma estimulação além do que ele pode suportar, o bebê ficará submetido a esses estímulos e um trauma pode ser estabelecido. O trauma é uma estimulação que invade o psiquismo e ultrapassa a capacidade do ego de se defender, podendo levar a uma sensação de aniquilamento, de morte. De certo, suportar as 
invasões depende do cuidado e da capacidade de acreditar construída na criança. Onde há uma reação de raiva ou ódio apropriados, o fracasso ambiental não foi maior que a capacidade do indivíduo de lidar com a sua reação. (Winnicott, 1965).

A quebra no continuar a ser, causada por sucessivas reações às invasões, pode levar a tal ameaça de aniquilamento que o indivíduo se vê obrigado a ocultar seu verdadeiro self. Dessa forma o falso self se constitui convenientemente sintônico com o meio ambiente. É preciso mutualidade para que o verdadeiro self possa ser sentido como real. De acordo com Winnicott (1960), o verdadeiro self é a fonte do gesto espontâneo, o único que pode ser criativo e se sentir real. É essencialmente não reativo e provém da vitalidade corporal e suas funções. $\mathrm{O}$ falso self se desenvolve para proteger o verdadeiro self, para ocultar a realidade interna da criança e buscar condições ideais para a livre expressão do verdadeiro self. Todos possuem um self educado ou socializado e também um self privado que só aparece na intimidade, e isso é considerado comum e normal pelo psicanalista.

O falso self pode acabar tomando conta da vida psíquica do sujeito, substituindo a espontaneidade por uma adaptação submissa ao ambiente. Podemos facilmente perceber como alguém que comete violência pode ser, na verdade, alguém forçado a substituir o existir por reagir devido às exigências externas e internas. Um sujeito reativo ao seu ambiente, que não vê outra forma de sobreviver em sociedade se não por ações extremas de proteção da sua individualidade, do seu self.

O self é a pessoa que se é, a totalidade de ser do indivíduo; diferentemente do ego. Em seu processo de maturação, o self alcança importante relação entre a criança e o somatório das identificações que compõem sua realidade psíquica viva. A relação da criança com sua própria realidade psíquica interna se modifica de acordo com as expectativas ambientais, conferindo dinamicidade à sua constituição. Apenas o self tem 
sentido de ação e de vida e pode identificar-se com objetos de amor maduros sem perder sua identidade individual (Khan, 1958).

Existe uma diferença entre essas falhas relativas do cotidiano e as falhas fundamentais de adaptação. As falhas não intrusivas da mãe e que são suportáveis pelo bebê podem gerar transicionalidade, pois ali há um espaço a ser preenchido. Quando a criança já consegue diferenciar o eu do não-eu, é capaz de criar uma representação do outro, do ambiente materno facilitador, e a transicionalidade diz respeito a isso. Ela não é dentro nem fora, eu nem não-eu; contém cada um mas é de uma qualidade diferente. $\mathrm{O}$ termo transicional é utilizado para designar a área intermediária de experiência, de experimentação.

De acordo com Winnicott (1951), essa terceira área da vida recebe contribuição tanto da realidade interna quanto externa, e não é contestada, não precisa dar conta das respostas do mundo externo ou das angústias do mundo interno, o que favorece a experimentação e o exercício da criatividade. É um espaço de repouso da infinita tarefa de equilibrar as duas realidades. Sua característica também remete à ilusão, à ilusão de criação de seu mundo por algum tempo; que na vida adulta é própria da religião e da arte. Inclusive, é essa experiência ilusória que, se compartilhada, permite a formação de agrupamentos humanos. O que acontece nesse espaço é chamado de fenômenos transicionais, e essas experimentações ocorrem através do objeto transicional. A importância do objeto transicional é que a criança pode levar com ela a confiança no ambiente, o que proporciona a ilusão de criar a própria tranquilidade, podendo ser um amuleto, foto, peça de roupa, entre outros.

Winnicott (1967) propõe que a experiência cultural está no espaço potencial que existe entre o sujeito e seu ambiente, assim como o brincar proporcionado pelos fenômenos transicionais. O espaço potencial acontece entre extensões do eu e do não-eu e viável 
apenas pelo sentimento de confiança, relacionada à fidedignidade da figura materna na infância ou dos elementos ambientais. Se a criança não tiver oportunidade de viver criativamente, não existirá área para o brincar e consequentemente não haverá experiência cultural, comprometendo os vínculos com a herança e contribuição culturais.

As proposições do psicanalista são brilhantes na correlação entre o cuidado primário e as experiências iniciais e as consequências futuras do desenvolvimento emocional. Seus questionamentos e organizações conceituais trazem outra perspectiva para a compreensão da violência e das pessoas que cometem um ato de violência. Especulações superficiais não dão conta da complexidade por trás dessa passagem ao ato. A criação de uma figura simplesmente cruel ou "psicopata" não colabora nas discussões sobre violência, visto que acaba deixando de lado elaborações fundamentais sobre o desenvolvimento psíquico, muitas vezes, oculto no comportamento observável.

Quando se discute sobre pessoas que cometeram violência, até mesmo no âmbito jurídico, frequentemente é levantada a questão da "falta de coração" ou da "falta de remorso", que podemos nos referir nessa discussão psicanalítica como preocupação. Ela é, de fato, importante na vida social, entretanto mais complexa do que se imagina. Winnicott dedicou elaborações também a isso (1963), e compreende a capacidade de se preocupar como a retenção de uma culpa que aguarda a oportunidade de fazer a reparação. Se não há, no início do desenvolvimento, uma figura materna confiável para receber a reparação, a culpa se torna intolerável e não é possível sentir preocupação. Fracassos na reparação levam à perda da capacidade de preocupação, dando lugar a ansiedade e culpa primitivas.

Diferentemente do que se costuma ouvir sobre a culpa ser resultado de um ensinamento religioso ou moral, Winnicott, principalmente, compreende a capacidade de preocupação (expressão conceitualmente mais adequada do que "culpa") como um aspecto do desenvolvimento emocional humano. As influências culturais são reconhecidas por ele 
como importantes no processo da capacidade de preocupação, porém assinala que elas não podem ser plenamente estudadas sem considerá-las inseridas em padrões pessoais.

A utilização do termo superego por Freud (1923) para referir-se ao que é aceito pelo ego para controlar o id foi importante para a formulação teórica da culpa como um conflito pessoal entre ódio e amor. A engenharia que o ego precisa empreender para satisfazer o id, e ao mesmo tempo freá-lo para que se possa obter o máximo de vantagens do ambiente, foi reconhecida por Winnicott como um caminho para compreender que a culpa moral relaciona-se com a realidade interna, enquanto a culpa legal relaciona-se com o ato ilícito. Considerando as propostas freudianas, a capacidade de se preocupar implica que o ego e o superego estão em conciliação (Winnicott, 1958), que a ansiedade sentida devido ao conflito entre ódio e amor amadureceu em direção à preocupação.

Outra contribuição preciosa na teorização psicanalítica sobre a culpa é a de Melanie Klein, que direcionou o olhar dos psicanalistas para o estágio da posição depressiva dentro do desenvolvimento emocional. Seu trabalho sobre a gênese da capacidade para o sentimento de culpa (1935), inclusive, foi resultado do uso da teoria de Freud. Sem fazer extensas explanações sobre as propostas teóricas de Klein, na posição depressiva, a criança precisa da chance de fazer reparações, que é oportunizada quando há estabilidade e continuidade nos relacionamentos externos. Então, gradativamente a criança descobre que a mãe sobrevive aos seus ataques instintivos e aceita sua restituição, o que permite que a criança aceite responsabilidades por suas fantasias do impulso instintivo. Winnicott vê que aí, no desenvolvimento inicial, a piedade toma o lugar da crueldade e a preocupação ocupa o lugar da despreocupação.

Essa fase do desenvolvimento, a partir das contribuições kleinianas, é vital para o desenvolvimento da capacidade de sentir culpa e é composta por incalculáveis repetições deste ciclo: há uma experiência instintiva que gera a aceitação de responsabilidade (culpa), 
demandando uma resolução que resulta em um gesto reparador verdadeiro. A falha em algum desses pontos pode ter consequências indesejadas, levando à ruína da capacidade para o sentimento de culpa e sendo substituída pela inibição do desejo ou o splitting de objetos bons e maus como defesa.

Tendo esses dois mestres como influência, Winnicott (1958) consolida suas elaborações sobre a psicanálise do sentimento de culpa. Acredita que o sentimento de culpa refere-se à coexistência de amor e ódio, e que esse extremo da capacidade para preocuparse deve ser raro. Sendo assim, aqueles que não fortaleceram a capacidade de preocupação não estiveram em uma situação emocional e física que permitisse o desenvolvimento dessa capacidade. As condições ambientais necessárias a esse desenvolvimento são complexas mas não impossíveis, e nada mais são do que é natural e consistente no cuidado da criança.

A capacidade de se preocupar só é possível quando há a integração do ego, o que exige que os estágios iniciais tenham acontecido de forma satisfatória, sem traumas. A partir daí, em sucessivas situações favoráveis, a capacidade de preocupação vai sendo construída, intimamente relacionada à mãe-ambiente e à oportunidade de reparação. Winnicott (1958) reconhece que em algumas pessoas houve um impedimento do desenvolvimento emocional e consequente dificuldade no desenvolvimento da capacidade de preocupação, e alerta que a falta dessa capacidade torna necessário um código normativo externo, mas que essa substituição resulta em uma socialização instável.

Essas elaborações winnicottianas permitem uma forma diferenciada de refletir sobre as relações de via dupla entre o sujeito e o ambiente, que o tempo todo vão criando possibilidades de amadurecimento, consolidando integrações ou dificultando o desenvolvimento. Apesar de potenciais muitas vezes serem impedidos no desenvolvimento de cada pessoa, em seus contextos específicos, suas histórias determinam mas não 
encerram possibilidades. Afinal, falhas são espaços vazios e espaços vazios permitem novos crescimentos.

\subsection{A tendência antissocial}

Do estudo do desenvolvimento emocional, surgem pontos essenciais para a compreensão e discussão da violência neste trabalho: os que se referem à agressividade e à tendência antissocial. Seria difícil discutir esse fenômeno tão complexo sem as elaborações e referências às particularidades psíquicas que Winnicott faz com tanto cuidado e competência.

A fim de fazer uma melhor leitura dos questionamentos propostos neste trabalho, e como já ficou claro na retomada dos pressupostos winnicottianos, é fundamental manter em mente que uma pessoa transforma e é transformada tanto por fenômenos internos quanto por fenômenos externos. Como afirma Tschirner (2001), tanto as significações feitas na realidade interna conforme suas características pessoais, constitucionais e pulsionais, quanto as relações com o mundo externo onde e por meio do qual transformações de significados acontecem, se inter-relacionam para nos colocar de determinada forma diante de certos eventos.

Com isso estabelecido, podemos passar a proposições mais complexas e explicativas do componente mais pessoal do fenômeno da violência. Antes de Winnicott, a etiologia da delinquência e criminalidade era atribuída à ansiedade ou à culpa, ou seja, era pertencente aos conflitos do mundo interior do indivíduo. Entretanto o psicanalista considera decisivo o fator ambiental, e a necessidade de um ambiente seguro e estável durante a infância (Winnicott, Shepherd \& Davis, 1987). Suas vivências durante a Segunda Guerra Mundial foram cruciais para consolidar essas percepções e contribuíram para a busca de explicações para a aparente irracionalidade do comportamento antissocial. 
Durante a Segunda Guerra, após pesquisas feitas em um hospital de Londres, Winnicott, Bowlby e Miller observaram como a separação prolongada de uma criança pequena de sua mãe era um fator externo importante na causa da delinquência persistente. A evacuação de crianças entre dois e cinco anos levava a problemas psicológicos sérios, enquanto a saída de crianças mais velhas parecia ser suficientemente bem sucedida (Winnicott, 1939). Além da delinquência crônica, foram observados distúrbios de comportamento moderados e facilidade para doenças físicas indefinidas. Para o psicanalista, deixar o lar poderia ser vivido como mais do que uma simples experiência real de tristeza, marcando fortemente o desenvolvimento da personalidade e a capacidade para as relações sociais.

A importância do trabalho e das reflexões de Winnicott durante a Guerra foi, entre outras, a de ter sensibilidade para perceber o que a evacuação em tempos de guerra pode nos mostrar sobre os cuidados com crianças, não só os físicos mas os cuidados com o ser humano total que é uma criança. Sabendo-se que a criança tem uma capacidade limitada de manter viva a ideia de alguém amado quando não tem contato com esta pessoa (Winnicott, 1945), e que a ameaça de perda desses sentimentos é real para ela durante uma evacuação, a atenção de alguns pais adotivos em prover um lar ao invés apenas de uma casa foi fundamental para sua continuidade de ser. Dar um pouco do mundo que a criança pode compreender e no qual pode acreditar, quando o amor falha, é uma das grandes lições tiradas da observação de crianças evacuadas. E esse cuidado e adaptação às necessidades do outro em momentos de fragilidade é algo que pode - e deve - ser feito com adultos em situação de vulnerabilidade, tanto social quanto afetiva.

Por mais tristezas que a evacuação tenha causado e por mais longa que tenha sido, a volta para casa não é um processo apenas feliz. Pais e filhos precisam se reencontrar com seus lugares na família, desiludir do lar que fantasiaram que seria no reencontro e contar 
com o tempo para o ajuste das relações. Pode-se observar uma criança mais livre e solta quando de volta ao seu lar e à sua família (Winnicott, 1945), isso porque ela não precisa mais utilizar o autocontrole rígido de quando estava fora. Seu regresso pode ser o começo de uma nova vivência de liberdade, caso ela possa sentir a realidade daquilo que é real, com o auxílio da confiança. Então agirá livremente, e seu comportamento poderá incluir birra, provocar preocupações nos pais e até pequenos furtos. Esses são sinais de avanço no desenvolvimento pois demonstram, além da devolução do controle aos pais, testes no sentimento de segurança. Vê-se aqui uma amostra de como o estudo sobre crianças evacuadas foi importante para o início das elaborações sobre a tendência antissocial.

O colapso observado devido à evacuação ficou claro nas angústias que se traduziam sintomaticamente em enurese e incontinência, explosões maníacas, fases depressivas, comportamento excêntrico e deterioração da personalidade. Ademais, as dificuldades eram expressas em roubos, depredações, evasão escolar e fuga dos alojamentos (Winnicott, 1947). A percepção desse fracasso na evacuação levou as instâncias governamentais a buscarem a solução em tratamento psicológico individual e alojamentos diferenciados enquanto as crianças estavam em tratamento. E foi possível observar que não eram lares adotivos ruins que provocavam dificuldades nas crianças, mas que grande parte dos fracassos ocorria com crianças que vinham de lares instáveis ou que não tiveram um exemplo de bom ambiente em seus lares, ou ainda que viveram desintegrações na família. Percebeu-se que a elas não bastavam bons lares substitutos, mas sim experiências de lar primário satisfatório.

Sobre isso Winnicott explica (1947), mostrando os caminhos para a compreensão do fator ambiental na tendência antissocial:

Por experiência de lar primário entende-se a experiência de um ambiente adaptado às necessidades especiais da criança, sem o que não podem ser estabelecidos os alicerces da saúde mental. Em alguém especificamente orientado para as suas necessidades, a criança não pode encontrar uma relação operacional com a realidade externa. Sem alguém que lhe 
proporcione satisfações instintivas razoáveis, a criança não pode descobrir seu corpo nem desenvolver uma personalidade integrada. Sem uma pessoa a quem possa amar e odiar, a criança não pode descobrir seu sentimento de culpa nem o seu desejo de restaurar e recuperar. Sem um ambiente humano e físico limitado que ela possa conhecer, a criança não pode descobrir até que ponto suas ideias agressivas não conseguem realmente destruir e, por conseguinte, não pode discernir fantasia de fato. (pg.63)

Winnicott, em nossa compreensão, foi preciso em seu conhecimento sobre o psiquismo e em sua colocação, indicando como o ambiente é fator decisivo no desenvolvimento emocional do ser humano, não pode ser omitido e será solicitado a comparecer quando dificuldades forem experenciadas.

Programas foram criados para implementar os alojamentos, equipes com pessoas da comunidade, assistentes sociais e psiquiatras foram criadas e o resultado com crianças potencialmente antissociais foi notório (Winnicott, 1948). As dificuldades das crianças foram entendidas como uma questão de saúde individual e social e não como uma vingança pública inconsciente, e provavelmente essa postura foi essencial para o sucesso do programa. A punição não teria efeito dadas as necessidades das crianças, e o amparo e amor vivenciado nas relações foram mais eficazes para evitar os delitos. Não é preciso tratar adultos como crianças para se ter um olhar sensível e um cuidado apropriado que a permita assumir responsabilidades e encarar dificuldades com confiança. Quando uma pessoa é capaz de obter algo bom e positivo do ambiente, quando encontra pessoas verdadeiramente confiáveis, é capaz de confiar e acreditar nelas e em si mesma.

Winnicott (1948), por ter trabalhado em alojamentos, considerou que o programa de assistência às crianças em tempos de guerra também poderia ser utilizado no tratamento de antissociais em tempos de paz. Ele compreendia o comportamento antissocial como um estabilizador da sociedade, um retorno do reprimido, um sinal de espontaneidade ou impulsividade. E que, analogamente às crianças com problemas em seus lares e famílias, a necessidade era por estabilidade ambiental, cuidados individuais e continuidade desses cuidados. Concordamos que essa é uma via responsável, ética e cuidadosa. Mesmo 
sabendo que a contenção física pode ser a única medida real para a salvação do sujeito, acreditamos que seja preciso repensar a forma como o encarceramento tem sido feito nos dias de hoje.

Considerando a sociedade como um local que permite a transicionalidade, como um espaço potencial, ela pode ser mais que uma fonte de adoecimento. A sublimação não é suficiente para compreender os fenômenos culturais, é preciso um local onde a vida criativa possa ser livre e sua interação com a cultura permita formas saudáveis de estar em sociedade. É nas trocas sociais, melhor ainda se elas forem favoráveis ao amadurecimento, que se pode ressignificar relações insuficientes ou danosas. Contando com um ambiente suficientemente bom, nessa área de experiência intermediária que pode ser a cultura, o sujeito pode transitar mais relaxadamente entre o subjetivamente percebido e a realidade externa compartilhada.

O trabalho durante a Segunda Guerra, além do seu conhecimento em Freud e Klein, permitiu a Winnicott uma inovadora proposta para o papel da agressividade no psiquismo. Já no final dos anos 30, ele foi muito claro ao tirar a agressividade da sombra colocando-a como elemento do amor e do ódio que constituem o mundo psíquico e as relações com o mundo externo (Winnicott, 1939). O bem e o mal presentes nas relações humanas estão presentes na constituição do ser humano, apesar da agressividade ser negada e atribuída a agentes externos. Isso porque, quando se manifesta, mobiliza o sujeito e o ambiente de maneiras muitas vezes desconhecidas para eles. Uma das importâncias de reconhecer e aceitar a própria agressividade é que ela pode estar organizada em fantasias inconscientes, e caso a agressividade não esteja bem integrada no self, pode causar desespero, angústia, ansiedade de aniquilamento, que podem levar indiretamente a uma atitude antissocial.

A fim de compreender mais profundamente a agressividade, é imprescindível ter em mente do que se fala quando nos referimos à agressividade. Quando dizemos que ela é 
inerente à natureza humana, não o fazemos no sentido biológico, e sim no sentido de fazer parte do estar vivo. Apesar de inerente, ela se desenvolverá e fará parte do indivíduo apenas se for permitido experenciá-la. E aqui reforçamos que é a forma como o ambiente lida com essa potencialidade que determinará o modo como a agressividade será vivida. Caso o ambiente seja suficientemente cuidadoso, reconheça e aceite essa manifestação humana, a agressividade inicial será integrada à personalidade e utilizada nos relacionamentos interpessoais, no brincar, no trabalhar e no processo de territorialidade. Entretanto, caso não seja integrada, será escondida, por meio do autocontrole, ou cindida do self; e essa não-integração pode resultar em comportamento antissocial, destruição compulsiva ou violência.

Sendo assim Winnicott (1964), ao tratar das raízes da agressão, considera que ela possui dois significados: ser uma das muitas fontes de energia ou constituir, direta ou indiretamente, uma reação à frustração. Na tentativa de observar o início da agressividade em um indivíduo, encontraremos o movimento do bebê. Ele movimenta-se, e ao fazer isso, dá de encontro com algo. Essas primeiras pancadas infantis levam à descoberta do mundo que não é o eu da criança e ao começo de uma relação com objetos externos. Acompanhando essa tendência para movimentar-se e obter prazer muscular no movimento, há a organização das ideias destrutivas conscientes ou inconsciente e as reações a tais ideias. O que poderá ser um comportamento entendido como agressivo, no início, não passa de um impulso que leva a um movimento e aos primeiros passos de uma exploração, facilitando a descoberta do mundo externo.

Essa motilidade inicial está relacionada à agressividade primeira considerando esta como espontaneidade, e não no sentido de agressão que a criança compreende mais a frente em seu desenvolvimento. Até porque ela, nesse estágio de dependência absoluta onde se verifica o movimento em sua grande manifestação, não é um indivíduo completo e 
integrado que possa colocar intencionalidade em sua ação agressiva; e para Winnicott agressividade só faz sentido quando movida por um propósito. A busca do bebê por aliviar sua tensão instintual o faz descobrir o mundo externo, o não-eu, e essa movimentação e a resistência imprimida pelo ambiente se tornam fonte de energia para a continuação de seu amadurecimento físico, psíquico e sua integração.

O segundo lugar onde podemos encontrar explicações para as raízes da agressão é na frustração ambiental, que tem grande importância no final da dependência absoluta e início da dependência relativa. Como o bebê é completamente dependente da mãe para continuar a ser, repetidas falhas ambientais interrompem essa continuidade e um estado vago de alerta se instala. Uma raiva surge, porém o bebê ainda não está maduro o suficiente para perceber esse ambiente suficientemente bom que o cuida, por isso o sentimento não é organizado e sentido como tal, mas não deixa de ser registrado. A raiva desaparece devido à experiência não organizada do trauma, e não como uma ação do superego freudiano. No caso de um ambiente invasivo e que falha em falhar, ou seja, que insiste em se adaptar quando o bebê já não necessita mais disso, uma alternativa encontrada é a reclusão em um mundo interno. Ao se voltar para fora, o indivíduo pode estar sensível demais às demandas externas, se sentir perseguido e se tornar agressivo (Dias, 2000).

Poder tolerar tudo o que encontramos em nossa realidade interior é uma das grandes dificuldades das pessoas, e um dos importantes objetivos humanos é estabelecer relações harmoniosas entre as realidades pessoais internas e as realidades exteriores. Quando existe esperança na capacidade interna, a vida instintiva está ativa e o indivíduo pode aproveitar do uso desses impulsos, incluindo os agressivos, convertendo em bem na vida real o que era dano na fantasia. Isso constitui a base do brincar e do trabalho. A extensão em que podemos ajudar a criança no sentido da sublimação é limitada pelo estado 
do seu mundo interior. Se a destruição for excessiva e incontrolável, a reparação que a criança conseguirá fazer é pouca. Tudo que ela poderá fazer é negar a propriedade de fantasias más ou dramatizá-las. Quando as forças destrutivas ameaçam dominar as forças de amor, o sujeito precisa fazer algo para salvar-se, e uma das alternativas é colocar para fora seu íntimo, dramatizar exteriormente o mundo interior, representar ele próprio o papel destrutivo e provocar seu controle por uma autoridade externa.

Fato é que a agressividade está sempre ligada à constituição da realidade externa, ao estabelecimento da distinção entre o eu e o não-eu. Por trás da origem da força da agressão e que é subjacente à destrutividade está a destruição mágica. Ela é comum no início do desenvolvimento e é acompanhada da criação mágica que a criança também faz do mundo. A destruição mágica ocorre na passagem dos objetos que deixam de ser parte de mim para serem "não-mim", ou seja, o fenômeno deixa de ser subjetivo e passa a ser objetivamente percebido (Winnicott, 1964). Assim sendo, a agressão não pode mais ser encarada apenas como negativa e a agressividade é compreendida de forma mais complexa e coerente com a história pessoal de casa sujeito. O indivíduo precisa de tempo para adquirir formas de lidar com o choque de perceber uma realidade que existe fora de seu controle mágico e, amadurecendo, poder destruir e odiar em vez de aniquilar magicamente o mundo.

Relacionado ao destruir está o construir, e é preciso falar disso e dos processos subjacentes nesta discussão sobre agressividade e tendência antissocial. Na vida social, o envolvimento que pode acontecer devido às relações interpessoais é uma característica importante. Ao nos referirmos a envolvimento, baseados na teoria winicottiana, estamos falando do fenômeno positivo da culpa. Esta vincula-se à ambivalência e requer uma integração que permita a coexistência da imagem do objeto bom e da sua destruição, como 
já discutido aqui. O envolvimento, então, diz do preocupar-se ou importar-se, de sentir e aceitar responsabilidade.

Essa capacidade está por trás de todo o trabalho e brincar construtivos, e emerge no começo do desenvolvimento da vida emocional da criança. $O$ brincar permite que o indivíduo experimente tudo que existe em sua íntima realidade psíquica, que é a base do sentimento de identidade. Haverá tanto agressividade quanto amor, e a criança aprenderá que seu brincar não é só destrutivo, mas também construtivo (Winnicott, 1964). Quando ela consegue combinar a experiência amor-ódio em relação a um único objeto, a ambivalência é alcançada. Isso é importante no processo porque seu enriquecimento e aprimoramento levam à emergência do envolvimento.

Winnicott (1963) ressalta que a oportunidade de dar e de fazer uma reparação, que é possível através da presença confiável da mãe-ambiente, torna o bebê hábil a ser mais audacioso na vivência de suas pulsões do id, ou seja, liberta sua vida instintual. Assim, a culpa não é sentida mas permanece adormecida e só aparece, como tristeza ou depressão, se a oportunidade de reparação não acontecer. Então, a não sobrevivência da mãe-objeto (aquela que atende às necessidades) ou o fracasso da mãe-ambiente em propiciar uma oportunidade confiável para a reparação leva à perda da capacidade de envolvimento e à sua substituição por angústias e defesas cruas, como a clivagem ou desintegração. A ausência de um sentimento de culpa acarreta na inibição do impulso. Ao invés dele, instala-se o medo, e a criança se inibe em relação a todo o sentimento que se constrói em torno dele. É só a partir da culpa que se sente por atacar o objeto de amor que há o impulso para ser construtivo.

Esclarecido então que a agressão tem mais relação com espontaneidade do que com destruição, que agressividade traduz bons níveis de integração, que não é sinônimo de violência e que ambas podem estar presentes no psiquismo de todos os seres humanos, 
podemos apreender melhor a proposta winnicottiana sobre a tendência antissocial. Ele, inclusive, tinha bastante clareza quanto a como comportamentos antissociais expressos em delinquência despertam o sentimento de vingança pública e que isso apenas causa paixões inúteis e sentimentalismo quanto ao real problema: "o crime como doença psicológica" (Winnicott, 1946, pg.129). Podemos compreender a "doença psicológica" a que ele se referia como o sofrimento psíquico que entendemos atualmente. De qualquer forma, podemos ver em sua consideração uma ética de cuidado fascinante que direciona o olhar sobre o jovem antissocial para sua deprivação vivida na família e o pedido de ajuda que o comportamento antissocial instalado significa.

Em sua compreensão, ainda nos tempos de guerra, do que seria uma criança passando por um desenvolvimento normal, observa que é comum que ela tente se impor no lar caso possua confiança em seus pais. Então faz o que jovens que chegaram aos tribunais também tentaram: testam seu poder de desintegrar, cansar, manobrar, apropriar-se e destruir. Caso o lar consiga suportar a tentativa de desorganização, a criança se acalma e se envolve com outras atividades. É importante notar que essa tentativa de mostrar poder por meio da desorganização geralmente acontece quando há dúvidas sobre a capacidade do lar e dos pais de se manterem estáveis. É preciso saber que há uma referência de estabilidade e controle antes de viver com liberdade sua espontaneidade e poder ser irresponsável (Winnicott, 1946).

Percebe-se que os comportamentos antissociais na infância dizem respeito aos conflitos do início do desenvolvimento emocional. Essa necessidade de amor e força ocorre por temor dos próprios pensamentos e imaginação, em um contexto psíquico no qual a relação com a realidade externa ainda não está firme, a personalidade está em vias de completar sua integração, ainda não se sabe bem tolerar e enfrentar os próprios instintos e o amor primitivo é destrutivo. Caso a ideia de referência parental tolerante e firme ainda 
não faça parte da personalidade, a criança busca o prazer livremente até perceber que não há referência e angustiar-se com isso. O que se segue é que, se ainda houver esperança, ela buscará fora do lar a estabilidade externa que não encontrou. Winnicott (2005) complementa:

A menos que se veja em apuros, o delinquente só poderá tornar-se cada vez mais inibido no amor e, por conseguinte, cada vez mais deprimido e despersonalizado, tornando-se por fim totalmente incapaz de sentir a realidade das coisas, exceto a realidade da violência. (pg.131)

A perspectiva winnicottiana dos comportamentos antissociais muda completamente a forma de encarar episódios de violência, cometidos não só por jovens mas também por adultos. Ter a sensibilidade de ver que ninguém "nasce mal" ou "não tem solução" transforma o olhar para essa pessoa e procurar ver o não dito, o não atuado. Por trás de comportamentos socialmente indesejáveis não há apenas uma figura perversa, mas uma história pessoal e familiar com características muito próprias e que demandaram do sujeito respostas específicas para a sua sobrevivência psíquica.

Uma década depois das elaborações iniciais sobre o comportamento antissocial, Winnicott (1956) faz um registro mais definitivo sobre o assunto. A questão não é apenas a delinquência, mas uma tendência antissocial. Ela pode, sim, ser expressa por meio da delinquência, do furto, da mentira, da agressividade e até da incontinência e enurese. Entretanto ressalta que é o valor do incômodo causado que caracteriza o comportamento antissocial, indicando o que é importante que se observe e deixando abertas outras possibilidades de expressão. A tendência antissocial pode surgir, especialmente, em um momento do desenvolvimento no qual há uma fusão das raízes agressivas (motilidade) com as raízes libidinais como pano de fundo para a deprivação vivida. Porém a tendência antissocial não é exclusiva da infância e pode ser verificada em qualquer idade. 
Apesar de ser erroneamente utilizada, a tendência antissocial não é um diagnóstico, e pode ser encontrada em um indivíduo "normal", neurótico ou psicótico. Ela pode ser melhor vista como uma defesa organizada, que possui ganhos secundários e de difícil compreensão por quem não entende o desenvolvimento emocional devido às reações sociais que provoca. Porém no contexto do amadurecimento e da integração, sua causa não é ininteligível. Vamos analisar a tendência antissocial a partir de três questões fundamentais em sua manifestação: a deprivação que a causa, a participação do ambiente e a esperança que ela reflete (Winnicott, 1956).

A deprivação acontece, geralmente, na família ou no lar responsável pelos cuidados iniciais do indivíduo. Isso porque na base da tendência antissocial está uma experiência inicial boa que se perdeu, ou seja, há uma deprivação de algo significativo para a criança no seu processo de amadurecimento. Há uma relação direta entre a tendência e um desapossamento de algo bom que foi positivo na experiência. Essa retirada, essa perda, persistiu por um período além do que a criança pode manter a lembrança da experiência viva. Isso é importante porque não se trata apenas de uma carência ou de qualquer falha, mas de uma ausência insuportável psiquicamente. Além disso, é fundamental que o bebê esteja em um momento do desenvolvimento em que possa perceber que a causa do caos interno foi uma falha ou omissão ambiental. Essa percepção correta de que a desintegração ocorreu por um fator externo é que leva à busca de resolução em novas condições ambientais.

O ambiente tem grande participação porque uma nova organização sua possibilita a dissolução dos comportamentos antissociais. É muito próprio da tendência antissocial chamar o ambiente a participar e lhe atribuir importância, e através de pulsões inconsciente o indivíduo encarrega alguém de cuidar dele. Há uma busca de firmeza, estabilidade e amor por trás de comportamentos antissociais, que demonstrariam ao indivíduo que o 
ambiente sustenta a impulsividade expressa e não falhará ou se omitirá novamente. A destrutividade, o furto e o roubo podem ser entendidos como essa procura por estabilidade ambiental e como a busca de objeto bom perdido. Em qualquer das direções que a tendência antissocial pode assumir, busca-se confiança e liberdade que permitam o movimentar, agir e se excitar espontaneamente. É um pedido de ajuda para recuperar a confiança no ambiente e assim poder ser livre para ser e continuar se desenvolvendo sem preocupações com possíveis falhas insustentáveis.

A esperança é o que move e permite essas buscas, e no momento de esperança o indivíduo observa se o novo ambiente parece confiável, tenta um movimento impulsivo na busca do objeto perdido e mobiliza o ambiente alertando-o para o perigo de sua impulsividade e para que ele se organize de forma a tolerar o incômodo. Esse processo pode repetir-se inúmeras vezes para testar a capacidade do ambiente de sobreviver à agressão, para impedir ou repará-la, para reconhecer o que há de positivo na tendência antissocial e para responder à busca com o objeto procurado e preservá-lo. Caso essa expressão de esperança aconteça satisfatoriamente, a criança pode ser capaz de encontrar e amar uma pessoa, ao invés de buscar objetos substitutos. Entretanto, o que frequentemente se observa são desperdícios desse momento de esperança devido a uma administração ruim da situação ou intolerância. $\mathrm{O}$ que o indivíduo precisa para superar sua tendência antissocial é que alguém vá ao seu encontro e corresponda à sua esperança.

Toda essa caracterização leva ao reconhecimento de que a técnica clássica da psicanálise não é o tratamento ideal para a tendência antissocial (Winnicott, 1956). Ela permitiu sua compreensão profunda e a perspicácia de Winnicott o fez chegar onde a psicanálise tradicional não foi capaz de explicar, mas não é ela a provisão ambiental que o indivíduo necessita. Porque é de necessidades que a tendência antissocial diz respeito, necessidade de um ambiente estável onde os impulsos do id podem ser experimentados 
novamente, onde eles possam ser testados. Isso permite que eles façam sentido em sua ligação com o ego. O apoio ao ego falhou na situação de deprivação, e satisfazer as necessidades do ego é essencial até que o indivíduo possa introjetar o ambiente que suporta e mantê-lo vivo apesar das deficiências do ambiente real. Uma psicoterapia individual pode ajudar, mas não seria suficiente sem um ambiente suficientemente estável e apoiador, entendendo esse ambiente como a família, a comunidade, a escola e os demais meios onde o sujeito está.

Podemos chegar ao consenso de que a sensação de desamparo pode ocorrer ao longo de toda a vida. Segundo Winnicott (1971), essa sensação pode ser elaborada no espaço potencial, aquele entre a realidade externa e a construção interna de um sentido para aquela realidade. Recorrendo à transicionalidade e à experiência de ilusão, em uma situação de privação o bebê pode lidar com uma realidade difícil por meio de sua criatividade. E, se o desenvolvimento emocional aconteceu de forma satisfatória, o adulto também teria capacidade criativa para sobreviver a frustrações e dificuldades externamente criadas.

Obviamente nossos desejos nunca são satisfeitos e às vezes nossas necessidades não contam com o auxílio de um ambiente facilitador para serem satisfeitas. Apoiados na tendência ao amadurecimento, podemos olhar para essas falhas como oportunidades de crescimento e aperfeiçoamento psíquicos. Porém, certamente um indivíduo que recebeu apoio em sua infância para seu uso da ilusão terá mais recursos internos para fazer escolhas saudáveis e cuidar de si mesmo.

Como já foi visto, a experiência cultural pode ficar comprometida quando o indivíduo não foi capaz de aprender a brincar enquanto criança, uma oportunidade que não é aproveitada devido à privação (Winnicott, 1967). Essa retomada é importante porque essa repercussão na cultura é resultado da perda de algo que foi aceito como fidedigno ou 
de um objeto. Isso leva à perda de um símbolo significativo, algo que compunha o psiquismo e que implica o ambiente nessa perda. Todos nós podemos ser considerados ambiente e, na medida em que não sabemos a dimensão que nossas ações repercutirão na vida do outro, precisamos assumir nossa responsabilidade moral e olhar verdadeiramente para o outro, buscando compreendê-lo para nos relacionarmos com mais cuidado. Por outro lado, por sermos todos ambiente, nossas atitudes podem ser a resposta à esperança de alguém e ter sensibilidade para pedidos de ajuda "disfarçados" de comportamentos antissociais pode fazer a diferença entre a manutenção de um sofrimento psíquico e reintegração do self com sua confiança interna.

Mesmo a tendência antissocial não sendo um quadro diagnóstico como a psicose ou como um transtorno de humor ou de personalidade, tem havido tentativas de classificá-la nosologicamente. Como acontece com qualquer fenômeno desconhecido, "estranho" ou que causa medo, pessoas que apresentam comportamento antissocial têm despertado a curiosidade da Psicologia e da Psiquiatria, que buscam organizá-la em sinais e sintomas e com um prognóstico claro visando o controle social desses considerados "desajustados". Se isso não for possível, pelo menos encontrar uma psicopatologia que se assemelhe e que possa ser inteligível.

Não se pode ignorar que em casos de violência, o diagnóstico do sujeito que a comete é rapidamente feito, seja por profissionais da Psicologia ou da Psiquiatria, por pessoas que não são da área ou por profissionais da mídia. Assim sendo, ao discutir o fenômeno social da violência e a subjetividade de quem pode cometê-la, é coerente e necessário abrir um espaço para refletir sobre as avaliações que tentam classificar os sujeitos, as consequências disso e alternativas mais éticas e não superficiais de organizar uma análise que tenha o propósito de ajudar verdadeiramente o sujeito em suas dificuldades ao invés de apenas rotulá-lo e segregá-lo. 


\section{Capítulo 3: A tentativa de patologização da tendência antissocial e outras possibilidades diagnósticas}

Na realidade, rotular os indivíduos que se sobressaem,
ou que são incapacitados por problemas da vida,
de "doentes mentais" apenas impediu e retardou
o reconhecimento da natureza política e moral
dos fenomenos para os quais se dirigem os psiquiatras.

Thomas Szasz (1974)

Provavelmente faça parte de todas as áreas do conhecimento que visam explicar algo o trabalho de classificar o objeto de análise buscando identificá-lo, organizá-lo de acordo com as suas características, compará-lo a outros objetos e tentar prever seu comportamento futuro. A princípio não há nada de errado com isso e muito da evolução do conhecimento produzido pelo homem se deu dessa forma. Parece uma atividade legítima e relativamente simples se bons procedimentos forem utilizados por profissionais dedicados. Entretanto não é difícil imaginar o quanto essa tarefa se complica se o objeto em análise for o ser humano. A tentativa de dar sentido ao caos humano não é simples, porém isso não impediu que pensadores das mais diversas áreas do conhecimento arriscassem-se a ordenar a complexidade humana.

Especialmente nas disciplinas psis - Psicanálise, Psicologia e Psiquiatria - o diagnóstico é uma tarefa comum na prática clínica e frequentemente solicitada por outras especialidades que utilizam da interface em suas atividades, como o Direito, a Economia, a Administração, entre outras. Quando se intenta compreender e explicar o comportamento humano, as disciplinas psis estão em um caminho privilegiado possivelmente por disporem de teorias e técnicas específicas para alcançarem o psiquismo e por, muitas vezes, olharem com profundidade e compromisso ético para as idiossincrasias que surgem nesse campo.

Antes da apropriação médica, onde o diagnóstico se popularizou, o uso do vocábulo era mais amplo. Foi usado por dramaturgos; por Aristóteles para significar a distinção e 
apreciação de algo de valor, e por Platão em referência à discriminação que os juízes deveriam fazer em seus julgamentos e valor de indenizações e multas no caso de morte de escravos. No campo médico, referia-se ao reconhecimento de uma doença e decisão sobre tratamento. Essa forma de compreender o diagnóstico mantém-se até hoje e inclusive de forma ampliada, quando se fala, por exemplo, de diagnóstico econômico e social. Independente do campo é denominado sempre como um trabalho de conhecimento e reconhecimento de sinais, que sejam úteis para determinar a identidade de algo (Saurí, 2001).

A fim de entender porque essa é uma tarefa amplamente utilizada e tão realizada nas áreas psis, podemos fazer uma breve observação da etimologia da palavra. A semântica do vocábulo é integrada por termos como diagignosko: separar e decidir; diagnome: deliberação e decisão; diagnomon: perspicaz, vigilante e atento; diagnorizo: fazer, conhecer e divulgar; e diagnostikos. Assim, diagnosis nomeou originalmente o fato e os atos de reconhecer e discenir. E deu forma a uma área relativa a um modo de conhecer que consistia em separar e discriminar. Diagnosticar era, a princípio, conhecer racionalmente algo de modo lúcido e perspicaz, mergulhando no que é possível conhecer e verificá-lo tomando uma decisão (Saurí, 2001). Sendo assim, a tarefa diagnóstica é bastante útil na compreensão de inúmeros fenômenos, e também pode ser para a violência e seus atores.

\subsection{O diagnóstico em contextos de violência}

É da curiosidade e necessidade de explicações que nasce o pensamento humano orientado para uma organização de passos que facilitem o alcance das respostas. Porém a busca cega por tornar todas as áreas de conhecimento uma ciência não garante as certezas que se procuram e não tornam os achados inquestionáveis. As disciplinas humanas parecem acolher de forma menos controversa o olhar qualitativo para os fenômenos do 
mundo, que compreendem que a investigação dos fenômenos humanos possui as especificidades de criar e atribuir significado às coisas e pessoas nas interações sociais. Obviamente o tratamento estatístico tem seu lugar nas pesquisas qualitativas, desde que usado com sobriedade. A complexidade dos fenômenos humanos pode ser alcançada por caminhos que deem espaço para o fenômeno acontecer e permitam uma análise apropriada dos dados observados e colhidos.

De certa forma é isso que acontece na Psicologia Clínica, que utiliza do diagnóstico como norteador da prática clínica, por onde é possível conhecer demandas, traçar intervenções e repensar estratégias e fundamentá-lo no tratamento e cuidado. A Psicanálise também pode ser vista como um campo investigativo, e não só uma escola de pensamento e uma prática psicoterápica, visto que nomeia um método de investigação que busca o significado inconsciente das palavras, ações, sonhos, fantasias e delírios, utilizando basicamente a associação livre de palavras e também as produções humanas que não se manifestam por essa via (Pontalis \& Laplanche, 2001). E a Psiquiatria, até mesmo por ser herdeira de um pensamento médico, usa do diagnóstico como um meio de eleger uma patologia e identificar sinais e sintomas que a justifiquem, chegando a um enquadramento muitas vezes limitado.

Problema aristotélico, o diagnóstico tem sido uma tarefa psicológica e psiquiátrica recorrente na prática clínica mas que, justamente por isso, parece escapar de um olhar mais crítico sobre seu objetivo e sua seriedade. Há muito já se sabe (Dalgalarrondo, 2008) que além de ser imprescindível considerar os aspectos mais pessoais, mais singulares de cada indivíduo, o diagnóstico orientado para questões psicopatológicas é importante para compreender de forma acurada o sujeito e seu sofrimento. Ademais, ter em mente que o diagnóstico não passa de uma ideia, um construto, é importante para não confundi-lo com a 
realidade absoluta daquele indivíduo. O diagnóstico não é um objeto real, mas sim uma construção ideológica.

A fim de que este trabalho seja adequadamente lido e compreendido, nossa postura é crítica com relação a este procedimento que utilizamos nos variados trabalhos que realizamos. Entendemos que o diagnóstico, compreendido filosoficamente como uma atividade de identificação, discernimento e aprofundamento na coisa em si, é legítimo e bastante útil na prática clínica, visto inclusive como um cuidado com a situação vulnerável e sofrida em que nossos clientes se encontram. Entretanto isso não exclui nossa reflexão sobre como o diagnóstico tem sido feito na Psicologia e na Psiquiatria, pois nos preocupamos com a falta de conhecimento teórico, técnico, cultural, social, histórico e político que muitas vezes (não) embasam o trabalho diagnóstico.

Mesmo o funcionamento psíquico não sendo um objeto de análise facilmente sujeito às leis matemáticas, nós enquanto pensadores do humano seguimos na tentativa de compreendê-lo melhor. Além da psicoterapia, o psicodiagnóstico tem se mostrado um caminho possível e útil. Por ser um tipo de avaliação psicológica com objetivos clínicos e que procura identificar no funcionamento psicológico tanto forças quanto fraquezas (Cunha, 2000), o psicodiagnóstico tem potencial para ser utilizado de forma ampla e não restritiva à patologia. $\mathrm{O}$ mal uso do psicodiagnóstico é bastante sério, pois levanta dúvidas sobre o compromisso ético do profissional com o cuidado e respeito ao outro e pode indicar motivos políticos no controle social que se intenta por meio do sofrimento psíquico denominando-o de doença mental.

Entretanto, caso o psicodiagnóstico e demais avaliações psicológicas sejam realizadas de forma séria e responsável, o resultado pode ser valioso. Por meio do processo de avaliação é possível, por exemplo, acessar conteúdos que podem ser devolvidos ao cliente no processo psicoterápico e orientar a articulação de cuidados com outros 
profissionais. A associação das disciplinas psis com "doença mental" revela uma associação subjacente entre a clínica e a patologia (Avoglia, 2012). Grande parte dessas associações pode ser resultado de uma prática estigmatizante e superficial por parte dos profissionais, que possivelmente não compreendem adequadamente o sentido das avaliações psicológicas. Uma pessoa não é só suas falhas e fraquezas, é preciso reconhecer isso e buscar as forças e potencialidades no funcionamento psíquico e social, incorporando essa nova postura nas práticas clínicas diárias.

Uma avaliação psicológica frequentemente possui o foco, ainda que inicial, no sujeito em si. No que ele pensa, sente e como se comporta, em como se sai em um teste psicológico ou nas respostas que dá a uma entrevista. Em conformidade com Avoglia (2012), entendemos que essa análise deslocada de um contexto prejudica a apreensão do seu sofrimento e sua personalidade. Afinal, é na relação com sua comunidade, família, trabalho, representantes e vivências culturais que o sujeito se autodetermina, expressa suas particularidades, se transforma e transforma o meio. A articulação com o contexto social no processo diagnóstico, então, não é uma simples opção do profissional. É essencial para não desconectar o sujeito dos vínculos que o fazem ser quem é.

Em se tratando de situações de violência essa busca pelas condições sociais que permeiam a existência do sujeito é especialmente fundamental. Provavelmente o comportamento agressivo que perturba a sociedade está articulado ao espaço onde o sujeito vive, atua e representa papéis; onde sofre pressões, responde a elas e tenta existir enquanto equilibra dificuldades e capacidades em busca de sua sobrevivência física e psíquica.

Quando um episódio de violência é noticiado, geralmente o primeiro questionamento recai sobre a sanidade ou a perversidade de quem o cometeu. Uma psicopatologia é logo atribuída, o uso de drogas é levantado e avaliações de todos os tipos são feitas - infelizmente um diagnóstico social dificilmente é realizado. Profissionais de 
saúde são chamados a se posicionar e, dependendo das especificidades do crime, o rótulo psicopata começa a circular na mídia. Em situações como essa, as avaliações psicológica e psiquiátrica exercem um poder bastante expressivo, baseadas no triplo papel que evocam: reproduzir o crime, na medida em que características que a princípio não são infrações articulam-se como indícios do crime; anunciar o culpado, por serem inferidos os antecedentes do suspeito que o assemelhem ao crime mesmo antes deste ter acontecido; e atestar a criminalidade intrínseca à personalidade do acusado, transformando-o em condenado (Foucault, 2002).

O diagnóstico, enquanto atividade de categorização do mundo, deixou de ser uma atividade clínica pautada no exercício filosófico e passou a servir ao campo jurídico através da avaliação psicológica e psiquiátrica. A princípio não há ao que se opor na interdisciplinaridade entre Direito e Psicologia ou Psiquiatria, entretanto a união dos dois criou um poder difícil de ser contraposto: o poder de interditar os sujeitos.

No serviço prestado pelos psicólogos e psiquiatras aos juízes e outros operadores jurídicos, a fim de legitimar ainda mais o poder, conhecimentos, procedimentos e instrumentos cientificamente reconhecidos são buscados para subsidiar a avaliação do sujeito requerida. Nesse sentido, os manuais diagnósticos e os testes psicológicos são invariavelmente utilizados. Listas de sinais e sintomas se multiplicam e psiquiatras procuram validar instrumentos que sirvam para achar determinados sintomas no sujeito. Um dos mais utilizados, mas já nem tão respeitado, manuais diagnósticos é o DSM (Manual Diagnóstico e Estatístico de Transtornos Mentais, APA, 2013). Nele é possível achar os mais específicos sintomas para as mais inusitadas psicopatologias.

No contexto da violência e da Psicologia Forense, alguns dos transtornos mentais listados no DSM são mais citados, como é o caso do Transtorno de Conduta e o Transtorno de Personalidade Antissocial (TPAS). É importante conhecê-los pois eles fazem referência 
direta a comportamentos violentos e são utilizados na construção da personalidade criminosa que interessa tanto às disciplinas psis quanto às disciplinas jurídicas. Existem muitos termos utilizados para se referir ao que a sociedade considera a personificação do mau: psicopata, maníaco, psicótico, monstro entre as diversas alcunhas criadas. Poderíamos dizer que no DSM o correlato dessa tentativa de nomeação para pessoas que causam danos às outras seria o Transtorno de Personalidade Antissocial.

Antes de especificar sobre isso, o Manual define um transtorno de personalidade como um padrão persistente de vivência íntima ou comportamento que se desvia acentuadamente das expectativas da cultura do indivíduo, generalizado e inflexível, com início na adolescência ou começo da fase adulta, estável ao longo do tempo e que provoca sofrimento ou prejuízo. Além disso, o padrão se manifesta em duas ou mais das seguintes áreas: cognição, afetividade, funcionamento interpessoal e controle de impulsos (APA, 2013).

O que é caracterizado como um transtorno ganha um peso negativo. Transforma-se o amadurecimento de um self que precisa constantemente negociar desejos e necessidades com o meio externo e que enfrenta dificuldades nesse equilíbrio em um referencial de doença. Claro que o sofrimento que encobre as potencialidades para amadurecimento e adaptação precisa ser acompanhado e minimizado, mas patologizar o sofrimento nessa vertente psiquiátrica que o DSM faz não colabora para o seu entendimento e cuidado e apenas cria "doenças mentais" para formas de ser no mundo e para dificuldades que todos enfrentam na vida cotidiana.

Especificamente sobre o TPAS, o DSM (APA, 2013) define que é um padrão invasivo de desrespeito e violação dos direitos dos outros, que ocorre desde os 15 anos, como indicado por pelo menos três dos seguintes critérios: (1) fracasso em conformar-se às normas sociais com relação a comportamentos legais, indicado pela execução repetida 
de atos que constituem motivo de detenção; (2) propensão para enganar, indicada por mentir repetidamente, usar nomes falsos ou ludibriar os outros para obter vantagens pessoais ou prazer; (3) impulsividade ou fracasso em fazer planos para o futuro; (4) irritabilidade e agressividade, indicadas por repetidas lutas corporais ou agressões físicas; (5) desrespeito irresponsável pela segurança própria ou alheia; (6) irresponsabilidade consistente, indicada por um repetido fracasso em manter um comportamento laboral consistente ou honrar obrigações financeiras; (7) ausência de remorso, indicada por indiferença ou racionalização por ter ferido, maltratado ou roubado outra pessoa. Além disso,o indivíduo precisa ter no mínimo 18 anos de idade, evidências de Transtorno da Conduta com início antes dos 15 anos de idade e a ocorrência do comportamento antissocial não se dar exclusivamente durante o curso de Esquizofrenia ou Episódio Maníaco.

Uma questão que se nota na caracterização do Transtorno de Personalidade Antissocial é que é fácil alguém preencher seus critérios e não ser o que se entende por "psicopata". Por serem comportamentos, são superficiais com relação à subjetividade e podem acontecer em vários momentos da vida. É possível ver a “impulsividade em fazer planos" nos jovens, o "desrespeito irresponsável pela segurança própria ou alheia” quando dirigimos sem cinto de segurança, a "propensão para enganar" quando mentimos que estamos doente para nossos chefes, e o "fracasso em conformar-se às normas sociais" em todos os pensadores que procuram mudar o status quo a fim de transformar a realidade social.

Segundo Davoglio \& Argimon (2010), a reação psicopata sempre contém comportamentos antissociais, mas nem todo comportamento antissocial diz respeito à psicopatia ou ao Transtorno de Personalidade Antissocial. Mais do que o nome dado à coisa, é preciso se concentrar na coisa em si. A falta de interesse em acessar a 
psicodinâmica dos ditos psicopatas limita as alternativas terapêuticas e o destino social dessas pessoas, e a única resolução parece ser o encarceramento. O TPAS tem funcionado como um carimbo de intratável que assegura que essas pessoas fiquem excluídas da sociedade indefinidamente, um respaldo psiquiátrico para prender pessoas sob a alegação de inimputabilidade. A explicação "ela é má por isso faz essas coisas" sai do nada e leva a lugar nenhum, e não é mais aceitável. Não inclui a história pessoal e social, não inclui o sofrimento psíquico, não abre possibilidades terapêuticas e, de fato, não explica nada.

Mesmo em uma tentativa de complexificar as explicações psiquiátricas, Gabbard (1992), em seu capítulo sobre TPAS, discorre muito mais sobre psiquiatria do que psicodinâmica. Grande parte de sua análise psicodinâmica busca bases biológicas para o transtorno, atribuindo à genética e a alterações neurológicas os problemas comportamentais. Posteriormente inclui que o genótipo modera a sensibilidade das crianças aos estressores ambientais, e as explicações neurobiológicas ainda insistem na tentativa de explicar esse mecanismo de defesa contra as falhas ambientais (Del-Bem, 2005). O autor segue explicando que os psicopatas têm uma grave falha na internalização do superego, e que isso leva a uma falta de moral que acaba sendo vista como falta de humanidade. Entrando nesse campo, nos faz refletir se a questão é imoral ou amoral, se eles não possuem moral ou escolheram não agir segundo a moral vigente. Caso fossem imorais, bastaria ensinar moralidade. Caso fossem amorais, existe algo mais complexo nessa vivência antissocial que explicações neurobiológicas, genéticas ou uma simples listagem de sintomas não dão conta.

Quando se trata de pessoas que cometeram crimes, perfis psicológicos e a interface da Psicologia com o Direito, outro pesquisador que fez um trabalho relevante foi Robert Hare, isso por sua dedicação a estudar "psicotapas". Em sua principal obra, Hare (1993) discorre sobre seus anos de estudo e da proposta de, diante inúmeros casos de crimes 
atribuídos a psicopatas, fazer uma distinção entre os verdadeiros psicopatas e aqueles que não eram. A concepção de Hare sobre os psicopatas é que eles não são mentalmente doentes e sim que seus atos são resultado de uma racionalidade fria e calculista combinada com a inabilidade de considerar os demais como pessoas que pensam e sentem. Sua preocupação não é apenas com assassinos cruéis, mas também com os psicopatas do dia a dia dada a sua capacidade de destruição. Sua observação de que psicopatas são pessoas como nós, parentes, vizinhos, colegas de trabalho é pertinente, porém considera apenas a dor sentida pelas vítimas, desconsiderando as vivências dos que perpetram a dor. Ao invés de serem "pessoas" como nós, acaba desenhando uma linha que separa os que sofrem dos que não sofrem.

A diferenciação entre loucura e maldade tem implicações práticas quando consideramos que diferentes instituições tomam a responsabilidade dependendo do foco. $\mathrm{E}$ para Hare a diferença implica se o tratamento e controle (sic) da psicopatia recai sobre os profissionais de saúde mental ou do sistema prisional. Se as ações são escolhas deliberadas de um desvio de caráter, a pessoa é diagnosticada, penalizada e excluída; se as ações são resultado de vozes ou desordens mentais, ela é diagnosticada, medicalizada e excluída. Qualquer que seja a razão dada como determinante de um ato, o desejo social de punição e exclusão parece ser o mesmo. A punição de crimes é sim importante, o que são olhados criticamente neste trabalho são as ideologias e os discursos sobre quem comete violência.

Dentre as diversas terminologias possíveis ao se falar do que poderia ser um TPAS, Hare (1993) utiliza a psicopatia para se referir a pessoas que quebram as leis e regras sociais por escolha deliberada, sem sentir culpa ou remorso, ignorando os demais como seres humanos. E justifica o uso deste termo, ao invés de sociopatia, por considerar que fatores psicológicos, biológicos e genéticos contribuem para esses comportamentos (enquanto os que usam sociopatia atribuem aos comportamentos forças sociais e 
experiências primárias). Essa concepção de homem explica a limitada solução de prender pessoas que rompem com a ordem, já que desconsidera o contexto familiar, social, político e econômico em que o sujeito se encontra. Ademais, seus escritos sobre psicopatia partem dos seus estudos e práticas com psicologia experimental e psicofisiologia cognitiva, e não incluem discussões sobre psicodinâmica, processos inconscientes, conflitos ou mecanismos de defesa. Para ele (Hare, 1993), os artigos que discutem a psicodinâmica da psicopatia não contribuíram para a sua compreensão, e atribui a isso a dificuldade de estudos empíricos sobre o tema.

Em se tratando de avaliação, um instrumento específico para pessoas que cometem atos de violência foi criado, garantindo não só o controle na listagem do que é ou não um requisito para uma condição psiquiátrica como controle também na forma como procurar e achar essas características específicas. Esse foi o resultado concreto do trabalho de Hare em sua pretensão de separar desvios sociais ou criminalidade dos psicopatas: a criação de um checklist de "psicopatia". A Psychophatic Check List - Revised, comumente chamada de PCL-R, foi criada por Hare e é o instrumento mais utilizado em Psicologia Forense na busca por discriminação de pessoas em "psicopatas” ou não.

A PCL-R é um instrumento composto de 20 itens baseados em sintomas-chave que "psicopatas" supostamente apresentariam, que são pontuados de zero a dois e levam a uma pontuação que se ultrapassada indicaria um "psicopata” típico (Hare, 1991). Os itens da Escala Hare, como também é conhecida, referem-se a traços pessoais e desvios sociais que o pesquisador acredita que eles apresentariam. Os traços emocionais e interpessoais incluem: loquacidade e superficialidade; egocentrismo e grandiosidade; falta de remorso ou culpa; falta de empatia; falsidade e manipulação; e emoções rasas. E os desvios sociais incluem: impulsividade; pobre controle comportamental; necessidade de excitação; falta de 
responsabilidade; problemas comportamentais desde cedo; e comportamento antissocial na vida adulta.

Assim como os critérios do DSM para o Transtorno de Personalidade Antissocial, os itens da Escala Hare podem ser identificados ao longo da vida de qualquer pessoa considerada comum, até mesmo um conjunto de vários itens, sem que isso se configure um problema. Variadas intensidades ou gravidades dentro de cada item poderiam ser o diferencial na identificação de um "típico psicopata", porém certamente pessoas "normais" também se aproximariam da pontuação que indica um "psicopata". O que gostaríamos de ressaltar com essas considerações é que uma lista de traços emocionais e situações sociais pode ser falaciosa na busca por antissociais.

Outro instrumento para avaliação em situação de violência é a HCR20 (Historical, Clinical and Risk Management Scale), elaborada por Webster e colaboradores (1995) na América do Norte e que é denominada assim por referir-se aos 20 itens históricos, clínicos e de risco investigados. Os itens históricos são: violência prévia, primeiro incidente violento em idade jovem, instabilidade nos relacionamentos, problemas empregatícios, problemas com uso de drogas, doença mental maior, psicopatia (resultado da PCL-R), desajustamento precoce, transtorno de personalidade, e antecedente de insucesso comportamental quando sob supervisão. Os itens clínicos incluem: falta de insight, atitudes negativas, sintomas ativos de doença mental maior, impulsividade, e falta de resposta ao tratamento. E os itens sobre gerenciamento de risco são: planos inexequíveis, exposição a fatores desestabilizadores, falta de apoio pessoal, não-aderência a tentativas de correção, e estresse (Abdalla-Filho, 2004).

Mais abrangente que a Escala Hare, a HCR20 investiga fatores passados, presentes e futuros que podem, juntos, representar risco de que uma situação de violência aconteça. Esse tipo de investigação mais abrangente favorece o compromisso ético com o processo 
avaliativo e o torna mais detalhado pois não se restringe a um ou outro possível fator de risco de violência, mas indica que esse fenômeno é melhor explicado e previsto quando um conjunto de fatores é observado. A diferença entre a PCLR e a HCR20 é que esta última investiga o risco de que uma ação violenta seja cometida, enquanto aquela foca na identificação de psicopatas. Entretanto, há muitos anos a questão do transtorno mental contribuindo para o comportamento violento vem sendo levantada e não está elucidada (Arboleda-Flórez \& Stuart, 2000), inclusive com considerações apontando para transtornos psiquiátricos serem fracos critérios para a avaliação de risco de violência (Harris \& Rice, 1997).

Um estudo realizado no Reino Unido para testar a eficácia da predição de violência da HCR20 foi feito com pacientes psiquiátricos liberados de unidades de segurança (Gray, Taylor \& Snowden, 2008). Os participantes eram homens submetidos à HCR20 com diversos diagnósticos (transtornos afetivo, de personalidade, psicóticos, induzidos por drogas, retardo mental e inclusive sem diagnóstico) que foram acompanhados após a liberação e incluídos no estudo caso tivesse cometido um crime violento. O resultado mostrou que os itens históricos e de gerenciamento de risco foram capazes de predizer o comportamento violento, enquanto os itens clínicos não produziram nenhuma predição estatisticamente significante. Outro resultado importante foi a eficácia da predição com o passar do tempo, pois quanto mais tempo se passava desde a liberação menos a HCR20 foi capaz de prever futuras violências.

Dois pontos interessantes podem ser extraídos desse estudo. O primeiro é o quanto variáveis clínicas, incluindo o diagnóstico de psicopatia, são superestimados na explicação e predição da violência. Comumente o foco volta-se para características negativas e "doentias" do autor do crime e esquece-se de considerar sua história pessoal, social e as reais possibilidades futuras. O outro ponto diz respeito ao alcance de predições avaliativas, 
pois o ambiente futuro não pode ser precisamente determinado e ele é parte da avaliação de risco. Avaliações apenas apontam possibilidades atuais e futuras e não podem ser tomadas como certeza preditiva, visto que são um recorte do momento presente do sujeito. Por mais úteis que o trabalho diagnóstico e avaliações sejam, eles precisam ser utilizados com parcimônia.

A tarefa diagnóstica, frequentemente, resulta em um nome que caracteriza o sujeito. Assim, junto com o nome, forma-se um discurso em torno dele que, infelizmente, passa a referenciar o sujeito em termos dessas características julgadas importantes. Ao falarmos de discurso não estamos nos restringindo às amostras de diálogo falado, mas sim ressaltando seu caráter de nomeação, interação e transformação do que é conceituado. De acordo com Fairclough (2008)

Os discursos não apenas refletem ou representam entidades e relações sociais, eles as constroem ou as 'constituem'; diferentes discursos constituem entidades-chave (sejam elas a 'doença mental', a 'cidadania' ou o 'letramento') de diferentes modos e posicionam as pessoas de diversas maneiras como sujeitos sociais (por exemplo, médicos ou pacientes), e são esses efeitos sociais do discurso que são focalizados na análise de discurso. Outro foco importante localiza-se na mudança histórica: como diferentes discursos se combinam em condições sociais particulares para produzir um novo e complexo discurso. (pg. 22)

A apreciação do poder do discurso é pertinente aqui devido à clara apropriação do diagnóstico que é feita pelos profissionais de referência em saúde, pela família, pela comunidade e, eventualmente, pelo próprio sujeito. Cria-se um discurso sobre o sujeito e sobre o que ele é ou não é a partir de uma classificação nosológica e então práticas se estabelecem. Sob um referencial de doença, discursos psicológicos e psiquiátricos são construídos e poderosamente transformam possibilidades de existência. Portanto, além do cuidado ético de responsabilizar-se pela decisão de submeter um indivíduo ao processo de psicodiagnóstico, há de se ter também esclarecido o que será feito com o resultado a que se chega, com essa psicopatologia utilizada na comunicação com outros profissionais da saúde, outras áreas e leigos que também se utilizarão da denominação. 
Uma tentativa de união da análise linguística e da teoria social lança luz diferenciada sobre discurso, uma vertente mais socioteórica sobre ele. Nesse contexto, um evento discursivo (incluindo fala e imagens visuais) é, ao mesmo tempo, texto, prática discursiva e prática social (Fairclough, 2008). Isto é, está sujeito a uma análise linguística de texto; como prática discursiva ressalta os processos de produção e interpretação textual, como por exemplo os tipos de discursos, suas derivações e combinações; e como prática social, a análise de discurso ocupa-se da análise social vinculada ao discurso, como as condições institucionais e organizacionais de onde surge o evento discursivo, como elas se ajustam à prática discursiva e os efeitos constitutivos do evento.

A atenção que Foucault deu à análise do discurso, preocupando-se com as práticas discursivas como constitutivas do conhecimento e com as condições de transformação do conhecimento em ciência, é de fundamental importância para uma teoria social do discurso. Seus estudos arqueológicos (Foucault, 1972) agregam tanto por verem o discurso como constitutivo dos objetos de conhecimento, sujeitos e formas sociais do "eu", relações sociais e estruturas conceituais, quanto por mostrarem a interdependência das práticas discursivas. Já seu trabalho genealógico (Foucault, 1979), foca em como o discurso, e seus indissociáveis processos sociais, está implicado nas modalidades de poder. Apesar das diferentes abordagens foucaultianas ao discurso ao longo de sua obra, elas juntas são úteis a essa nossa discussão sobre o fenômeno da violência e os discursos criados sobre o sujeito que comete violência.

Isso porque, primeiramente, ao falar do discurso como constitutivo e das regras para a constituição de áreas do conhecimento, Foucault dá ênfase a especificações sociais e históricas que permitiram a ocorrência de determinados enunciados que não seriam possíveis em outros tempos, lugares e contextos institucionais. O discurso sobre a psicopatia, por exemplo, só foi possível ser criado em um momento particular de 
patologização do delinquente. Além disso, a proposta foucaultiana sobre a formação de modalidades enunciativas (Foucault, 1972) mostra que o sujeito social que produz um enunciado não é uma entidade independente do discurso, mas função do próprio enunciado. Isso é importante para este trabalho pois posiciona os sujeitos em relação às suas práticas discursivas, mostrando que os discursos transformam os papéis sociais exercidos pelos indivíduos e que esses papéis são mantidos por complexas articulações sociais que obrigatoriamente passam pelo ato político expresso no discurso.

Em segundo lugar, ao perceber o potencial de poder contido nas formações e práticas discursivas, Foucault nos abriu os olhos para as relações entre os sistemas de conhecimentos e verdades, viáveis por meio do discurso, e os sistemas de poder, vistos como necessários para resolver o problema de controle das populações. $\mathrm{O}$ atual pacto entre os saberes psiquiátricos e psicológicos e os saberes jurídicos resulta em um poder do qual pessoas "perturbadoras da ordem" dificilmente escaparão. Esse poder é viabilizado pelos discursos produzidos por cada área do conhecimento e por tecnologias que sutilmente vão engolindo os sujeitos, e a eficácia do poder pode ser observada a medida que os sujeitos são moldados e reinstrumentalizados para se ajustarem ao sistema de poder.

As relações entre o discurso e o poder resultaram em formas políticas de manutenção ou modificação da apropriação de discursos, conhecimentos e poderes de determinadas instituições sociais. Existem restrições sobre o que pode ser dito, por quem e em que situação; criaram-se discursos opostos sobre razão e loucura, verdadeiro e falso. Sobre os controles sociais das práticas discursivas Foucault (1984) diz:

Em cada sociedade, a produção de discurso é imediatamente controlada, selecionada, organizada e redistribuída por um certo número de procedimentos, cujo papel é tutelar seus poderes e perigos, domesticar suas casualidades, escapar da sua ponderável, formidável materialidade. (pg. 109) 
A análise do discurso realizada por Foucault é valiosamente adicionada às considerações sobre o trabalho psicodiagnóstico por ressaltar o que não é atentamente visto em nossas práticas sociais cotidianas: a natureza constitutiva do discurso: ele constitui o social, seus objetos e sujeitos; a intertextualidade do discurso: práticas discursivas são definidas por suas relações com outras e de forma complexa; a natureza discursiva do poder: práticas e técnicas do bipoder são significativamente discursivas; a natureza política do discurso: a luta por poder acontece pelo discurso; e a natureza discursiva da mudança social: a mutação das práticas discursivas é vital para a mudança social (Fairclough, 2008).

Essas percepções são importantes porque quando falamos sobre uma pessoa que cometeu um ato de violência, o fazemos de um determinado lugar e com um objetivo. Pode-se falar de sua subjetividade, história familiar, dificuldades e potencialidades a partir da Psicologia. Ou de seu lugar social, seu crime e sua responsabilidade jurídica a partir do Direito. A questão que queremos destacar é que os discursos que elaboramos sobre alguém não se encerram em si mesmos, mas possuem repercussões que transformam a realidade daquele sujeito. O trabalho diagnóstico e as avaliações são bastante valiosos no trabalho dos psicólogos, visam o bem estar do sujeito. É importante, apenas, que essa postura de cuidado não se perca em detrimento de classificações nosológicas que silenciem subjetividades.

\subsection{O Método de Rorschach e suas outras possibilidades de avaliação psicológica}

A avaliação psicológica e o psicodiagnóstico surgiram no contexto clínico com a finalidade de compreender o funcionamento psíquico e fazer intervenções diante de dificuldades quando necessário, podendo assim minimizar o sofrimento do cliente e auxiliá-lo na conquista de seu bem estar. A fim de auxiliar no processo avaliativo, profissionais da Psicologia têm recorrido a instrumentos e técnicas específicas para ir a 
fundo na investigação, o que resulta em detalhamentos e particularidades psicodinâmicas que por outros caminhos dificilmente seriam alcançadas. Por seu valor em conhecer o mundo interno dos sujeitos, a avaliação e os instrumentos psicológicos passaram a figurar no contexto forense, subsidiando a tomada de decisão dos agentes jurídicos. Mesmo com objetivos diferentes, tanto no contexto clínico quanto no forense as exigências teóricas e técnicas dos profissionais são as mesmas, a fim de garantir a qualidade do trabalho, o cuidado com o cliente e a credibilidade do profissional de Psicologia perante o ambiente jurídico.

Como já sabido, são muitos os tipos de instrumentos psicológicos que podem enriquecer uma avaliação, utilizando-se de métodos diferentes como os psicométricos (por exemplo, os testes de inteligência), os gráficos (por ex., o desenho da Casa, Árvore e Pessoa - HTP) ou os projetivos (por ex., o Rorschach). Uma pesquisa com psicólogos forenses no Rio Grande do Sul (Rovinski \& Elgues, 1999) mostrou que 87\% deles utilizavam instrumentos psicológicos em seus trabalhos, com preferência para os projetivos e testes gráficos (especialmente HTP e Teste de Apercepção Temática - TAT). Outra pesquisa, realizada em São Paulo (Castro e Rocha Jr.,2004), mostrou que os psicólogos forenses preferem utilizar o HTP em avaliações no sistema penitenciário, justificando essa escolha pela facilidade de aplicação, baixo custo e rapidez na interpretação e análise, e não por pesquisas de validade do instrumento no contexto forense.

Em ambas as pesquisas supracitadas, o Rorschach foi citado como última escolha pelos psicólogos, que recorreriam a ele apenas quando uma avaliação profunda e dinâmica fosse necessária. Esse é um dado alarmante, que indica uma possível confusão na compreensão dos psicólogos forenses sobre o que se espera do seu parecer técnico naquele contexto jurídico e sobre a utilidade dos instrumentos psicológicos. Esses profissionais foram solicitados justamente para informar especificidades e fazer considerações 
aprofundadas sobre os acusados a partir de seu conhecimento teórico, técnico e ético. Trabalhos incompletos, superficiais e baseados em senso comum desrespeitam completamente as pessoas que têm suas vidas transformadas pelo resultado da avaliação psicológica. Um trabalho que não seja profundo, detalhado, crítico e personalizado para aquele sujeito e aquela demanda jurídica levanta sérias dúvidas sobre a competência do profissional e não deveria ser considerado no processo judicial do cliente.

É justamente profundidade que se busca quando um instrumento psicológico é incluído em uma avaliação psicológica. A fim de evitar a permanência nas trevas intelectuais, iremos nos debruçar um pouco mais no potencial que as técnicas projetivas e em especial o Método de Rorschach têm a oferecer à avaliação psicológica no contexto forense. Em suas pesquisas, Meyer, Erdberg e Shaffer (2007) verificaram que mesmo depois de cem anos da sua criação o Rorschach continua sendo um dos métodos mais úteis e proveitosos no estudo da personalidade.

O Rorschach é um método de investigação que gera dados que identificam diversos aspectos distintos tanto da estrutura quanto da dinâmica da personalidade. Por sua profundidade investigativa, é bastante apropriada ao trabalho clínico, mas também atende à demanda de psicodiagnóstico e diagnóstico diferencial. De acordo com Weiner (2000), pode-se dizer que a estrutura da personalidade é constituída pelos pensamentos e sentimentos atuais e as disposições mais duradouras que orientam as condutas, que seriam identificados como traços de personalidade. E a dinâmica da personalidade refere-se às atitudes, necessidades e conflitos por trás da maneira de pensar, sentir e agir do sujeito em momentos e circunstâncias específicas.

Este é um método investigativo pouco estruturado, por ser uma tarefa que parte de manchas de tinta, mas bastante organizado em sua codificação e amplo em suas possibilidades interpretativas. É um instrumento de avaliação tanto objetiva quanto 
subjetiva: a solução de problemas é um componente objetivo que exige estruturação cognitiva por meio da atenção, percepção e análise lógica e o estímulo à fantasia é o outro tipo componente, permitindo uma exploração idiossincrática através de processos de associação, atribuição e simbolização. A conceituação do instrumento como um teste está aquém da sua aplicação, pois testes tradicionalmente destinam-se a avaliar o grau em que construtos psicológicos estão presentes, e o Rorschach implica mais do que avaliações quantitativas como um teste. Além disso, o Rorschach não está vinculado a uma teoria específica, o que permite que seus dados sejam interpretados a partir de qualquer referencial teórico válido que discorra sobre o funcionamento da personalidade (Weiner, 2000). Sendo assim é mais apropriado referir-se a ele como um método de investigação. Essa adequação na terminologia não decorre de bases psicométricas duvidosas, pois quando administrado e codificado segundo o Sistema Compreensivo (Exner, 1999) atende a todos os requisitos psicométricos e demonstra validade e precisão em seus resultados (Shontz \& Green, 1992).

Em um estudo sobre a cientificidade das técnicas projetivas para avaliar a personalidade, Villemor-Amaral e Pasqualini-Casado (2006) discutiram os resultados das pesquisas no Brasil e demonstraram que o Rorschach no Sistema Compreensivo, quando comparado a técnicas como o Desenho da Figura Humana ou o Teste de Apercepção Temática, é o instrumento mais valorizado e estudado quando se trata de validação e normatização. Eles explicam que isso se deve ao prestígio que o Rorschach possui internacionalmente quanto à sua validade e confiabilidade e seu potencial singular para o processo psicodiagnóstico e planejamento de intervenções. Achados da literatura internacional (Gacono, Evans \& Viglione, 2008) mostram que, por suas propriedades psicométricas comprovadas e as características da sua investigação da estrutura e dinâmica da personalidade, o Método de Rorschach no Sistema Compreensivo tornou-se um dos instrumentos mais aceitos e utilizados nas avaliações forenses. 
A demanda ao profissional de Psicologia no contexto forense é complexa e exige um trabalho compromissado com o conhecimento teórico, técnico e ético para um bom resultado ao subsidiar decisões jurídicas. Um instrumento avaliativo completo como o Rorschach pode ser bastante útil para alcançar peculiaridades subjetivas sobre o acusado que vão além do diagnóstico, diferentemente de como outros instrumentos se restringem. $\mathrm{O}$ diagnóstico de psicopata tão procurado em situações de violência e que a PCLR se propõe a dar, por exemplo, diz muito pouco sobre a subjetividade do sujeito por prendê-lo a um nome frágil em explicações psicológicas sobre o mundo interno. Um discurso baseado no diagnóstico de psicopatia deveria sustentar-se em dados robustamente obtidos, como os instrumentos refinadamente construídos permitem, mas ao invés disso é obtido por uma lista de sintomas altamente sujeitos ao fenômeno da desejabilidade social e pouco discriminatórios acerca do construto que pretende avaliar.

As técnicas projetivas, segundo Chabert (2004) têm como objetivo permitir a investigação do funcionamento psíquico individual em uma perspectiva que leve em conta tanto as condutas psíquicas identificáveis como as singularidades e as potencialidades de mudança do sujeito. Essa apreciação é favorecida pela qualidade do material apresentado ao sujeito, que por ser simultaneamente concreto e ambíguo, permite verbalizações que conduzem à revelação de si mesmo. Aqui podemos perceber como a situação projetiva requer um funcionamento análogo à aceitação do paradoxo winnicottiano dos fenômenos transicionais, isto é, as manchas de tinta, no caso do Rorschach, são reconhecidas como triviais mas ao mesmo tempo sobre elas há um investimento de significações subjetivas. Há a criação de um cenário de representações e afetos íntimos que é admitido, consciente ou inconscientemente, pelo sujeito ao mesmo tempo em que ele responde à tarefa solicitada. 
A capacidade de brincar nesse espaço transicional e de estar em uma área de ilusão favorece o reconhecimento e a ampliação de um espaço psíquico próprio, constitutivo da continuidade de ser, que é preciso no estudo da personalidade. Chabert (2004) destaca ainda como as técnicas projetivas podem colocar em evidência, simultaneamente, elementos constitutivos de uma psicopatologia específica e as características mais individuais. Essa é uma corroboração importante na tentativa que fazemos aqui de nos desprendermos da lógica patológica de conotação negativa e voltarmos os olhares para as potencialidades que a subjetividade pode revelar nas avaliações psicológicas mais profundas.

Os tratamentos e métodos de investigação vêm se aprimorando na medida em que se observa que os funcionamentos mentais são bastante singulares, demandando um refinamento das técnicas e abordagens ao psiquismo que, ao mesmo tempo, sejam individuais em termos de respeito à subjetividade e abrangentes na inclusão da história pessoal, familiar e social como componentes daquela individualidade. Essa é uma tarefa a princípio paradoxal: utilizar um instrumento refinado o suficiente para identificar as potencialidade e dificuldades do sujeito, eventualmente até caracteres psicopatológicos, e também respeitar os movimentos do funcionamento psíquico que se apresenta, como nos lembra Chabert (1993). Felizmente o Rorschach é sensível o suficiente para perceber manifestações psíquicas que podem ser demasiado sutis para serem apreendidas por outros métodos de investigação, e o Sistema Compreensivo favorece uma decifração minuciosa das quantidades e qualidades dos conteúdos internos expressos na tarefa projetiva, que posteriormente serão interpretados com a abordagem teórica do profissional.

Geralmente quem se submete a uma avaliação psicológica está passando por algum tipo de sofrimento, o que erroneamente pode levar a uma tendência em focar nos aspectos 
negativos do sujeito. Sobre essa questão e os objetivos da interpretação de um Rorschach, Exner \& Sendín (1999) explicitam:

Um desafio que enfrenta quem interpreta o Rorschach é criar um quadro do indivíduo que seja suficientemente completo. Deve resumir os déficits, mas os enquadrando no contexto dos recursos. Deve enfatizar a integridade e o equilíbrio das operações internas, porém as situando no contexto dos intercâmbios com o meio externo. Não deve ser um amontoado de generalidades e frases banais, mas deve captar o essencial psicológico do sujeito e descrevê-lo como alguém que pode ser semelhante a outros indivíduos em uma série de aspectos, mas que, no fim, é único e diferente a todas as demais pessoas. (pg. 21)

O Rorschach no Sistema Compreensivo fornece dados ricos sobre o funcionamento psíquico do sujeito, e o faz em termos de organização interna e processos. Essa é uma característica importante pois sua contribuição é descritiva sobre o momento atual, o que impede, em grande parte dos casos, a obtenção de um perfil que corresponda diretamente às classificações diagnósticas do Manual Diagnóstico e Estatístico do Transtornos Mentais - DSM, ainda uma referência no campo psicodiagnóstico e forense. Os critérios do DSM utilizados nas categorias diagnósticas baseiam-se em autorelato e descrições de condutas, o que não corresponde às informações obtidas com os dados do Rorschach (Exner \& Sendín, 1999). Sendo assim, não deve haver precipitação na descoberta de evidências diagnósticas diretas entre seus dados. Além disso, dois sujeitos podem apresentar dificuldades de ajustamentos aproximadas e serem muito diferentes em suas dinâmicas psicológicas ou estruturas de personalidade.

Esta não é uma limitação do instrumento, e sim uma outra forma de abordar a psicopatologia. Os dados do Rorschach proporcionam informações gerais e específicas sobre traços de personalidade, contendo informações sobre processamento da informação, mediação cognitiva, ideação, controle e tolerância ao estresse, recursos afetivos, autopercepção e percepção interpessoal (Weiner, 2000). Seria equivocado esperar que as informações resultantes dessa investigação se organizassem em configurações padrão que classificassem os sujeitos em grupos de personalidade. O que a reunião dos dados permite 
é uma identificação de um estilo de personalidade, o que é suficiente e inclusive mais proveitoso no contexto forense do que um diagnóstico psiquiátrico clássico. Um rótulo que adjetiva uma pessoa que comete um ato de violência não diz nada sobre os processos subjacentes a este.

Esforços têm sido feitos por parte de psicólogos que trabalham tanto com psicoterapia quanto com avaliação psicológica em busca da clínica do Transtorno de Personalidade Antissocial, pois a tentativa do DSM de sustentar um modelo de desvio antissocial através de descrições comportamentais falhou. Nesse novo caminho, Gacono \& Meloy (1994), psicólogos com experiência em psicanálise com pessoas antissociais e com a população prisional e inclusive na administração da PCL-R, reconhecem que a pesquisa por conhecimento clínico passa por motivação, significado, organização de pensamento, vida afetiva, defesas, impulsos e relações; e que o Rorschach é uma excelente ferramenta para isso. Eles defendem também que tanto em contextos clínicos quanto de pesquisa, quando o sujeito for um paciente forense, o psicólogo evite o uso de instrumentos de autorrelato por observarem que os dados extraídos desse tipo de avaliação na população criminal são notoriamente não confiáveis (Hare, 1991).

O trabalho de Gacono \& Meloy (1994) focou na avaliação do Rorschach de personalidades agressivas e psicopáticas, estudando os protocolos de crianças, adolescentes, mulheres, homens, esquizofrênicos e homicidas considerados antissociais. Consideraremos os dados referentes aos homens adultos por ser esta a principal população carcerária nacional e internacionalmente. Em seus estudos, o Sistema Compreensivo foi complementado por uma análise psicodinâmica do protocolo. Seus resultados de pesquisa usam o termo psicopata por considerarem que conceitualmente este engloba características tanto de traço como de comportamento, diferenciando-o do Transtorno de Personalidade Antissocial que conceberia um critério apenas comportamental. 
Comparando os protocolos de Rorschach de pessoas com Transtorno de Personalidade Antissocial (considerados "psicopatas moderados" pelos pesquisadores) e de pessoas tidas como "psicopatas severos" (encarceradas e alcançando a nota de corte da PCL-R para psicopatia), alguns resultados importantes foram ressaltados. Gacono \& Meloy (1994) concluíram que o narcisismo e a histeria são traços de personalidade que determinam a severidade e a expressão da psicopatia, após analisarem as variáveis conteúdo humano, pares, reflexos, índice de egocentrismo e resposta pessoal. Analisando a superficialidade do afeto, a baixa reatividade e a dificuldade na capacidade para vínculos, observaram que a autocrítica negativa não foi diferente entre os dois grupos. A necessidade de proximidade/capacidade para vínculos e o sentimento de desamparo foram menos frequentes no grupo de psicopatas; e a capacidade de manter o controle foi levemente menor no grupo de psicopatas moderados. As respostas agressivas não foram discriminativas entre os grupos na análise do alcance e intensidade do impulso agressivo.

As respostas às manchas de tinta do Rorschach são codificadas no Sistema Compreensivo de forma a se transformarem em variáveis e índices, que são reunidos de acordo com a interrelação entre eles que auxilia na elucidação das dinâmicas e estruturas que compõem o funcionamento psíquico; e esses grupos de variáveis e índices reunidos são denominados agrupamentos (Exner, 1999). Como já citado, os agrupamentos do Rorschach são: processamento de informações, mediação cognitiva, ideação, afeto, autopercepção, relações interpessoais e controle e tolerância ao estresse. A seguir, será relacionada uma breve comparação entre alguns agrupamentos importantes para essa discussão observados entre o grupo de psicopatas moderados (TPAS) e o grupo de psicopatas severos na pesquisa de Gacono \& Meloy (1994) quando estes foram comparados com grupos de não pacientes (Tabela 1). 
Tabela 1. Características em alguns agrupamentos do Rorschach dos sujeitos que apresentam Transtorno de Personalidade Antissocial (TPAS) e que apresentam psicopatia (Gacono \& Meloy, 1994)

\begin{tabular}{lll}
\hline Agrupamento & TPAS & Psicopatia \\
\hline Afeto & $\begin{array}{l}\text { Pouca modulação afetiva; evitação de } \\
\text { estímulos emocionais; estilo de } \\
\text { oposição e negativismo; afetos } \\
\text { disfóricos; sentimento de desamparo }\end{array}$ & $\begin{array}{l}\text { Modulação afetiva mais pobre; maior } \\
\text { evitação de estímulos emocionais; } \\
\text { sentimento de desamparo. }\end{array}$ \\
Relações interpessoais & $\begin{array}{l}\text { Não esperam cooperação dos demais; } \\
\text { pouca interação agressiva; condutas } \\
\text { de dependência; percepção da figura } \\
\text { humana de forma parcial ou } \\
\text { fantasiada; pouca necessidade de } \\
\text { proximidade/capacidade de formar } \\
\text { vínculos. }\end{array}$ & $\begin{array}{l}\text { Ligeiramente menor expectativa de } \\
\text { cooperação; ligeiramente menor } \\
\text { interação agressiva; ligeiramente } \\
\text { menor dependência; levemente maior } \\
\text { percepção fantasiada da figura } \\
\text { humana; menor necessidade de } \\
\text { proximidade/capacidade de formar }\end{array}$ \\
vínculos.
\end{tabular}

Essa pequena tabela foi apresentada apenas com o objetivo de ilustrar, desmistificar e contribuir de maneira mais apurada para uma sensível aproximação ao sofrimento pelo qual essas pessoas passam em seu mundo interno. Obviamente nem todas as características psicológicas observadas nessa pesquisa pertencem à subjetividade de todos os antissociais, e as diferentes interrelações entre elas no psiquismo de cada um resultam em funcionamentos muito particulares. Qualquer generalização ou estigmatização seria precipitada e irresponsável.

Um agrupamento que não foi detalhado por Gacono \& Meloy (1994) é o de controle e tolerância ao estresse, apesar de ser essencial na discussão sobre psicopatia e violência. Este agrupamento é composto, entre outros, por um dos índices encontrados em 
grande parte dos protocolos aplicados por mim, o CDI (do termo em inglês Coping Deficit Index): Índice de Inabilidade Social, e será explicado para posterior discussão com a teoria winnicottiana do amadurecimento emocional e ampliação na concepção da participação individual no fenômeno da violência.

Situações que exigem uma tomada de decisão sobre o que pensar e como se expressar são constantes na vida das pessoas; seja em ambiente de trabalho ou na vida pessoal, continuamente é preciso solucionar problemas. Regularmente na vida diária as pessoas estão envolvidas com tomada de decisão e resolução de problemas, demandas que surgem internamente, como pensamentos e sentimentos, ou externamente, como a interação com o que as outras pessoas falam e fazem. Independente da origem, essas demandas se constituem um estresse devido à necessidade de serem atendidas de alguma forma para que o bem estar pessoal e funcionamento efetivo sejam alcançados, como ressalta Weiner (2000). Quanto mais adequado for $\mathrm{o}$ atendimento às demandas experenciadas, maior a chance de sucesso ao manejar o estresse e de um bom ajustamento psicológico. Caso haja dificuldades em satisfazer as demandas, considera-se que há um fracasso no manejo do estresse que implica em dificuldades adaptativas.

No Rorschach, um dado valioso no estudo das dificuldades em lidar adequadamente com o estresse, afetos e relações interpessoais é o Índice de Inabilidade Social - CDI. Esta é uma medida amplamente fundamentada dos recursos adaptativos que o sujeito possui para lidar com as demandas da vida diária. De acordo com Exner \& Sendín (1999), a presença de CDI no protocolo de Rorschach interage com o campo das relações interpessoais assinalando problemas para enfrentar eficazmente as demandas comuns de seu meio social, indicando inaptidão ou déficit para o que é relacional. E interage com o controle e tolerância ao estresse sinalizando que o sujeito terá dificuldades no manejo de muitas situações devido às suas vivências de desamparo mais intensas que o habitual, o 
que provoca comportamentos bastante similares aos manifestados em situação de sobrecarga.

O CDI é composto de variáveis que referem-se à quantidade de recursos disponíveis, controle, qualidade das relações interpessoais, processamento deliberado das emoções, responsividade emocional, percepção da figura humana, necessidade de proximidade e capacidade para vínculos, envolvimento em relações sociais, ingenuidade e condutas dependentes. Ele é um dado significativo apenas quando positivado (CDI igual ou maior que quatro condições presentes), sendo pouco importante quando não está elevado. A grande maioria de não-pacientes de todas as idades apresenta um CDI pontuando três ou menos, o que serve de parâmetro para as análises dos protocolos de Rorschach (Exner, 1999)

O aparecimento de algumas condições para o CDI mas que não o pontue como positivo indica que há recursos adequados para um funcionamento de competência razoável mas não está associado, necessariamente, à presença de uma personalidade excepcional nem exclui a possibilidade de dificuldades no ajustamento. Entretanto um CDI positivo marca claramente dificuldades adaptativas e que os sujeitos tentam lidar com as experiências comuns do cotidiano ineficaz e inadequadamente. Weiner (2000) alerta que as implicações de um CDI alto são mais especificadamente entendidas se obervado o nível da Experiência Efetiva - EA do sujeito, uma variável do Rorschach que integra as capacidades afetivas e ideacionais para a adaptação.

O EA é um indicativo da competência psicológica, relativo ao volume de recursos que o sujeito dispõe para planejar e implementar estratégias frente às demandas de tomada de decisão e resolução de problema; e quanto maior for sua pontuação, melhor. A inadequação apontada por um CDI alto, quando acompanhada de um EA baixo, caracteriza pessoas com limitada competência psicológica, que tem vários aspectos da vida afetados 
pela inabilidade e que provavelmente tiveram poucos êxitos educacionais, ocupacionais e interpessoais. Já um quadro de CDI alto acompanhado de EA também alto geralmente é observado em pessoas que não se mostram incompetentes na vida geral, obtiveram realizações significativas mas que apresentam grande dificuldade em administrar suas relações interpessoais gratificante e confortavelmente (Weiner, 2000).

Além de distinguir os padrões de inadequação no modo de enfrentamento das demandas, outra faceta do CDI é sua sensibilidade na identificação de formas de depressão que não são marcadas por afeto disfórico ou cognições negativas, mas sim por desamparo persistente (Exner \& Weiner, 1995). O CDI por si só não pode ser considerado como diagnóstico de transtornos afetivos, porém aproximadamente $80 \%$ dos diagnosticados com transtornos afetivos por outros instrumentos apresentarão um CDI elevado. Outras condições psicológicas em que haja manifestação de desamparo e insucesso no enfrentamento das demandas da vida frequentemente também apresentarão um alto CDI, como por exemplo pessoas que abusam de álcool e outras substâncias e pessoas com transtorno de caráter, especialmente os envolvidos com problemas com o sistema judiciário.

A análise do Índice de Inabilidade Social em dois agrupamentos do Rorschach e sua riqueza de detalhamento demonstram sua importância no funcionamento psíquico humano, pois é um índice que reverbera em dois âmbitos fundamentais na vida: o manejo do estresse e o manejo das relações com os demais. Esses são, relembrando, elementos frequentemente discutidos quando o assunto é violência e as pessoas que cometem violência. Investigar as dificuldades e possibilidades nesses aspectos é, portanto, essencial na compreensão da qualidade das relações do indivíduo e na sua capacidade de iniciar e manter a direção de suas condutas. 
De acordo com Weiner (2001, apud Rovinski 2011), o Rorschach permite o levantamento de informações que refletem disposições e atitudes mais duradouras no tempo, e em um contexto forense a descrição de traços de personalidade fundamenta as discussões sobre previsibilidade de conduta de maneira mais ampla. De certo um psicólogo não pode garantir que um comportamento futuro irá ou não ocorrer, mas a indicação de que determinados comportamentos tendem a acontecer dentro de padrões e contextos daquela história pessoal justifica as inferências de uma forma menos irresponsável.

O Método de Rorschach possibilita novas formas de avaliação no contexto forense, rompendo com o paradigma que dicotomiza normalidade e anormalidade, bom e mau, certo e errado e entende o sofrimento com novo olhar. Classificações psicopatológicas, se utilizadas irresponsavelmente, podem impedir a apreciação do funcionamento psíquico, resultando em medidas jurídicas e intervenções psicológicas equivocadas. A personalidade tão buscada nos perfis psicológicos de pessoas que cometem crimes não é uma entidade alheia ao sujeito como os rótulos de "psicopata", "monstro" e demais alcunhas levam a crer. Um estilo de personalidade é fruto de um psiquismo composto de recursos e dificuldades, potencialidades e fragilidades, amor e ódio. Está associado a uma subjetividade que não se configurou com alguns elementos ou outros, mas sim com a soma de todas as suas vivências pessoais, familiares e sociais em um contexto histórico, econômico e político.

O Rorschach é um instrumento de investigação que buscar identificar as manifestações psíquicas mais discretas e seus lugares dentro da organização psicológica do sujeito, na liberdade de expressar a si mesmo que a situação projetiva permite, sem $a$ prioris ou determinações pré-estabelecidas. A verdade sobre si que o sujeito pode contar na proteção de uma avaliação psicológica responsável, e favorecido por uma técnica projetiva, possui valor inestimável, tanto no contexto clínico quanto no contexto forense. É difícil 
conceber processos judiciais e medidas jurídicas de responsabilização, que contem com a contribuição da Psicologia, sem que a realidade da subjetividade do sujeito seja verdadeiramente levada em consideração.

Não deixando espaço para dúvidas, o trabalho diagnóstico e as avaliações psicológicas são positivos, úteis e valiosos. A utilização do Rorschach nas avaliações psicológicas forenses pode ampliar a discussão sobre a violência e pessoas que cometem atos de violência devido à sua apreciação diferenciada do funcionamento psíquico. Quando se compreende que a expressão comportamental possui elementos subjacentes que envolvem afeto, ideação, autopercepção e interpessoalidade, a violência deixa de estar descolada da subjetividade. Dentro de uma história pessoal específica, a organização psicológica pode acontecer de formas mais ou menos adaptadas, com maiores ou menores chances de se expressar por meio da violência. Porém é inegável que a expressão da subjetividade por meio da violência só pode ser explicada no contexto específico daquele sujeito, e que essa forma de se colocar para o mundo pode acontecer com qualquer pessoa. 


\title{
Capítulo 4: O Índice de Inabilidade Social e a Tendência Antissocial: um olhar de base winnicottiana sobre o fenômeno da violência
}

\author{
A clínica do cotidiano nos permite constatar que, efetivamente, \\ uma série de paradigmas e valores de nossa sociedade, circunstâncias que se mantiveram \\ relativamente estáveis no decurso de várias \\ gerações que nos antecederam, estão sendo contestados, modificados \\ e, mesmo, substituídos por outros muito diferentes.
}

José Outeiral (2007)

Como viemos defendendo, a violência é um fenômeno social presente no cotidiano de forma bastante peculiar, pois chama cada indivíduo que compõem a sociedade a se posicionar devido ao impacto que causa em cada um particularmente e convoca um posicionamento enquanto comunidade pois forças maiores que cada indivíduo se manifestam na reação à violência. Já a agressividade, conceito diferente da violência, mobiliza subjetivamente e socialmente os sujeitos por ser um dos componentes do psiquismo a partir do qual se constroem as relações humanas.

Faz parte da nossa responsabilidade enquanto construtores da sociedade nos incluirmos no fenômeno da violência, sendo assim, além de procurarmos maneiras de interromper o ciclo precisamos aceitar que a expressão violenta não é exclusiva de um ou outro indivíduo. Partindo daí, o estudo da agressividade e de outras características do funcionamento psíquico pode ser um caminho privilegiado para uma discussão diferenciada do tema da violência dentro da Psicologia e para uma nova abordagem social dos problemas que ela causa, visto que as atuais estratégias de enfrentamento estão falhando.

A agressividade não é inerentemente negativa, essa associação só se naturaliza quando ela é confundida com violência. Segundo Vilhena (2002), a agressividade seria, ao mesmo tempo, um movimento do eu na demarcação da identidade quando esta é ameaçada pelo outro e também um pedido de reconhecimento por esse outro. Enquanto que a 
violência promove a desqualificação do valor identitário do outro, exacerbada pelo narcisismo que desequilibra as relações entre o sujeito e o outro. A qualquer sinal de diferença, não satisfação ou não reconhecimento, a ampliação de mecanismos narcísicos remete a experiências primordiais de impotência e desamparo, o que pode resultar em reações violentas. Nessa situação de ameaça ao eu, as reações de segregação, antagonismo e ódio ao diferente se acentuam, tornando as pequenas diferenças insuportáveis.

A dificuldade em separar a agressividade de sua conotação negativa provavelmente está relacionada ao reconhecimento de que podemos ser agressivos e também podemos inibir nossos impulsos agressivos, cindindo os dois processos psíquicos e deslocando a agressividade para aqueles que cometem atos de violência. Admitir que o mesmo sujeito que pode proteger aqueles que ama de sua agressividade pode também machucar com seus impulsos agressivos parece socialmente inconcebível, mas Klein (1935) e Winnicott (1939) já elucidaram como esses processos de destruição e proteção têm suas bases na voracidade (termo que expressa a fusão original de amor e ódio) do bebê, que busca satisfação mas acaba sendo cruel e doloroso por acaso.

Essa conciliação entre satisfazer-se suficientemente e evitar ser excessivamente perigoso na busca por essa satisfação nem sempre é alcançada, e não é uma questão que está em pauta nas discussões sobre assassinato, por exemplo. Na vida infantil, sentir-se satisfeito acarreta colocar em perigo o que se ama, porque na fantasia inconsciente a destruição é real e constante. Dependendo dos cuidados iniciais com o processo de amadurecimento psíquico, na vida adulta a fantasia de destruição mágica ainda pode ser causa de angústia quando se trata da integração amor-ódio. Na conciliação que visa uma gratificação menos perigosa, muitas vezes o sujeito se frustra e consequentemente volta o ódio para si, a menos que, como bem lembra Winnicott (1939), ele encontre alguém fora de si que se encarregue da frustração e que suporte ser odiado por isso. 
O outro, além de participar da integração da agressividade no psiquismo por sua função de diferenciação, também pode assumir um papel de amparar o ódio do sujeito e fornecer a frustração que ele precisa para descarregar seus instintos agressivos - que todos precisam descarregar, mas nem sempre encontram estratégias saudáveis e socialmente aceitas. Quando essas forças internas destrutivas duelam com as forças internas de amor, o sujeito se vê obrigado a tentar salvar-se desse conflito, e geralmente dramatizar esse mundo exterior é a sua saída (Winnicott, 1939). Representar externamente o dilema interno permite assumir o papel destrutivo, já que o controle será exercido por um outro. É uma resolução psiquicamente viável, mas não por isso fácil, como o psicanalista observa:

Ser capaz de tolerar tudo o que podemos encontrar em nossa realidade interior é uma das grandes dificuldades humanas, e um dos importantes objetivos humanos consiste em estabelecer relações harmoniosas entre as realidades pessoais internas e as realidades exteriores. (pg. 98)

Existem histórias pessoais complexas que se somam a contextos sociais desfavoráveis resultando em realidades difíceis de lidar de forma harmoniosa. Há solicitações internas e externas que não são compatíveis com o desenvolvimento do amadurecimento emocional pelo qual a pessoa passou e com os aspectos práticos do cotidiano, que podem esbarrar em dificuldades sociais concretas, como desemprego, fome, falta de moradia e saúde. A sobreposição das características pessoais com o seu papel no mundo complexifica a expressão violenta de alguns sujeitos e quebra com a lógica binária de que as pessoas são boas ou ruins, negando a elas o reconhecimento de uma subjetividade que se manifesta na sociedade de forma muito particular.

Quando as pessoas não conseguem equilibrar suas realidades interna e externa como a sociedade acha correto ou normatiza, elas são consideradas antissociais. Elas se tornam o bode expiatório que concentrará toda a violência existente em suas mãos, o que será resolvido quando ela morrer ou for isolada do convívio social. Acontece que essa é 
uma postura que ignora que a tendência antissocial se manifesta na relação com o outro, e essa estratégia de exclusão e privação de liberdade apenas pune e não resolve o problema que a violência causa. A tendência antissocial compele o meio ambiente a ser importante (Winnicott, 1956). Mesmo que o encarceramento seja a última medida para salvar o sujeito, sem tratamento adequado e longe de seus pares, dificilmente um sujeito poderá desenvolver formar saudáveis de equilibrar as demandas internas e externas. O cuidado com o ambiente desse sujeito - família, comunidade, escola, entre outros - também precisa ser considerado.

O desenvolvimento emocional que favorece o aparecimento da tendência antissocial revela que houve um trauma decorrente da relação entre o meio ambiente e o sujeito; sendo assim, a questão do antissocial diz respeito essencialmente ao que é relacional. Relacional é também um aspecto essencial do Índice de Inabilidade Social levantado pelo Método de Rorschach. Uma teoria de personalidade e um método de investigação psicológica, então, podem juntos olhar para o que se refere à agressividade, à "psicopatia" e ao fenômeno da violência de forma personalizada e humanizada.

Partindo então dessa convergência de achados teóricos e técnicos, o aspecto relacional da vida das pessoas passa a ser o ponto chave no entendimento do fenômeno da violência. A Psicologia é uma área privilegiada para fazer essa discussão pois é capaz de acessar fragilidades no campo relacional, seja por uma avaliação psicológica auxiliada por um método de investigação sensível, como o Rorschach, seja por um processo psicoterápico baseado em uma teoria que inclua como segundo protagonista o meio ambiente em que acontece o processo de amadurecimento emocional, como a teoria winnicottiana. Fazendo uma analogia com a conclusão de Winnicott (1986) de que não existe um bebê sem sua mãe, podemos considerar que não há uma pessoa violenta sem um contexto relacional que a explique. 
As informações obtidas pelo Método de Rorschach não só são profundas no sentido de desvelar a personalidade, mas explicam como os diversos aspectos do psiquismo interagem para formar uma subjetividade única. Especificamente o Índice de Inabilidade Social pode mostrar como, por exemplo, uma pessoa que não qualifica as relações interpessoais como hostis tem sérias dificuldades sociais. Isso porque dificuldades relacionais não são medidas tendo apenas a agressividade como referencial (Exner \& Sendín, 1999), mas considerando inclusive a vivência de outros afetos, como o sujeito percebe a si mesmo, percebe seu lugar em relação ao mundo externo, como tolera o estresse que esse mundo lhe impõe e como seus processos cognitivos lhe auxiliam no enfrentamento do cotidiano.

Mesmo em casos que não envolvam violência pode-se verificar a inabilidade social, pois ela também se expressa de maneira sutil e indiretamente, como em fraco desempenho acadêmico ou dificuldades de concentração (Weiner, 2000). Em casos como esses, as dificuldades podem ter origem na incoerência quanto ao modo de lidar com as experiências ou em um estresse situacional, por exemplo. Caso a experiência estressante torne-se muito urgente e não possa ser resolvida de imediato, ou o sujeito a perceba como impossível de solucionar, a vivência de impotência provoca uma sobrecarga significativa, e isso interfere em seu funcionamento.

Em casos de violência, a inabilidade social parece ficar mais evidente, pois ela se expressa diretamente nas relações interpessoais. E isso chama a atenção das pessoas ao redor de quem comete a violência e de quem a sofre naquele momento, o que frequentemente requer intervenção, seja da polícia e dos operadores do Direito, seja de profissionais de saúde e das áreas psis. Quando o sujeito não tolera as demandas internas e externas e percebe a ameaça ao seu self (Winnicott, 1960), ele pode falhar em sua 
habilidade para utilizar seus recursos disponíveis, formular e realizar suas decisões e agir em favor de si mesmo (Exner \& Sendín, 1999).

Essa é uma consideração de base psicológica complexa, mas que pode ser incorporada pelos profissionais da área jurídica. Ocorre que seres humanos perdem o controle quando se veem sem saída ou quando estão afetivamente sobrecarregados. Seres humanos se desorganizam quando possuem poucos recursos e muitas demandas externas para dar conta. Seres humanos não se ajustam bem ao meio social quando estão vulneráveis à impulsividade ideativa ou afetiva e precisam lidar com uma vivência crônica de desamparo. Provavelmente por isso os antissociais sejam atacados em sua humanidade por algumas pessoas, porque é insuportável conviver com a ideia de que seres humanos vivem sua subjetividade de forma complexa e podem falhar ao ter que responder às demandas sociais.

Ademais, quando eu reconheço que outro ser humano é passível ao erro, acabo entrando em contato com meu próprio erro. Quando alguém quebra as regras sociais, ao mesmo tempo em que por um momento desejamos fazer o mesmo ou nos lembramos que quebramos de forma semelhante, também fica no ar que a regra foi criada por um motivo. A perversão, segundo Roudinesco (2008), apenas existe enquanto eliminação, enquanto confronto da ordem; é um fenômeno sexual, político, social, psíquico, trans-histórico e estrutural observável em todas as sociedades humanas. Por sua qualidade psíquica, que alude à clivagem, pode-se compreender a perversão como uma necessidade social, o que corrobora a discussão que vem sendo feita sobre a relação do antissocial com o meio ambiente.

Nesta asserção, especificamente, é interessante notar que a função da perversão é preservar a norma e simultaneamente delimitar e assegurar a existência dos prazeres e transgressões (Roudinesco, 2008). Só é preciso designar a perversão como uma 
transgressão ou anomalia porque ela é desejável, porque ela condena a quem se permite um gozo ilimitado. Isso seria incompatível com a manutenção da ordem social, exigindo que as sociedades compartilhem regras, através, por exemplo, da proibição de algumas práticas sexuais, da demarcação da loucura e da nomeação do monstruoso. Ainda segundo a psicanalista, os perversos, bodes expiatórios da vez, são os personagens perfeitos que traduzem em atitudes singulares as tendências mais secretas e inconfessáveis que todos possuem e trabalham arduamente para recalcar. Sendo assim, não há como negar que os perversos são uma parte de nós mesmos, que expõem a negatividade presente no humano e por isso incomodam tanto.

Assim como é mais fácil identificar uma possível inabilidade social em casos de violência, é nítido como muitos desses casos dizem respeito a falhas ambientais. O sujeito atua sua agressividade no âmbito relacional a fim de chamar o ambiente a posicionar-se em relação a ele. Concordamos que não é a maneira mais saudável de fazer um alerta, mas é uma forma, que se dada a devida atenção, é bastante informativa das dificuldades que o sujeito está enfrentando e de como ele ainda está vivo na busca de sua harmonia interna e externa. A tendência antissocial implica esperança (Winnicott, 1956), esperança de que o meio se faça importante e responda à perda ambiental precoce que o sujeito sofreu. É na esperança que a tendência se apresenta, afinal o sujeito não é antissocial o tempo todo. Quando o sujeito percebe que o ambiente pode responder à deprivação que sofreu, age de maneira antissocial como em um pedido de socorro, para que aqueles ao seu redor movimentem-se ao encontro desse momento de esperança e correspondam a ele.

Paradoxalmente, a forma como o meio responde a esse pedido de ajuda para lidar com a deprivação sofrida é privando ainda mais o sujeito. A tendência antissocial caracteriza-se por um desapossamento, ou seja, a perda de algo positivo na vivência emocional que se estendeu por um tempo maior do que se pode manter viva a lembrança 
da experiência (Winnicott, 1956). Essa condição traumática no processo de amadurecimento, obviamente, impacta o desenvolvimento dos traços afetivos e das relações interpessoais, elementos importantes na análise da inabilidade social feita no Método de Rorschach.

O ambiente falha novamente com o sujeito. Falha gravemente ao não acolher e administrar a expressão violenta da agressividade que se coloca frente a um trauma anterior e falha ao favorecer a repetição do trauma por meio da nova privação. Segundo Winnicott (1956), é o provimento de cuidados o caminho para o tratamento da tendência antissocial; cuidados raramente encontrados em prisões ou manicômios judiciários. A estabilidade do novo suprimento ambiental é o elemento fundamental, explica o psicanalista, ao indicar que é o ambiente que deve dar nova oportunidade à ligação egóica, uma vez que o sujeito percebe que foi um trauma ambiental que redundou originalmente na tendência antissocial.

Essa tendência, que pode começar a se manifestar na infância, acompanha o sujeito até a vida adulta caso o ambiente insista em desperdiçar o momento de esperança, e a Justiça pode acabar sendo a última alternativa de controle por meio de uma autoridade externa. Entretanto, é difícil imaginar como uma história pessoal marcada por falhas e traumas possa fornecer ao sujeito recursos psicológicos para ajudá-lo a manejar o estresse, que Weiner (2000) aponta como determinantes para a qualidade da adaptação a si mesmo e ao ambiente, da forma que o judiciário espera e em situação de encarceramento.

A tentativa de explicação do fenômeno da violência com o discurso de que as pessoas são "más por natureza" trás à discussão a tentativa de identificar algo que está sempre presente e que poderia motivar atos antissociais. Os debates sobre a origem da violência podem também localizá-la no ódio, o que acaba sendo menos senso comum, a menos que ele seja adjetivado como inerentemente irracional e patológico. Conforme 
Arendt (1994), o ódio não é uma reação à miséria ou ao sofrimento; seu surgimento se dá onde houver razões para suspeitar que as condições poderiam ser mudadas e não são. Somente onde o senso de justiça for ofendido é que a reação será o ódio. Acrescenta ainda que a violência é tentadora quando se enfrentam acontecimentos ou condições ultrajantes devido à sua proximidade e rapidez de "solução", e, mesmo que essa rapidez seja contraditória à essência do ódio, isso não a torna irracional - argumento amplamente utilizado na desumanização de pessoas que agem violentamente.

Umas das grandes mudanças que o paradigma winnicottiano trouxe foi uma nova forma de compreender a etiologia e a natureza dos distúrbios dos quais a psicanálise vinha se ocupando. Em sua perspectiva do amadurecimento, Winnicott pensa os distúrbios como modificações da elaboração imaginativa criativa do vir ao mundo e do ser no mundo (Loparic, 2010). Isto é, perturbações no início dos relacionamentos do sujeito com o mundo externo ou dos relacionamentos já estabelecidos, relacionamentos esses que têm base nos estados somáticos e são dirigidos primeiramente ao ambiente e secundariamente aos objetos. Assim sendo, a qualidade dos relacionamentos com o ambiente guiará as condições de possibilidades dos relacionamentos objetais.

$\mathrm{O}$ atendimento às necessidades nas fases iniciais permite conquistas importantes para que o indivíduo torne-se um ser existente, ou seja, conquistas que constituem a estrutura de personalidade. Traumas do ambiente nessas fases iniciais levam à aniquilação do ser, e em fases mais a frente, à perda da capacidade de existir no mundo e ser alguém. Depois das conquistas que levam à constituição do $e u$ sou, a nova necessidade é adquirir a capacidade de tolerar a ambivalência causada pela presença de relacionamentos amorosos e agressivos, tarefa que será facilitada pelo acolhimento ambiental dessa ambivalência e pela oferta de um código externo de comportamento, que transformará a angústia e a culpa em responsabilidade e tolerância dos elementos agressivos nos impulsos amorosos 
(Winnicott, 1958). E a próxima necessidade é a preservação do ambiente suficientemente bom, que quando percebido como retirado da experiência do sujeito por fatores externos, leva à tendência antissocial.

Essa mudança paradigmática casa muito bem com a atual necessidade de compreender os seres humanos fora de um binarismo bom/mal, normal/anormal, haja vista que essas visões superficiais não têm auxiliado a estes nem os que são impactados por suas ações violentas. A ênfase no processo, na continuidade de ser, no amadurecimento, faz a diferença na compreensão das fragilidades de relacionamento que o sujeito pode vir a apresentar. A tentativa de acomodar a experiência de perda que a tendência antissocial representa só pode ser compreendida sob a luz da tendência à integração, que demanda do sujeito em amadurecimento suportar as demandas e expectativas do ambiente imediato e relacioná-las com as complexidades de seu desenvolvimento (Loparic, 2010).

A teoria winnicottiana do amadurecimento deixa muito claro que não existe uma fragilidade relacional que surja sem interrupções na continuidade de ser específicas que a contextualizem, assim como seria impossível buscar psicopatologias no Rorschach desconsiderando a conjunção de vulnerabilidades psíquicas que favorecem seu aparecimento. O Método de Rorschach é um instrumento de investigação do funcionamento estrutural e dinâmico da personalidade (Weiner, 2000), ou seja, uma forma de conhecer os elementos subjetivos que constituem um sujeito ele mesmo. Nessa investigação, podem se apresentar indícios de dificuldades mais sérias no processo de integração e em que área do funcionamento essas dificuldades repercutem com maior intensidade (áreas do funcionamento que remetem aos agrupamentos do Rorschach), o que não transforma o instrumento em um detector de psicopatologias, justamente porque a subjetividade de cada indivíduo é muito maior que isso. 
O Índice de Inabilidade Social do Rorschach é a reunião de diversos componentes psicológicos que podem levar a dificuldades na área relacional da vida do sujeito, mas não constitui um distúrbio ou psicopatologia. Uma das grandes contribuições do Rorschach ao desenvolver esse método foi precisamente possibilitar uma investigação da personalidade sem que isso se associasse necessariamente a enquadramentos psiquiátricos e referenciais psicológicos de anomalia. Como especificam Exner \& Sendín (1999), as informações sobre ideação, emoções, percepção interpessoal, autopercepção, estratégias defensivas, estilo de resposta, resolução de problemas que podem ser levantadas falam de organização interna e processo, sendo descritiva a melhor contribuição do Rorschach.

Por não ser uma psicopatologia, a inabilidade social pode ser entendida como uma dificuldade de ajustamento, mas ainda sim uma característica psicológica passível de ser manifestada por qualquer pessoa. Quando saímos da perspectiva da patologia, uma nova possibilidade de olhar para as pessoas em sofrimento psíquico se abre e nos aproximamos do que Winnicott compreendia como ser total. Os conflitos internos são compreendidos por ele como perturbações na existência psicossomática, o que considera o sujeito na sua totalidade e na sua história, na qual estão incluídas as aquisições do seu desenvolvimento desde o início (Winnicott, 1945). Esse sujeito, então, não é um ser que pensa e consequentemente tem sua existência comprovada pelo pensamento; mas sim um sou, um ser somático elaborado imaginativamente que com o passar do tempo se tornará um eu sou, um indivíduo total.

É com esse indivíduo total que nos relacionamos, não com sua inadaptação ou patologia. É esse ser total que pode falhar no manejo do estresse e nas habilidades sociais, perturbar a ordem social, descarregar sua agressividade de forma violenta, ser responsabilizado judicialmente e acabar condenado moralmente e excluído do convívio social. Porém nada podemos saber sobre seu contexto pessoal e como tomar decisões 
legais para punir seu comportamento antissocial sem antes conhecer justamente esse ser total.

Infelizmente, para garantir que a punição seja efetiva aos que transgridem a ordem, tanto na punição judicial quanto na social, a totalidade e a humanidade dos sujeitos algumas vezes têm sido deixadas de lado. Em seu lugar, criam-se discursos que caracterizam negativamente aquele que deixou de ser humano e passou a ser acusado. $\mathrm{O}$ poder do discurso em transformar a vida de determinados sujeitos apoia-se na sua característica de prática social, ou seja, o discurso não é uma atividade puramente individual ou reflexo de variáveis situacionais (Fairclough, 2001). Uma das implicações imediatas desse fato é que o discurso torna-se um modo de ação, uma forma das pessoas poderem agir sobre o mundo e especialmente sobre os outros. Outra implicação é a relação dialética entre o discurso e a estrutura social, e sobre isso o linguista explica:

O discurso contribui para a constituição de todas as dimensões da estrutura social que, direta ou indiretamente, o moldam e o restringem: suas próprias normas e convenções, como também relações, identidades e instituições que lhe são subjacentes. $\mathrm{O}$ discurso é uma prática, não apenas de representação do mundo, mas de significação do mundo, constituindo e construindo o mundo em significado. (pg. 91)

Portanto, a construção do discurso do mal, a criação do personagem "psicopata" e todo o potencial de destruição a ele associado configura-se uma formação discursiva que contribui para a construção de um papel social específico, para a construção de relações sociais entre as pessoas baseadas no medo e para a construção de sistemas de crenças que qualifiquem o indivíduo de acordo com as características que a sociedade considera indesejáveis. Esses aspectos dos efeitos construtivos do discurso correspondem às funções identitária, relacional e ideacional da linguagem (Fairclough, 2001) e asseguram que o imaginário social possa repousar em um personagem concreto em sua sede de "justiça".

O discurso é uma prática social que tem como uma de suas orientações a prática política e ideológica (Fairclough, 2001). Como prática ideológica, ele constitui, naturaliza, 
mantém e transforma os significados do mundo nas relações de poder, como por exemplo a afirmativa de que todos os antissociais são criaturas violentas e perigosas. Como prática política, ele estabelece, mantém e transforma as relações de poder e as entidades coletivas entre as quais existem relações de poder, por exemplo, as relações de poder entre psicólogos e psiquiatras e os antissociais. Ambas as práticas são interdependentes, pois ideologia são os significados gerados em relações de poder como exercício e luta pelo poder.

A reflexão crítica, a responsabilidade e a ética são fundamentais nas nomeações, categorizações e discursos praticados cotidianamente, visto que a prática discursiva lança mão de convenções que naturalizam relações de poder e ideologias particulares para a manutenção de uma estrutura social determinada. Estrutura social essa que, muitas vezes, visa qualificar pessoas que cometem atos de violência como monstros e eliminá-los, impedindo sua participação social e luta pelo poder. A maioria das convenções sociais, impostas e asseguradas por certas instituições, serve justamente para isso: para determinar quais papéis sociais os indivíduos podem assumir, o que estão autorizados a dizer, como devem se portar e por onde podem circular; sempre com o objetivo de manter o privilégio de alguns e a submissão de outros.

As práticas mais comuns de submissão geralmente envolvem o corpo, apesar de usá-lo com um intermediário para atingir algo que não é propriamente o corpo. As prisões, a reclusão, os trabalhos forçados e a deportação, por exemplo, são penas físicas, onde o corpo é colocado em um sistema de privação, coação, obrigações e interdições. O papel da dor no corpo na constituição das penas foi se transformando em meados do século XIX, apesar de não ser totalmente extinta, haja vista que os castigos baseados na privação pura e simples de liberdade precisam de complementos punitivos referentes ao corpo para potencializarem seus efeitos (Foucault, 1979). Os objetos jurídicos (crimes e delitos) 
continuam a ser julgados, porém julgam-se também paixões, instintos, efermidades, inadaptações, reações ao meio ambiente e hereditariedade. Quando as violações são punidas, é preciso considerar que se punem também a agressividade, os impulsos e os desejos.

Julga-se o juridicamente não codificável: o conhecimento do criminoso; o que se aprecia nele; o que se sabe sobre a relação entre ele, o seu passado e o crime; o que se pode esperar de seu futuro. $\mathrm{Na}$ verdade, então, os atuais processos jurídicos e as consequentes condenações são formas de qualificar um indivíduo, e não apenas sancionar uma infração. Busca-se controlá-lo e neutralizar sua periculosidade por meio de medidas apoiadas em um saber médico-jurídico e nesse momento o laudo psiquiátrico encontra uma de suas funções: dar aos mecanismos de punição legal um poder justificável sobre os indivíduos, e não mais sobre as infrações. Não sobre o que eles fizeram, mas sobre o que eles são, serão ou possam ser.

O aparelho jurídico, recorrendo à disciplina, procura um corpo dócil que possa ser submetido, utilizado, transformado e aperfeiçoado (Foucault, 1979). Para isso, utiliza uma política de coerções, trabalhos sobre o corpo, manipulação calculada dos elementos, gestos e comportamentos através de técnicas específicas e detalhadas que tem como intuito disciplinar. O poder disciplinar tem como função maior adestrar as multidões confusas, móveis, inúteis de corpos e forças, tendo como característica importante o aumento das forças do corpo por meio da utilidade econômica e a diminuição dessas mesmas forças através da obediência política; o que define uma nova forma de investimento político sobre os sujeitos.

O sucesso do poder disciplinar se deve ao uso de instrumentos simples como a vigilância, a sanção e o exame. Explica Foucault (1979) que a vigilância domina fisicamente os corpos; a sanção regulamenta e normaliza, individualizando e 
homogeneizando; e o exame combina as técnicas da hierarquia que vigia e da sanção que normaliza, qualificando, classificando e punindo. Um lugar privilegiado para implementar esses instrumentos de submissão dos transgressores é a prisão (e suas modalidades derivadas, como o manicômio judiciário). Por sua vigilância e conhecimento dos detentos, a prisão transformou-se em um local de formação para um saber clínico sobre os condenados. Assim, o sistema cria o delinquente, sobre o qual importa qualificar cientificamente e que difere do criminoso comum pela caracterização da sua vida ligada ao crime. As medidas punitivas recaem não sobre a autoria de um crime, mas sobre a afinidade do criminoso com seu crime. Portanto, a prisão é o lugar onde o poder de punir organiza um campo de objetividade em que o castigo funciona como terapêutica e a sentença aparece entre os discursos do saber.

$\mathrm{Na}$ tentativa de reestabelecer a ordem social e fazer justiça, frequentemente violências são cometidas. Sobre a falta de proteção às pessoas em sofrimento psíquico que cometeram um crime, Costa (2004) aponta:

Há que se afirmar que os abandonos humanos, sociais, profissionais e estatais dos indivíduos denominados de doentes mentais que cometeram crimes tornam o nosso País, um dos que, não admitindo a prisão perpétua formalmente, mantém essa prática de forma escamoteada, escondida aos olhos da sociedade porque encarcerada e escondida, perpetra toda sorte de violência aos direitos humanos do indivíduo assim chamado, desrespeitando seus direitos mais fundamentais, qual seja o de ter oportunidade de se cuidar e de se tratar. Não se trata aqui, como apressadamente se pode concluir, de se buscar uma 'mera liberação do doente mental', mas antes de respeitar os seus direitos humanos mínimos diante dessa condição, inclusive o se ser honestamente tratado. Assim, urge organizar mobilizações, questionamentos e práticas profissionais e sociais que apontem para a mudança desta "sentença muda, cega e surda". (pg. 98)

O Rorschach de pessoas consideradas antissociais ressalta o caráter relacional das dificuldades que algumas enfrentam em sua vida diária, visto que o que está em destaque em sua inabilidade social são características relacionadas ao meio externo: tolerância à frustração e relações interpessoais. O que corrobora com a proposta winnicottiana de compreensão da personalidade que coloca o meio ambiente como fundamental no processo 
de amadurecimento emocional, explicitando que pessoas que apresentam tendência antissocial perderam algo bom que tiveram em suas vivências e chamam justamente quem retirou essa experiência positiva delas - o meio ambiente - a comparecer de forma acolhedora e cuidadosa no reestabelecimento de sua continuidade de ser (Winnicott, 1956).

Portanto, não é por acaso que a teoria de Winnicott e o Método de Rorschach tenham sido trazidos para este trabalho sobre violência e pessoas que cometem violência. Cada um contribui enormemente para uma discussão mais aprofundada sobre o tema, um por sua abordagem não patologizante do antissocial e o outro pelas informações detalhadas e personalizadas que fornece em uma avaliação psicológica, respectivamente. Juntos têm o grande potencial de favorecer reflexões diferenciadas sobre o fenômeno da violência e seus atores.

Assim sendo, a avaliação psicológica, o acompanhamento clínico, as decisões jurídicas e talvez o julgamento social daqueles que cometem atos de violência podem se transformar com a consideração de que eles são pessoas como quaisquer outras, mas que enfrentam dificuldades relacionais. Com a consideração de que pessoas em sofrimento psíquico que cometem violência são antes de tudo pessoas. E, como pessoas, são também seus afetos, pensamentos, desejos e sonhos em um contexto pessoal, familiar, cultural, histórico, econômico e político específicos, porém fragilizadas e vulneráveis, que encontraram um caminho para a sobrevivência psíquica por meio da expressão violenta de sua rica, complexa e única subjetividade. 


\section{Considerações finais}

Existem atos de violência nos mais diversos contextos e pelos mais variados motivos, desde guerras e suas disputas por territórios, revoluções e suas reivindicações por outros panoramas sociais até assassinatos para tomada de controle no tráfico de drogas. $\mathrm{O}$ que se procurou discutir neste trabalho foram os atos de violência e a ocorrência de crimes no cotidiano da sociedade brasileira, onde grande parte deles se dá na esfera interpessoal

ou de maneira estrutural. A não especificação em termos de violência contra a mulher ou contra os jovens, cometida por homens ou pelas forças policiais foi deliberada a fim de que a discussão sobre o fenômeno da violência pudesse ser ampliada para diversos contextos. De forma alguma o objetivo foi minimizar a ocorrência de certo tipos de violência em detrimento de outros, mas sim que pudéssemos levar as considerações aqui feitas para reflexões em situações específicas, considerando sua pertinência.

No imaginário social, a violência está associada à marginalidade, a atos físicos de abuso e à ruptura das normas e leis. E isso é inconcebível dentro da fantasia que a sociedade criou para ela mesma de ser cordial, não violenta e sem preconceitos, onde os episódios de violência são uma exceção e os mecanismos de exclusão social estão aí para resolvê-los. O que uma observação lúcida da atual realidade brasileira mostra é que nos expressamos por meio da violência sim. Dificuldades sociais, econômicas e políticas não podem ser minimizadas como panorama maior que inflama ações violentas. Já em outros contextos, a falta de habilidades sociais pode ser vista acompanhando atitudes violentas. Então, é preciso assumir que somos uma sociedade que está bastante confortável em lançar mão da violência como forma de comunicação e expressão pessoal antes de qualquer coisa, para que em seguida reflexões e medidas coletivas possam ser discutidas a fim de que os danos causados por essa estratégia sejam minimizados - tanto na vida dos que sofrem quanto na vida dos que cometem violência. 
Obviamente ninguém é a favor de que a violência seja o principal meio de expressão da agressividade, considerando que essa forma é bastante maléfica, tanto no micro quanto no macro espaço. A não ser as pessoas que lucram com o mercado que se desenvolve ao redor da violência, como a indústria de armas, de instituições encarceradoras, os sistemas de segurança pública e privada, a mídia e todos os investidores desses polos geradores de dinheiro. Ou os grupos sociais que visam o extermínio daqueles que são os alvos preferenciais de atos violentos, como por exemplos as mulheres e os negros; aqueles também não estão preocupados com o fim da violência.

É preocupante ver, inclusive nas rodas de debates organizadas contra a violência, como o combate à violência é defendido. $\mathrm{O}$ uso da palavra combate indica bem as intenções, de que se combata violência com mais violência, de que se reforce o policiamento e a vigilância e de que mais prisões sejam construídas. Isso não diminui a violência, são apenas medidas tomadas depois que ela já aconteceu. Quem sabe, com as atuais discussões sobre o tema, não possamos pensar em como evitar que a violência aconteça através de melhores condições sociais e econômicas e do aprendizado de maneiras mais saudáveis de nos relacionarmos.

Os profissionais envolvidos com a saúde mental, aqui em especial os psicólogos, agregam positivamente no grupo dos que clamam por tempos menos violentos devido sua aproximação diferenciada ao que diz respeito ao humano e sua conduta comprometida com aqueles em sofrimento psíquico. Dentro desse compromisso está o de defender que nenhum instrumento ou teoria psicológica pode ser utilizado para reforçar estereótipos. Uma subjetividade é muito maior do que informações levantadas em avaliações psicológicas, maior do que um conjunto de características convencionalmente associadas a pessoas violentas. É essencial não cair no erro de perverter os conhecimentos psicológicos importando teorias maniqueístas que pretendem dividir o mundo entre bem e mal, entre 
pessoas boas e ruins. Caso isso aconteça, estaremos apenas cometendo violências e silenciando subjetividades com respaldos supostamente científicos. Profissionais da saúde mental e da Psicologia não podem legitimar medidas discriminatórias e ideologias socialmente excludentes, mas sim utilizar seus conhecimentos em prol de uma sociedade saudável, integradora e funcional.

A decisão de refletir sobre violência a partir de pessoas que a cometem neste trabalho reflete uma preocupação com um dos elementos participantes no fenômeno da violência. Uma discussão sobre violência que não inclua esses atores pode sofrer de falta de complexidade. Obviamente entendemos que recortes dentro do grande tema da violência são necessários a fim de otimizar problematizações específicas, políticas públicas de cuidado e intervenções mais acuradas. $\mathrm{O}$ recorte feito neste trabalho visa somar nos debates e na união de forças que buscam acabar com a violência cotidiana, e não enfraquecer os movimentos nacionais e internacionais nessa direção. Este recorte de forma alguma buscou invisibilizar outras vítimas de violência e outras lutas, como as fundamentais reivindicações do movimento negro e do movimento feminista, por exemplo. A existência desses grupos é essencial para assegurar a defesa da democracia e participação social na busca de uma sociedade mais harmônica. E a existência de grupos que se preocupam com os que cometem violência reconhecendo que esses o fazem porque sofrem - seja em nível psíquico, familiar, social, econômico e/ou político - não invalida outras lutas.

A finalidade desta dissertação foi, não deixando espaço para dúvidas, chamar atenção para as violências estruturais que as pessoas que cometem violência sofrem e para os absurdos que vivem após agirem violentamente, incluindo nessa discussão propostas psicanalíticas que acolhem e elucidam sobre a expressão antissocial e refletindo sobre as posições psicológicas que se assumem acerca dessas pessoas. Finalidade esta que se alinha 
com a ideologia da não-violência, visto que a atenção a essas pessoas tem grande potencial para interromper o ciclo da violência, através da inclusão de seus contextos sociais e pessoais no tema e dos cuidados psicológicos que eles necessitam para ressignificarem sua existência. Um posicionamento de não-violência só pode ser efetivo quando defende os direitos de todos os humanos, só pode ter um amplo alcance quando se reconhece a humanidade, as necessidades e as possibilidades de todos, indiscriminadamente.

Desenvolvimentos futuros no que concerne ao conhecimento e à técnica na Psicologia precisam acontecer dentro do tema violência, colocando o respeito ao humano como norteador de suas teorias e práticas. Dentro do tema, os estudos futuros sobre avaliação psicológica de pessoas que cometem violência podem partir do uso crítico de testes psicológicos e de classificações diagnósticas que não enclausurem os sujeitos em rótulos vazios de subjetividade. Inclusive uma pesquisa mais aprofundada sobre os componentes do Método de Rorschach seria acadêmica e socialmente relevante, tanto para a própria Psicologia quanto para sua aplicação em outras áreas do conhecimento. E esperase que os estudos psicológicos estejam a serviço do bem estar e saúde mental das pessoas, que possamos promover a liberdade de ser ao invés de preconceitos.

Uma consideração que não pode deixar de ser feita em se tratando de violência é a questão racial que a atravessa, tanto quando falamos de quem sofre violência quanto de como é tratado quem a comete dependendo da cor de sua pele. Enquanto mulher negra, não posso e não fecharei os olhos para a violência que sofre toda a comunidade negra no Brasil, mesmo tendo me proposto a estudar pessoas que cometem violência. Por vivenciar e presenciar as crueldades pelas quais passam os negros diariamente em nosso país, e sabendo da dinâmica cíclica da violência, considero importante que as expressões violentas da agressividade também recebam atenção da Psicologia a fim de que também deixemos de ser vítimas - em todos os sentidos. 
Apesar de sermos maioria na população brasileira, os negros ainda são minoria em força social e política e vêm sendo exterminados há décadas. Há uma amnésia seletiva no que se refere ao nosso passado escravocrata nem tão distante e à nossa constituição fenotípica, histórica, cultural e econômica através dos negros. Esse esquecimento tornou-se discriminação e a crença de que um grupo racial poderia ser dominante em relação a outro, o que é facilmente verificado atualmente com a perseguição policial a jovens negros, por exemplo. O Mapa da Violência no Brasil de 2012 mostra que o número de homicídios de jovens negros foi de 17499 para 23160 entre 2002 e 2012, enquanto os homicídios de jovens brancos caíram 32,3\%. Esse é apenas um exemplo do genocídio negro que acontece no país desde sua "descoberta", termo que precisa ser utilizado visto que genocídio é definido como sendo crime contra a humanidade e que consiste em matar membros de um grupo nacional, étnico, religioso ou pertencente a determinada raça, com o fim de destruição total ou parcial desse grupo.

Em se tratando de pessoas que cometem violência, é perceptível a diferença de tratamento jurídico e social que ocorrem dependendo da cor da pele do acusado, mesmo que isso não seja reconhecido e inconstitucional. Uma pessoa branca que comete um crime muitas vezes é tratada como louca, fora de seu estado normal ou como um caso isolado de um momento de descontrole. A loucura entra em cena e a questão vai para o campo da circunstancialidade, das condições momentâneas sob as quais o sujeito estava. Como se pessoas da pele clara fossem inerentemente boas independente de qualquer coisa. Então a sociedade é benevolente com aquele pequeno deslize, e nos casos de assassinatos mais chocantes, o autor do crime é alçado ao posto de serial killer com tons de deslumbramento ao estilo celebridade rock star.

Já quando o crime é cometido por uma pessoa negra, logo seu caráter é colocado em questionamento, e as considerações envolvem a falta de moral, o ato deliberadamente 
cometido como uma mostra de sua essência má. Como se as pessoas de pele escura estivessem inerentemente propensas a serem ruins e agirem contra a moral e os bons costumes, transformando aquele bode expiatório em um degenerado, monstro, escória da sociedade que não merece ser considerado ser humano. E assim o único caminho que uma sociedade que se diz justa e clama por paz vê como possível é o seu extermínio, seja ele físico ou social. Então o ciclo continua e sofremos todas as violências imagináveis, uma vingança travestida de justiça plenamente legitimada e executada pelo Estado.

É fato que, independente da cor de sua pele, quem comete violência invariavelmente a sofre em consequência. A consideração racial feita aqui não se dirige a valorizar mais uma ou outra situação, mas a apontar as distintas qualidades de julgamento que podem acontecer. É inadmissível que o ciclo da violência se multiplique e perpetue, e interrompê-la passa por impedir que ela se volte para quem a cometeu, seja negro ou branco. Inserir o racismo e as diferenças sociais nas ações voltadas a essa interrupção permitiria um cuidado mais específico para proteger os que já sofrem injustiças incalculáveis simplesmente por terem a pele negra; o que fica inclusive como sugestão de recorte para trabalhos futuros. 


\section{Referências bibliográficas}

Abdalla-Filho, E. (2004). Avaliação de risco de violência em psiquiatria forense. Rev Psiquiatr Clin, 31(6), 279-83.

Adorno, S. (2002). Exclusão socioeconômica e violência urbana. Sociologias, 4(8), 84135.

APA. (2013). Manual diagnóstico e estatístico de transtornos mentais: DSM-V. Porto Alegre: Artes Médicas.

Aquino, S. T. D. (2005). Sobre o mal. Tradução Carlos Ancêde Nougué. Rio de Janeiro: Sétimo Selo.

Arboleda-Flórez, J., \& Stuart, H. L. (2000). The future for risk research. The Journal of Forensic Psychiatry, 11(3), 506-509.

Arendt, A. (1994). Sobre la violencia. Tradução de André Duarte. Rio de Janeiro: Relume Dumará.

Avoglia, H. R. C. (2012). O sentido da avaliação psicológica no contexto e para o contexto: uma questão de direito. Psicólogo inFormação16.16: 179-190.

Bakthin, M. (1979). Marxismo e filosofia da linguagem. São Paulo: Hucitec.

Barros, C. S. M. (2011). Aplicação da política de saúde mental instituída pela lei $n$. 10.216/2001 ao louco infrator. Revista de Criminologia e Ciências Penitenciárias. Conselho Penitenciário do Estado - COPEN.

Barros-Brisset, F. O. (2011). Genealogia do conceito de periculosidade. Responsabilidades, 37.

Bauman, Z. (1997). Ética pós-moderna. Trad. de João Rezende Costa. São Paulo: Paulus.

Bauman, Z. (2004). Amor líquido: sobre a fragilidade dos laços humanos. Rio de Janeiro: Jorge Zahar.

Bauman, Z. (2007). Vida líquida. Rio de Janeiro: Jorge Zahar.

Brasil (1984). Lei n. ${ }^{\circ}$ 7.210, de 11 de julho de 1984. Institui a Lei de Execução Penal. Diário Oficial da União, Poder Executivo, Brasília. 
Brasil. (1988). Constituição da República Federativa do Brasil. Brasília: Senado Federal.

Brasil (1990). Lei n. ${ }^{\circ}$ 8.080, de 19 de setembro de 1990. Dispõe sobre as condições para a promoção, proteção e recuperação da saúde, a organização e o funcionamento dos serviços correspondentes e dá outras providências. Diário Oficial da União, Poder Executivo, Brasília.

Brasil (1990). Lei n. ${ }^{\circ} 8.142$, de 28 de dezembro de 1990. Dispõe sobre a participação da comunidade na gestão do Sistema Único de Saúde - SUS e sobre as transferências intergovernamentais de recursos financeiros na área da saúde e dá outras providências. Diário Oficial da União, Poder Executivo, Brasília.

Brasil. (2001). Lei 10216 de 06 de abril de 2001. Dispõe sobre a proteção e os direitos das pessoas portadoras de transtornos mentais e redireciona o modelo assistencial em saúde mental. Diário Oficial da União, Poder Executivo, Brasília.

Brasil. (2010). Código Penal. São Paulo: Saraiva.

Brasil. (2014). Portaria Interministerial n..$^{\circ} 1$ de 2 de janeiro de 2014. Ministério da Saúde, Brasília.

Brasil. (2014). Portaria n. ${ }^{\circ} 94$ de 14 de janeiro de 2014. Ministério da Saúde, Brasília.

Brasiliense, D. R. (2009). Os vestígios da monstruosidade na feitiçaria e na loucura e os discursos contemporâneos da mídia sobre os sujeitos criminosos. Revista Fronteiras estudos midiáticos,11(2), 123-136.

Bruno, A. (1984). Direito Penal: $4^{a}$ Edição. Rio de Janeiro: Forense.

Castro, P. F., \& Rocha Jr, A. (2004). A (não) utilização do Método de Rorschach no Sistema Penitenciário de São Paulo. Técnicas projetivas: Produtividade em pesquisa, 401404. Em: $3^{\circ}$ Congresso Nacional da Sociedade Brasileira de Rorschach e métodos projetivos, 2004, Porto Alegre. Programação e resumos dos trabalhos.

CFP. (2005). Código de Ética do Psicólogo. Resolução CFP n. 010/05. Aprova o Código de Ética Profissional do Psicólogo. Disponível em: http://www.pol. org.br/pol/export/sites/default/pol/legislacao/ legislacaoDocumentos/resolucao2005_10.pdf

Chabert, C. (1993). A psicopatologia no exame de Rorschach. São Paulo: Casa do Psicólogo.

Chabert, C. (2004). Psicanálise e métodos projetivos. São Paulo: Vetor. 
Cordioli, M. S., Borenstein, M. S., \& Ribeiro, A. A. D. A. (2006). Hospital de custódia: os direitos preconizados pela reforma psiquiátrica e a realidade dos internos. Escola Anna Nery.

Costa, E. W. K. A. (2015). A falência da medida de segurança: da exclusão à alteridade. 2015. 330 f., il. Tese (Doutorado em Psicologia Clínica e Cultura)-Universidade de Brasília, Brasília.

Costa, I. I. (2004). A doença mental no contexto dos direitos humanos e da violência. Em: Maluschke, G., Bucher-Maluschke, J. S. N. F., \& Hermanns, K. Direitos humanos e violência: desafios da ciência e da prática. Fortaleza: Fundação Konrad Adenauer.

Cunha, J. A. (2000). Psicodiagnóstico-V. Porto Alegre: Artmed.

Dahlberg, L. L., \& Krug, E. G. (2006). Violência: um problema global de saúde pública. Ciênc. saúde coletiva, 11(supl), 1163-1178.

Dalgalarrondo, P. (2008). Psicopatologia e semiologia dos transtornos mentais. Porto Alegre: Artmed.

Davoglio, T. R., \& Argimon, I. I. D. L. (2010). Avaliação de comportamentos anti-sociais e traços psicopatas em psicologia forense. Avaliação Psicológica, 9(1), 1111-118.

Del-Ben, C. M. (2005). Neurobiologia do transtorno de personalidade anti-social. Revista de Psiquiatria Clínica, 32(1), 27-36.

Dias, E. O. (2000). Winnicott: agressividade e teoria do amadurecimento. Natureza humana, 2(1), 9-48.

Diniz, D. (2013). A custódia e o tratamento psiquiátrico no Brasil: censo 2011. Brasília: Letras Livres/Editora Universidade de Brasília.

Exner, J. E., JR. (1999). O Rorschach: um sistema compreensivo, volume 1: fundamentos básicos. São Paulo: Casa do Psicólogo

Exner, J. E., JR \& Weiner, I. B. (1995). The Rorschach: A Comprehensive System. Vol. 3. Assessment of children and adolescents. New Jersey: John Wiley and Sons.

Exner, J. E., JR \& Sendín, C. (1999). Manual de Interpretação do Rorschach para o Sistema Compreensivo. São Paulo: Casa do Psicólogo.

Fairclough, N. (2001). Discurso e mudança social. Trad. Izabel Magalhães. Brasília: Editora Universidade de Brasília. 
Foucault, M. (1972). A arqueologia do saber. Rio de Janeiro: Forense Universitária, 2007.

Foucault, M. (1979). Vigiar e punir: A história da violência nas prisões. Petrópolis: Vozes, 2010.

Foucault, M. (1984). A ordem do discurso. São Paulo: Loyola, 2001.

Foucault, M. (2002). Os anormais. São Paulo: Martins Fontes.

Foucault, M. (2004). A evolução da noção de “indivíduo perigoso” na psiquiatria legal do século XIX. Ética, sexualidade, política (Coleção Ditos \& Escritos, Vol. 5, pp. 1-25). Rio de Janeiro: Forense Universitária

Freud, S. (2011). O eи е o id (1923). Obras Psicológicas de Sigmund Freud, 13-93.

Gabbard, G. (1992). Psiquiatria psicodinâmica na prática clínica. Porto Alegre: Artmed.

Gacono, C. B. \& Meloy, J. R. (1994). The Rorschach assessment of aggressive and psychopathic personalities. New Jersey: Lawrence Erlbaum Associates.

Gacono, C.B.; Evans III, F.B. \& Viglione, D.J. (2008) Essencial issues in the forensic use of the Rorschach. In: C.B. Gacono \& B. Evans, The Handbook of Forensic Rorschach Assessment (pp 3-20). New York: Routledge.

Girard, R. (2011). Aquele por Quem o Escândalo Vem. São Paulo: É Realizações Editora.

Godsi, E. (2004). The globalisation of violence. In: Godsi. E. (Ed.). Violence and society: making sense of madness and badness. UK: PCCS Books.

Goffman, E. (2008). Manicômios, prisões e conventos. São Paulo: Perspectiva.

Graña, R. B. \& Outeiral, J. O. (1994) Apresentação à Edição Brasileira em Explorações Psicanalíticas. Trad. José Octávio de Aguiar Abreu. Porto Alegre: Artes Médicas.

Gray, N. S., Taylor, J., \& Snowden, R. J. (2008). Predicting violent reconvictions using the HCR-20. The British Journal of Psychiatry, 192(5), 384-387.

Haddock-Lobo, R. (2006). Da existência ao infinito: ensaios sobre Emmanuel Levinás. São Paulo: Loyola.

Hare, R. (1991). The revised psychopathy checklist. Multi-Health Systems, Toronto.

Hare, R. (1993). Without Consciense. EUA: Guilford Press. 
Harris, G. T. \& Rice, M. E. (1997). Risk appraisal and management of violent behavior. Psychiatr Serv 48(9):1168-75.

Hisada, S. (2001). Clínica do Setting. Rio de Janeiro: Revinter.

Hisada, S. (2011). Conversando sobre psicossomática. Rio de Janeiro: Revinter.

Khan, M. (1958). Prefácio. Em: Winnicott, D. W. (1993). Textos Selecionados - da Pediatria à Psicanálise. Rio de Janeiro: Francisco Alves.

Klein, M. (1935). A contribution to the psychogenesis of manic-depressive states. The International Journal of Psychoanalysis.

Lebre, M. (2012). Medida de segurança e periculosidade criminal: medo de quem?. Responsabilidades, Belo Horizonte, 2(2), 285-301.

Levinas, E. (1987). No identity. In Collected Philosophical Papers (pp. 141-151). Springer Netherlands.

Loparic, Z. (1999). É dizível o inconsciente?. Natureza humana, 1(2), 323-385.

Loparic, Z. (2001). Esboço do paradigma winnicottiano. Cadernos de história e filosofia da ciência, 11(2), 7-58.

Loparic, Z. (2010). Winnicott clínico. Natureza humana, 12(2), 1-26.

Mecler, K. (2010). Periculosidade: Evolução e aplicação do conceito. Revista brasileira de crescimento e desenvolvimento humano, 20(1), 70-82.

Meyer, G.J.; Erdberg, P.; Shaffer, T.W. (2007). Toward international normative reference data for the Comprehensive System. Journal of Personality Assessment, v. 89, n.S1, p.201206.

Minayo, M. D. S. (1994). A violência social sob a perspectiva da saúde pública. Cadernos de saúde pública, 10(1), 7-18.

Neto, O. C., \& Moreira, M. R. (1999). A concretização de políticas públicas em direção à prevenção da violência estrutural. Ciência \& Saúde Coletiva,4(1), 33-52.

Outeiral, J. (2007). Família e contemporaneidade. Jornal de Psicanálise,40(72), 63-73.

ONU (1948). Declaração Universal dos Direitos Humanos. Disponível em http://nacoesunidas.org/declaracao-universal-dos-direitos-humanos/. Acessado em 21/11/2015. 
Pastana, D. R. (2005). Cultura do medo e democracia: um paradoxo brasileiro. Mediações-Revista de Ciências Sociais, 10(2), 183-198.

Pastana, D. R. (2007). Os contornos do Estado punitivo no Brasil. Perspectivas: Revista de Ciências Sociais, 31 .

Pastana, D. R. (2012). Terrorismo, medo e recrudescimento do controle: traços da política punitiva no mundo contemporâneo. Mediações-Revista de Ciências Sociais, 16(2), 89-106.

Peres, M. F. T., \& Nery Filho, A. (2002). A doença mental no direito penal brasileiro: inimputabilidade, irresponsabilidade, periculosidade e medida de segurança. Hist Cienc Saude, 9(2), 335-55.

Pontalis, J. B., \& Laplanche, J. (2001). Vocabulário de psicanálise.Santos: Martins.

Prado, L. R. (2006). Curso de Direito Penal brasileiro: volume 1: Parte Geral-arts. $1^{o}$ a 120. rev., atual. e ampl. São Paulo: Editora Revista dos Tribunais.

Rossi, V. R. (2015). Medida de Segurança: a violação do direito à saúde a partir do conceito de periculosidade. CADERNOS IBERO-AMERICANOS DE DIREITO SANITÁRIO, 4(3), 75-93.

Roudinesco, E. (2008). A parte obscura de nós mesmos. São Paulo: Zahar.

Rovinski, S.L.R. \& Elgues, G.Z. (1999). Avaliação psicológica na área forense: uso de técnicas e instrumentos. Em: Anais do III Congresso Ibero-americano de Psicologia Jurídica, pg.361. São Paulo.

Rovinski, S.L.R. (2011). O Rorschach e as técnicas projetivas no contexto forense. In: A.E. de Villemor-Amaral \& B.S.G. Werlang (org.). Atualizações em Métodos Projetivos para Avaliação Psicológica (pp. 107-119). São Paulo: Casa do Psicólogo.

Safra, G. (2009). Alguns Princípios Fundamentais Subjacentes à Clínica Winnicottiana in Ferreira e outros, A Presença de Winnicott no Viver Criativa. Ed. ZY, São Paulo.

Saurí, J. J. (2001). O que é diagnosticar em psiquiatria. São Paulo: Escuta.

Szasz, T. S. (1974). O mito da doença mental. São Paulo: Círculo do Livro.

Semeraro, G. (2006). Intelectuais “orgânicos” em tempos de pós-modernidade. Cad. Cedes, Campinas, 26(70), 373-391. 
Shontz, F. C. \& Green, P. (1992). Trends in research in Rorschach: Review and recommendations. Applied and Preventive Psychology, 1, 149-156.

Sobrinho, S. F. (2014). A cultura do medo e as transgressões contemporâneas. Revista Direito, Estado e Sociedade, (27).

Tschirner, S. (2001). Self e Referências. Em: Outeiral, J., Hisada, S. \& Gabriades, R. Winnicott Seminários Paulistas. São Paulo: Casa do Psicólogo.

Vicentino, C., \& Dorigo, G. (2001). História para o ensino médio: história geral e do Brasil. Scipione.

Villemor-Amaral, A.E. \& Pasqualini-Casado, L.P. (2006). A cientificidade das técnicas projetivas em debate. Psico-USF,11, (2), 185-193, jul-dez.

Vilhena, J. D. (2002). A arquitetura da violência: reflexões acerca da violência e do poder na cultura. Cadernos de psicanálise, Rio de Janeiro, 18(21), 181-200.

Webster, C. D., Eaves, D., Douglas, K. S. \& Wintrup, A. (1995). The HCR-20 scheme: The assessment of dangerousness and risk. Vancouver: Simon Fraser University and British Columbia Forensic Psychiatric Services Commission.

Weiner, I. B. (2000). Princípios da Interpretação do Rorschach. São Paulo: Casa do Psicólogo.

Winnicott, C. (1978). DWW: uma reflexão. Em: Explorações psicanalíticas. Porto Alegre: Artes Médicas, 1994.

Winnicott, C., Shepherd, R. \& Davis, M. (1987). Introdução dos organizadores da obra. Em: Privação e Delinquência. São Paulo: Martins Fontes, 2005.

Winnicott, D. W. (1939). Agressão (Escrito para professores). Em: Privação e Delinquência. São Paulo: Martins Fontes, 2005.

Winnicott, D. W. (1939). Letter to the British Medical Journal. In: Privação e Delinquência. São Paulo: Martins Fontes, 2005.

Winnicott, D. W. (1945). A criança evacuada. Em: Privação e Delinquência. São Paulo: Martins Fontes, 2005.

Winnicott, D. W. (1945). De novo em casa. Em: Privação e Delinquência. São Paulo: Martins Fontes, 2005. 
Winnicott, D. W. (1945). Desenvolvimento emocional primitivo. Em: Textos Selecionados - da Pediatria à Psicanálise. Rio de Janeiro: Francisco Alves, 1993.

Winnicott, D. W. (1946). Alguns aspectos psicológicos da delinquência juvenil. Em: Privação e Delinquência. São Paulo: Martins Fontes, 2005.

Winnicott, D. W. (1947). Tratamento em regime residencial para crianças difíceis. Em: Privação e Delinquência. São Paulo: Martins Fontes, 2005.

Winnicott, D. W. (1948). Alojamentos para crianças em tempo de guerra e em tempo de paz. Em: Privação e Delinquência. São Paulo: Martins Fontes, 2005.

Winnicott, D. W. (1951). Objetos Transicionais e Fenômenos Transicionais. Em: O Brincar e a Realidade. Trad. José Octavio de Aguiar Abreu e Vanede Nobre. Rio de Janeiro: Imago, 1975.

Winnicott, D. W. (1956). A tendência anti-social. Em: Privação e Delinquência. São Paulo: Martins Fontes, 2005.

Winnicott, D. W. (1956). Preocupação materna primária. Em: Textos Selecionados da Pediatria à Psicanálise. Rio de Janeiro: Francisco Alves, 1993.

Winnicott, D. W. (1958). A capacidade para estar só. Em: O ambiente e os processos de maturação: Estudos sobre a teoria do desenvolvimento emocional. Porto Alegre: Artes Médicas, 1990.

Winnicott, D. W. (1958). Psychoanalysis and the sense of guilt. In: Psycho-Analysis and Contemporary Thought. London: Hogarth.

Winnicott, D. W. (1959). O destino do objeto transicional. Em: Explorações psicanalíticas. Porto Alegre: Artes Médicas, 1994.

Winnicott, D. W. (1960). Distorção do ego em termos de falso e verdadeiro self. Em: O ambiente e os processos de maturação: Estudos sobre a teoria do desenvolvimento emocional. Porto Alegre: Artes Médicas, 1990.

Winnicott, D. W. (1960). The theory of the parent-infant relationship. International Journal of Psychoanalysis, 41(6), 585-595.

Winnicott, D. W. (1963). Da dependência à Independência do desenvolvimento do indivíduo. Em: O ambiente e os processos de maturação: Estudos sobre a teoria do desenvolvimento emocional. Porto Alegre: Artes Médicas, 1990. 
Winnicott, D. W. (1963). O desenvolvimento da capacidade de envolvimento. Em: Privação e Delinquência. São Paulo: Martins Fontes, 2005.

Winnicott, D. W. (1963). O desenvolvimento da capacidade de se preocupar. Em: O ambiente e os processos de maturação: Estudos sobre a teoria do desenvolvimento emocional. Porto Alegre: Artes Médicas, 1990.

Winnicott, D. W. (1964). Raízes da agressão (Escrito para The Child, the Family and the Outside World). Em: Privação e Delinquência. São Paulo: Martins Fontes, 2005.

Winnicott, D. W. (1965). O conceito de trauma em relação ao desenvolvimento do indivíduo dentro da família. Em: Explorações psicanalíticas. Porto Alegre: Artes Médicas, 1994.

Winnicott, D. W. (1967). A localização da experiência cultural. Em: O Brincar e a Realidade. Trad. José Octavio de Aguiar Abreu e Vanede Nobre. Rio de Janeiro: Imago, 1975.

Winnicott, D. W. (1970). Individuação. Em: Explorações psicanalíticas. Porto Alegre: Artes Médicas, 1994.

Winnicott, D. W. (1986). A comunicação entre o bebê e a mãe e entre a mãe e o bebê, convergências e divergências. Em: Os Bebês e suas mães. São Paulo: Martins Fontes, 1994.

Yarochewsky, L. I. \& Silva C. T. (2013). Periculosidade criminal: conceito, tratamento e consequências. Percurso Acadêmico, 3(5), 22-34.

Zaluar, A. (1999). Um debate disperso: violência e crime no Brasil da redemocratização. São Paulo em perspectiva, 13(3), 3-17. 